$$
\text { DDE/OR/00033 - T753 }
$$

The Microbial Fate of Carbon in High-Latitude Seas:

\title{
Impact of the Microbial Loop on
}

Oceanic Uptake of $\mathrm{CO}_{2}$

by

Patricia L. Yager

A dissertation submitted in partial fulfillment of the requirements for the degree of

Doctor of Philosophy

University of Washington

1996

Approved by

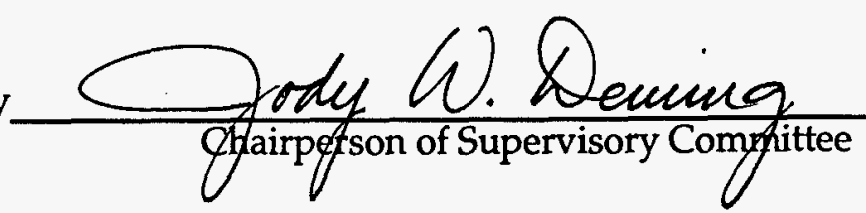

Program Authorized to Offer Degree School of Oceanography

Date Febuary 29, 1996

DISTRIBUTION OF THIS DOCUMENT IS UNLIMITED

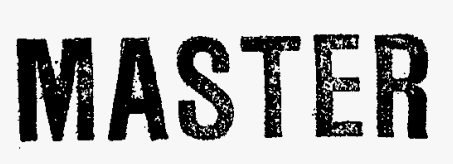




\section{DISCLAIMER}

This report was prepared as an account of work sponsored by an agency of the United States Government. Neither the United States Government nor any agency thereof, nor any of their employees, makes any warranty, express or implied, or assumes any legal liability or responsibility for the accuracy, completeness, or usefulness of any information, apparatus, product, or process disclosed, or represents that its use would not infringe privately owned rights. Reference herein to any specific commercial product, process, or service by trade name, trademark, manufacturer, or otherwise does not necessarily constitute or imply its endorsement, recommendation, or favoring by the United States Government or any agency thereof. The views and opirions of authors expressed herein do not necessarily state or reflect those of the United States Government or any agency thereof. 
The Goverment reserves for itself and others acting on its behalf a royalty free, nonexclusive, irrevocable, world-wide

license for govermental purposes to publish, distribute, translate, duplicate, exhibit, and perform any such data copyrighted by

the contractor. 
In presenting this dissertation in partial fulfillment of the requirements for the Doctoral degree at the University of Washington, I agree that the Library shall make its copies freely available for inspection. I further agree that extensive copying of this dissertation is allowable only for scholarly purposes, consistent with "fair use" as prescribed in the U.S. Copyright Law. Requests for copying or reproduction of this dissertation may be referred to University Microfilms, 1490 Eisenhower Place, P.O. Box 975, Ann Arbor, MI 48106, to whom the author has granted "the right to reproduce and sell (a) copies of the manuscript in microfom and/or (b) printed copies of the manuscript made from microform."

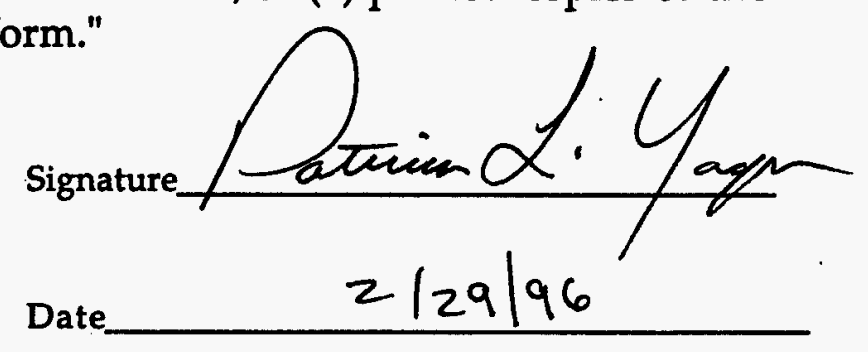




\title{
UNIVERSITY OF WASHINGTON
}

\begin{abstract}
The Microbial Fate of Carbon in High-Latitude Seas: Impact of the Microbial Loop on Oceanic Uptake of $\mathrm{CO}_{2}$ by Patricia L. Yager
\end{abstract}

Chairperson of the Supervisory Committee: Professor Jody W. Deming School of Oceanography

This dissertation examines pelagic microbial processes in high-latitude seas, how they affect regional and global carbon cycling, and how they might respond to hypothesized changes in climate. Critical to these interests is the effect of cold temperature on bacterial activity. Also important is the extent to which marine biological processes in general impact the inorganic carbon cycle. The study area is the Northeast Water (NEW) Polynya, a seasonallyrecurrent opening in the permanent ice situated over the northeastern Greenland continental shelf. This work was part of an international, multidisciplinary research project studying carbon cycling in the coastal Arctic.

The first chapter describes a simple model which links a complex marine food web to a simplified ocean and atmosphere. This model is designed to test the sensitivity of the air-sea flux of carbon to microbial food web structure and behavior, particularly those processes which might be sensitive to warming. Preliminary results suggest that organisms can impact short term air-sea carbon flux. 
The second chapter investigates the inorganic carbon inventory of the summertime NEW Polynya surface waters to establish the effect of biological processes on the air-sea $\mathrm{PCO}_{2}$ gradient. A unique one-way sink for atmospheric carbon is hypothesized for the NEW Polynya and other seasonally-ice-covered seas. If this type of one-way carbon sink occurs on a global scale, it may provide a significant feedback to greenhouse warming.

The third and fourth chapters use a kinetic approach to examine microbial activities in the NEW Polynya as a function of temperature and dissolved organic substrate concentration, testing the so-called "Pomeroy hypothesis" that microbial activity is disproportionately reduced at low environmental temperatures owing to increased organic substrate requirements. With field experiments, responsive microbial communities of mostly psychrophilic (cold-loving) organisms were often found to exhibit high affinities to and high incorporation efficiencies on nitrogen-rich organic matter; their response to temperature was heterogeneous, however, indicating that controls on microbial behavior may not be as simple as previously believed. Together, the suite of data collected on microbial activities, cell 'size, and grazing pressure suggest how unique survival strategies adopted by an active population of high-latitude bacteria may contribute to, rather than detract from, an efficient biological carbon pump. 


\section{TABLE OF CONTENTS}

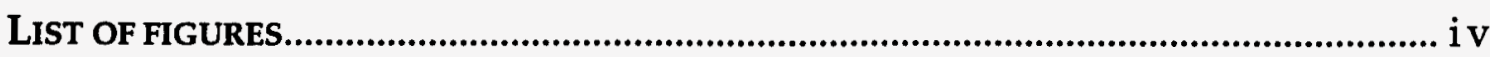

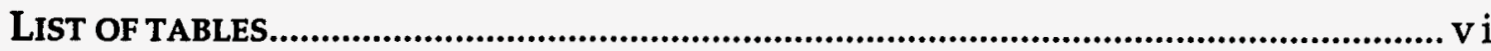

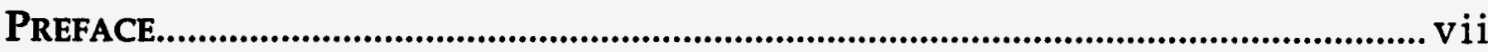

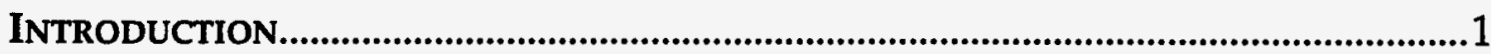

Air-sea carbon flux and the role of marine ecosystems .................................. 1

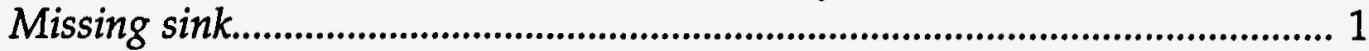

Modeling assumptions................................................................................... 1

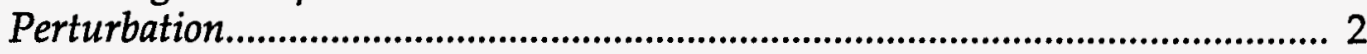

High-latitude coastal ecosystem............................................................................... 3

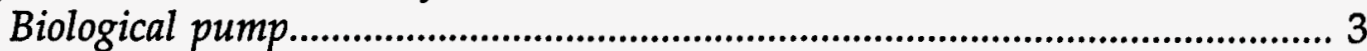

The Northeast Water (NEW) Polynya......................................................... 4

Rectification Hypothesis........................................................................................ 4

Temperature effects on microbial activity: optimal foraging and survival strategies ................................................................................................ 6

Cold adaptations ..................................................................................................... 6

"Pomeroy Hypothesis" ......................................................................................... 7

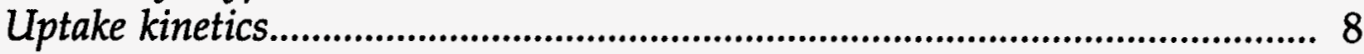

Incorporation efficiency.............................................................................. 9

Research goals......................................................................................................... 10

I. MODELING THE IMPACT OF MARINE ECOSYSTEMS

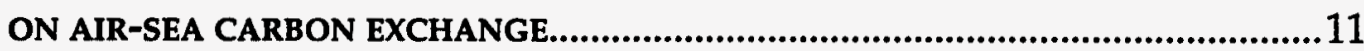

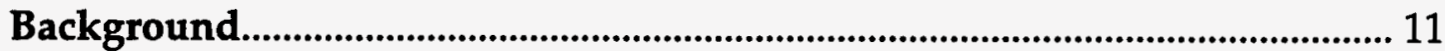

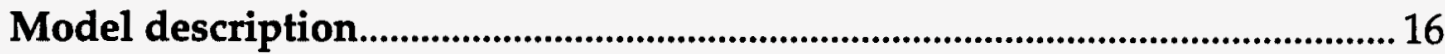

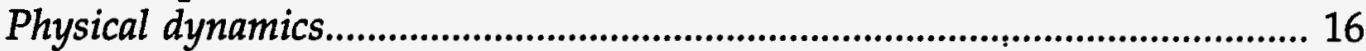

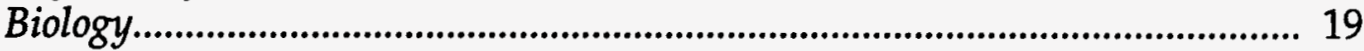

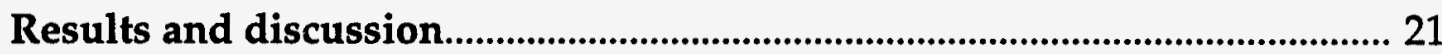

Standard model time series.....................................................................21

Standard model depth profiles................................................................... 26

Sensitivity experiments........................................................................................ 27

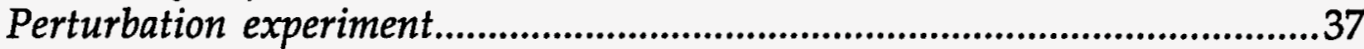

Conclusions and future plans for model................................................................ 44 
- Reprint-removed for sepanate processing

II. The Northeast Water Polynya as an atMospheric $\mathrm{CO}_{2}$ SINK:

A SEASONAL RECTIFICATION HYPOTHESIS ..................................................47

Abstract

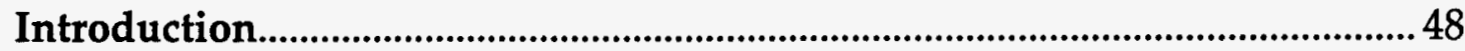

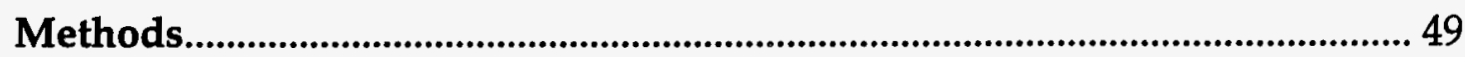

Sampling technique and analysis.................................................................. 49

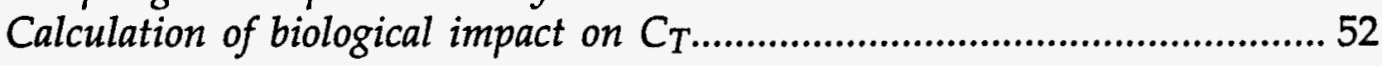

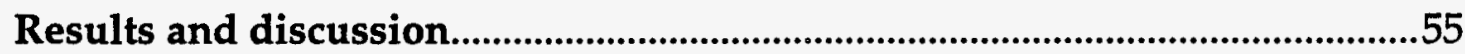

Physical and chemical processes................................................................. 55

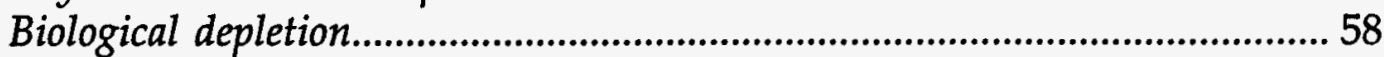

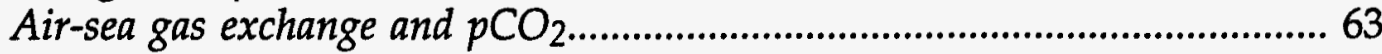

Rectification Hypothesis....................................................................................... 67

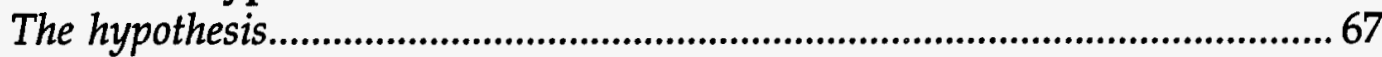

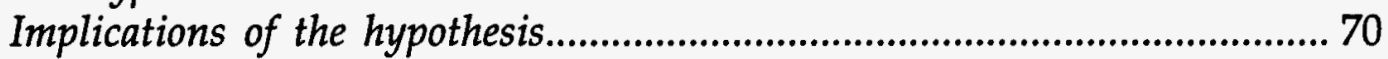

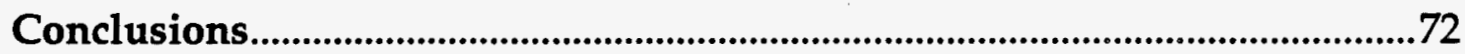

\section{Pelagic microbial activity in the Northeast Water Polynya:}

TESTING FOR TEMPERATURE AND SUBSTRATE INTERACTIONS

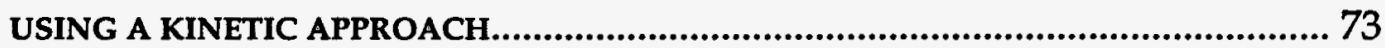

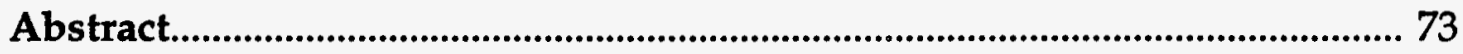

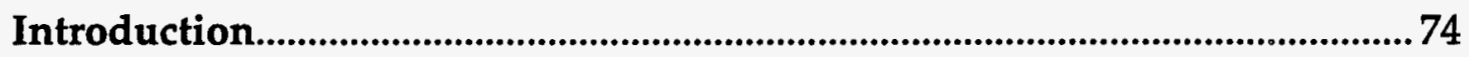

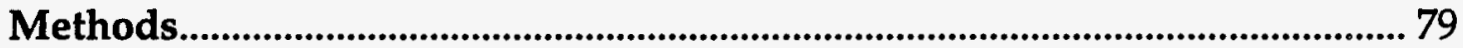

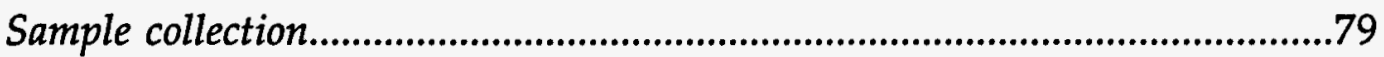

Substrate availability........................................................................................ 79

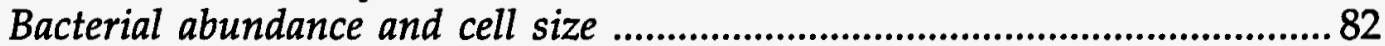

Potential growth rates........................................................................................ 83

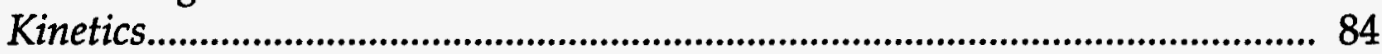

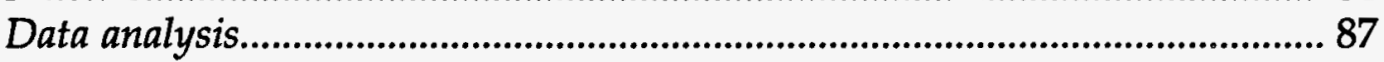

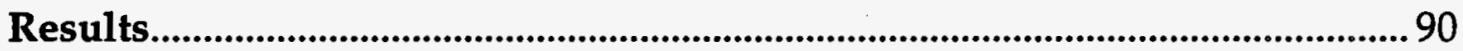

Substrate availability...................................................................................... 90

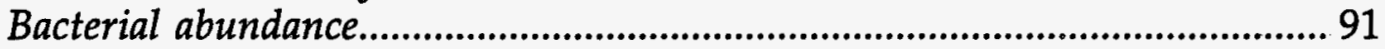

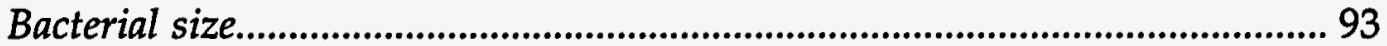

Potential growth rates....................................................................................... 94

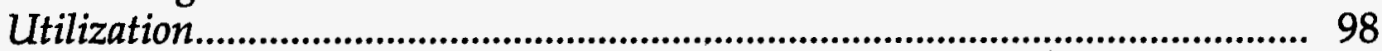

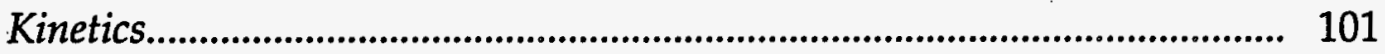

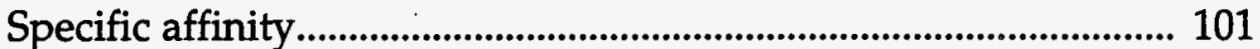

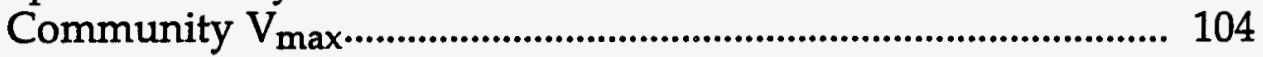

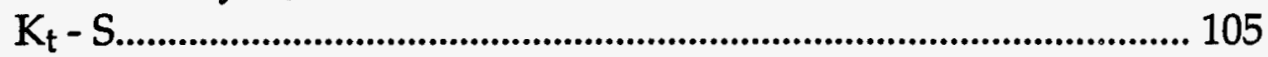

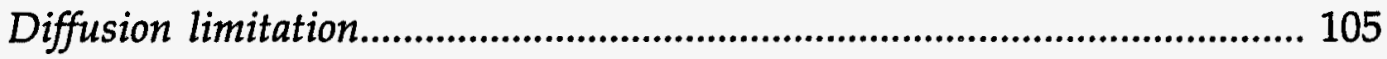




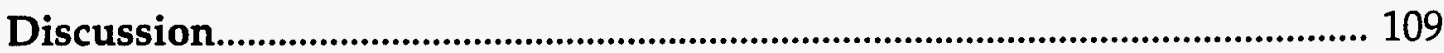

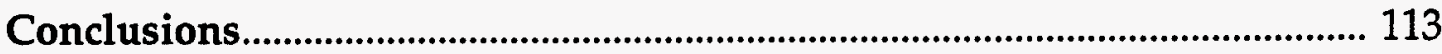

IV. Pelagic microbial efficiency in the Northeast Water Polynya: IMPLICATIONS FOR INORGANIC CARBON CYCLING

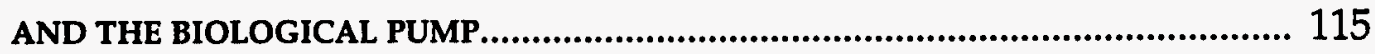

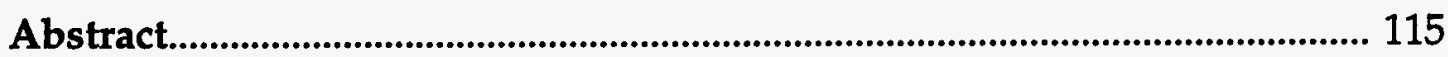

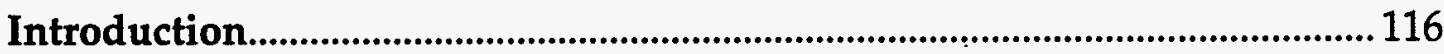

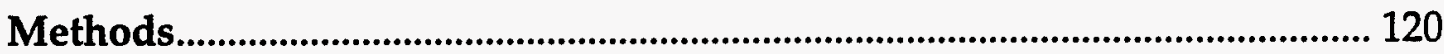

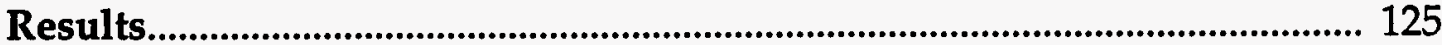

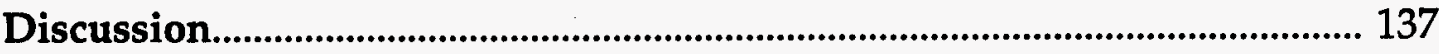

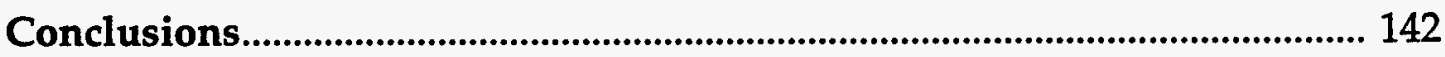

V. OVERALL CONCLUSIONS AND FUTURE RESEARCH PLANS ................................... 143

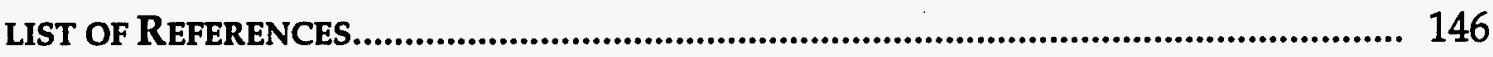

APPENDIX 1: DERIVATION OF EQUATION III-1 ..................................................... 170 


\section{LIST OF Figures}

A-1 Map of the Northeast Water Polynya. 5

I-1 The dynamical model. 17

I-2 Input functions for the dynamical model as a function of time. 18

I-3 The biological model. $\quad 20$

I-4 Light forcing functions. 24

I-5 Standard Model results as a function of time. 28

I-6 Standard Model results as a function of depth. 30

I-7 Model results from increased grazing rate (Expt. \#1). 32

I-8 Model results from increased bacterial efficiency (Expt. \#2). $\quad 34$

I-9 Model results from aggregation effect (Expt. \#3). 38

I-10 Model results from increased zooplankton efficiency (Expt. \#4). 40

I-11 Comparison of model results for annual carbon flux. 42

I-12 Model generated oceanic uptake of anthropogenic $\mathrm{pCO}_{2}$. 43

II-1 Topographic map of the study site showing sampling locations. $\quad 50$

II-2 Total dissolved inorganic carbon profiles for all stations and 56 salinity-scaled $\mathrm{C}_{\mathrm{T}}$ scaled to salinity compared to $\mathrm{A}_{\mathrm{T}}$.

II-3 Biologically mediated inorganic carbon deficit (B) as a function 60 of integrated POC and salinity-scaled dissolved inorganic nitrogen deficit.

II-4 Model results for time required to replenish B as a function of wind speed.

II-5 Wind speed data from Danmarkshavn during September 1991. 66

II-6 Proposed annual cycle of biological and physical processes. 68

III-1 Map of the NEW Polynya with station locations for 80 microbiological experiments.

III-2 Plot of $\log 10$ chlorophyll $a$ versus $\log 10$ bacterial abundance. 92

III-3 Encounter rate as a function of prey diameter. 95

III-4 Potential bacterial growth rates as a function of temperature. 96

III-5 Utilization of 14C-amino acids as a function of time. 99 
III-6 Distance weighted least squares surface fits to utilization rates as a function of added substrate concentration and incubation temperature.

III-7 Dimensionless ratio $\left(P^{*}\right)$ as a function of the percentage of active cells.

IV-1 Map of NEW Polynya region with microbiological stations.

IV-2 Mass-balance flow chart for polynya bacteria with methods.

IV-3 Incorporation efficiency versus utilization rate for $10 \mathrm{nM}$ leucine, mixed amino acids, glucose, and glutamic acid additions.

IV-4 Three-dimensional surface plots of percent respiration versus temperature and added substrate concentration.

IV-5 Bacterial production (BP-LEU) as a function of primary . production.

IV-6 Bacterial production (BP-LEU) as a function of BP-TDR.

IV-7 Grazing rate as a function of bacterial growth.

IV-8 Average bacterial growth and bacterivory for stations subdivided by ecosystem type.

IV-9 Mass-balance figure redrawn with proportional arrows 


\section{LIST OF TABLES}

Page

I-1 Parameters used in models and their assigned values. 22

II-1 NEW Polynya stations with associated inorganic carbon data. 51

III-1 NEW Polynya station information for microbiological 81 samples.

III-2 Results of M(ANOVA) test for effects on utilization rate. 100

III-3 Specific affinity as a function of incubation temperature (T). 106

III-4 Vmax and Kt-S as a function of incubation temperature (T). 107

IV-1 M(ANOVA) results for incorporation efficiency. 128 


\section{Preface}

". . . the professional duty of a scientist confronted with a new and exciting theory is to try to prove it wrong. That is the way science works. That is the way science stays honest. Every new theory has to fight for its existence against intense and often bitter criticism. Most new theories turn out to be wrong, and the criticism is absolutely necessary to clear them away and make room for better theories. The rare theory which survives criticism is strengthened and improved by it, and then becomes gradually incorporated into the growing body of scientific knowledge."

-F. Dyson (1988) from Infinite in All Directions 


\section{ACKNOWLEDgments}

Words do not well express the sincere appreciation and admiration that I have for my advisor, Dr. Jody Deming. Her faith and encouragement provided a world where I could safely develop the strength to trust myself and my ideas; her scientific vision and leadership provided a framework on which those ideas could grow; her constructive editing skills helped me learn how to express them. Thanks to Jody, I understand the meaning of the word Mentor.

My supervisory committee provided important stepping stones along the way, often in the form of courses they taught: Dr. John Baross first turned my head towards Microbiology with intriguing stories about marine bacteria and then never ceased to inspire me with his own curiosity; Dr. Steve Emerson kindled an interest in geochemistry and then gave me the tools to explore it and also to think critically about my ideas; Dr. Richard Gammon inspired me to think globally and develop the model presented in Chapter 1; Dr. Evelyn Lessard introduced me to the wonderful world of protozoa and also assisted with data analysis at a critical time; and Dr. Barbara KriegerBrockett provided a new spin on science, data analysis, and statistics, as well as a much needed check on jargon. I am grateful for their significant contributions to my research and to this dissertation.

I was fortunate to be supported financially throughout my entire Ph.D. program by a Department of Energy Graduate Fellowship for Global Change Research. This program, administered at the Oak Ridge Institute for Science and Education by Milton Constantin and Mary Kinney (Science/Engineering Education Division), provided a secure and supportive environment that allowed me to stay focused on my research. The Research Practicum requirement was pivotal in spawning my collaboration with Doug Wallace at Brookhaven National Laboratories and producing the data presented in Ch. 2. 
The National Science Foundation also provided financial support to my advisor, Jody Deming, as part of the ARCSS multidisciplinary investigation of the Northeast Water Polynya. This grant enabled me to go to sea and collect the data presented in Chapters 2, 3, and 4 of this dissertation, as well as to attend several valuable planning and data workshops with the other NEWP investigators. I was very fortunate to be a part of the scientific team for the NEW Polynya project. This inspirational group of scientists treated me as a colleague, rather than an underling, and contributed greatly to my scientific development. I am particularly grateful to Doug Wallace for his synergistic collaboration on Ch. 2. Walker Smith and Peter Minnett provided supporting data and were also co-authors on the published version of Ch. 2 .

I am greatly indebted Dr. Katharina Kurz Six ("Tinka") who showed open-mindedness to my wild ideas and patience in teaching me how to use models as tools. With great optimism and with the good-natured push-mepull-you compromises required for a carbon modeler and a microbiologist to work together, Tinka and I initiated what I hope are long careers working together to find answers to all those questions we asked during the Summer of 1991.

Any talent for analytical chemistry that may appear on these pages is due to the patient tutelage of Doug Wallace, Ken Johnson (who designed the SOMMA instrument I used to measure total inorganic carbon in Ch. 2), Rick Wilke (who showed me how to take apart and then rebuild a functioning SOMMA), Dr. Catherine Goyet (who provided generous guidance as well as access to her alkalinity titration system), Maren Tracey and Bob Adams (who provided technical support with the titrator).

I am grateful to the captains, officers, and crew of both the US Coast Guard Cutter Polar Sea and the German research vessel Polarstern for getting us both into and out of the polynya safely and successfully. 
My early-season experience in the polynya, so pivotal in the development of the Rectification Hypothesis, would not have been possible without the generous invitation by Dr. Kim Juniper and the collaboration of Dr. Telesphore Sime-Ngando. On board Polarstern, assistance and invaluable support came from Dr. Michel Gosselin, Stéphane Pesant, Paul Renaud, Annelie Skoog, and Kendra Daly. The birthday polar bear was a nice touch.

On board Polar Sea, and in the Deming Lab in Seattle, I could not have managed all of the data collection without the good-natured assistance of Shelly Carpenter, Jan Gaylord, Charles Maples, and John Murray. Thank you for all the washed bottles, the folded wicks, the millions of counted bacteria, and also for the moral support when I needed it the most. Jody's other graduate students: Yves-Alain Vetter, Michelle Bieniek, and Jill Schmidt, and the Baross group: Jim Holden, Melanie Summit, Byron Crump, and Jon Kaye also provided valuable feedback (or chocolate) along the way.

My office mates often played the critical role of sounding board when I needed to sit back in my chair and think outloud. To Deborah Penry, Amy Abbot, Melanie Summit, and Jon Kaye: thanks for listening. Deborah gets additional thanks for originally recommending me to Jody.

I was very fortunate to spend time with Drs. Pomeroy, Hodson, Wiebe, and Moran at the University of Georgia. Their influence on my research during the first months of this project was critical to the design my field program. I look forward to working with them during the coming year. I also thank Dr. John Imbrie at Brown University for introducing me to the profession of Oceanography.

Arthur Nowell and Peter Jumars have been stalwart supporters of me and my research for longer than I care to remember, and often despite my own uncertainty. I will always be indebted to them for the strong influence they had on my scientific approach and for the faith they never lost. 
Friends and family made a huge difference in my graduate student life. I was blessed to have wonderful housemates who have become lifelong friends: Liz, Susan, Gabrielle, Jessica, and Mary. Sunday dinners at Mom and Dad's also provided weekly physical and emotional sustenance during the rough seas of graduate school. All the other friends and family who touched my life, please know you had a great influence on the final outcome of this project. "It takes a village..."

I am thankful that during the final stages of this project, my partner in life and in science, Steven Holland, realized at last how much of an influence he has had on me and my research. He is my rock, my anchor, the ladder to my castles in the sky, and my love, forever and always. 


\section{DEDICATION}

This dissertation is dedicated to all the women who walked before and beside me, leaving enough footprints to reveal that not all paths nor ideas are linear.

Jody Deming, Barbara Krieger-Brockett, Evelyn Lessard, Mary Jane Perry, Susan Hautala,

Elizabeth Fortenbery,

Deborah Penry,

Anna Louise Reysenbach,

Ann Russell,

Tinka Kurz Six,

Amy Abbot,

Gabrielle Toutonghi,

Jessica Marks,

Shelly Carpenter, Jan Gaylord,

Laura Landrum,

Mary Culver,

Colin Roesler,

Monie Naidoo,

Kendra Daly,

Carin Ashjian,

Lisa Clough,

Marina Yong,

Mary Ann Moran,

Melanie Summit,

Rita Horner,

Beatrice Booth,

DeirdreMurphyYager, LureneDavis Yager, Sylvia Parmenter Otis, JanetOtis Yager 


\section{INTRODUCTION}

\section{Air-sea carbon flux and the role of marine ecosystems}

Missing sink. The striking feature of nearly all global carbon-cycle models is their inability to match the observed atmospheric increase in $\mathrm{pCO}_{2}$ with the larger anthropogenic source. One aspect of my research focuses on the extent that marine ecosystems, particularly at high latitudes, could be part of the as yet unaccounted for (missing) carbon sink. Although the marine biosphere is considered a relatively small reservoir of carbon in the global scheme (3 Gt C; Siegenthaler and Sarmiento, 1993), the relative flux of carbon through this reservoir $\left(>300 \% \mathrm{yr}^{-1}\right)$ is by far the greatest of all pools in the system, providing the greatest potential for feedback.

Modeling assumptions. One reason for underestimating the air-to-sea carbon flux and the role of marine biota may be the coarse resolution of existing models, not only in space but also in time. Biological processes are often patchy as well as cyclic or episodic. As a result, annual or even seasonal time-stepping by models can underestimate the biological effect. Existing global carbon models are also incomplete in their parameterization of recycling (e.g. Armstrong, 1994; Najjar et al., 1992; Sarmiento et al., 1989). These models assume steady state and emphasize new production that results from the utilization of "preformed" or "new" nutrients (from upwelling, atmospheric deposition, or in situ N-fixation; Redfield et al., 1963). In this scenario, new production equals export production (Eppley and Peterson, 1979) according to a constant stoichiometry (Redfield et al., 1963), and only new production plays a significant role in the sequestration of carbon. 
My approach has been to query the assumption that the processes of carbon export function at steady state, coupled spatially and temporally to nitrogen cycling, with constant Redfield ratios. I use a type of sensitivity analysis which purposefully incorporates episodicity and biological variation to test for biological influence on short- and long-term air-sea carbon exchange. Chapter 1 of this dissertation discusses these ideas further and introduces the first results from an ongoing modeling exercise designed to determine the extent to which complex microbial processes can influence carbon flux in the ocean.

Perturbation. Also of interest is whether marine biota can impact anthropogenic carbon dioxide (Broecker, 1991; Smith and Mackenzie, 1991) or affect global climate change on longer time scales. The critical issues of global change research, particularly in biological oceanography, are concerned with how and at what rate a system which may or may not be in steady state responds to perturbation. In order for a physical, chemical, or biological system to be a sink for anthropogenic $\mathrm{CO}_{2}$, the flux of carbon related to that system must have increased relative to its pre-perturbation value (Smith and Mackenzie, 1991). Though it would be much simpler to assume that biological processes have been and always will be the same as observed today, there is no reason to believe that biological systems will not respond to significant changes in their physical or chemical environment, particularly when temperature is involved. Changes in ultraviolet (UV) radiation exposure is also likely to have an influence on biological processes.

Microbiological processes may be especially important in perturbation scenarios for several reasons. They occur over a large range of temporal and 
spatial scales, and only occasionally is it safe to assume steady state. Bacteria play an active if not primary role in every ecosystem on the planet through the global cycling of carbon, nitrogen, and other biogeochemically important elements. Of all the biological systems, bacteria are the best equipped physiologically and genetically to respond quickly to change.

This dissertation illustrates in several ways how ecosystems potentially impact the oceanic uptake of anthropogenic carbon: (1) via episodicity (nonsteady state processes); (2) via ice cover and its effect as a wintertime lid to outgassing, and (3) via temperature effects on microbes (rates or efficiencies sensitive to warming).

\section{High-latitude coastal ecosystems}

Biological pump. One of the regions where global climate changes are expected to have the greatest impact is the high latitudes (Hansen et al., 1984). High-latitude oceans are also unique and critical to the global carbon cycle for several reasons, including strongly seasonal, short-term but high rates of biological productivity and the formation of deep water (Knox and McElroy, 1984; Sarmiento and Toggweiler, 1984; Siegenthaler and Wenk, 1984). The geochemical model of Knox and McElroy (1984) shows how the "efficiency of the biological pump" (which depends inversely on the extent of remineralization) in high-latitude seas significantly determines the degree to which carbon is sequestered in the global deep sea. Coastal arctic ecosystems are among the most productive in the world, with spatial and temporal heterogeneity as common characteristics. Seasonally ice-covered regions such as marginal ice zones and some polynyas are sites where the strong influences of light, nutrients, and temperature merge to create short-term but dramatic 
blooms which can occur rapidly (Smith et al., 1991; Sullivan et al., 1988). In an environment characterized by strong localized pulses of primary production, the response of microorganisms within the euphotic zone may determine the rate of carbon, nitrogen, and phosphate remineralization and also the fraction of total production that is exported from the euphotic zone (Wiebe and Pomeroy, 1991).

The Northeast Water (NEW) Polynya. The NEW Polynya was the study area for an intensive, multi-disciplinary research project investigating biogeochemical cycling in high-latitude oceans in 1992 and 1993 (NEWater Investigators, 1993; Overland et al., 1995; Hirche and Deming, in press). The polynya is a seasonally-recurrent opening in the permanent ice situated over the continental shelf of northeastern Greenland $\left(77-81^{\circ} \mathrm{N}, 6-17^{\circ} \mathrm{W}\right.$; Fig. A-1). Typically the ice begins to open in May and close in October. Ice algal blooms dominate primary production early in the season, while phytoplankton blooms (mostly diatoms) develop later. Because of the heterogeneity in the summertime ice coverage, however, all stages of this succession may be present in the polynya at any one time. I participated in research cruises to this region in July-August 1992, May-June 1993, and July-August 1993.

Rectification Hypothesis. Seasonally ice-covered seas at high latitudes may be potential one-way (rectified) sinks for atmospheric carbon, driven by a unique linkage between strongly seasonal biological productivity and sea-ice formation (Ch. 2; Yager et al., 1995). This scenario is sensitive to climate change because of the predicted increase in the areal extent of these regions due to global warming (Ingram et al., 1989) and provides a negative feedback to increasing anthropogenic $\mathrm{CO}_{2}$. The rectification scenario, however, also 


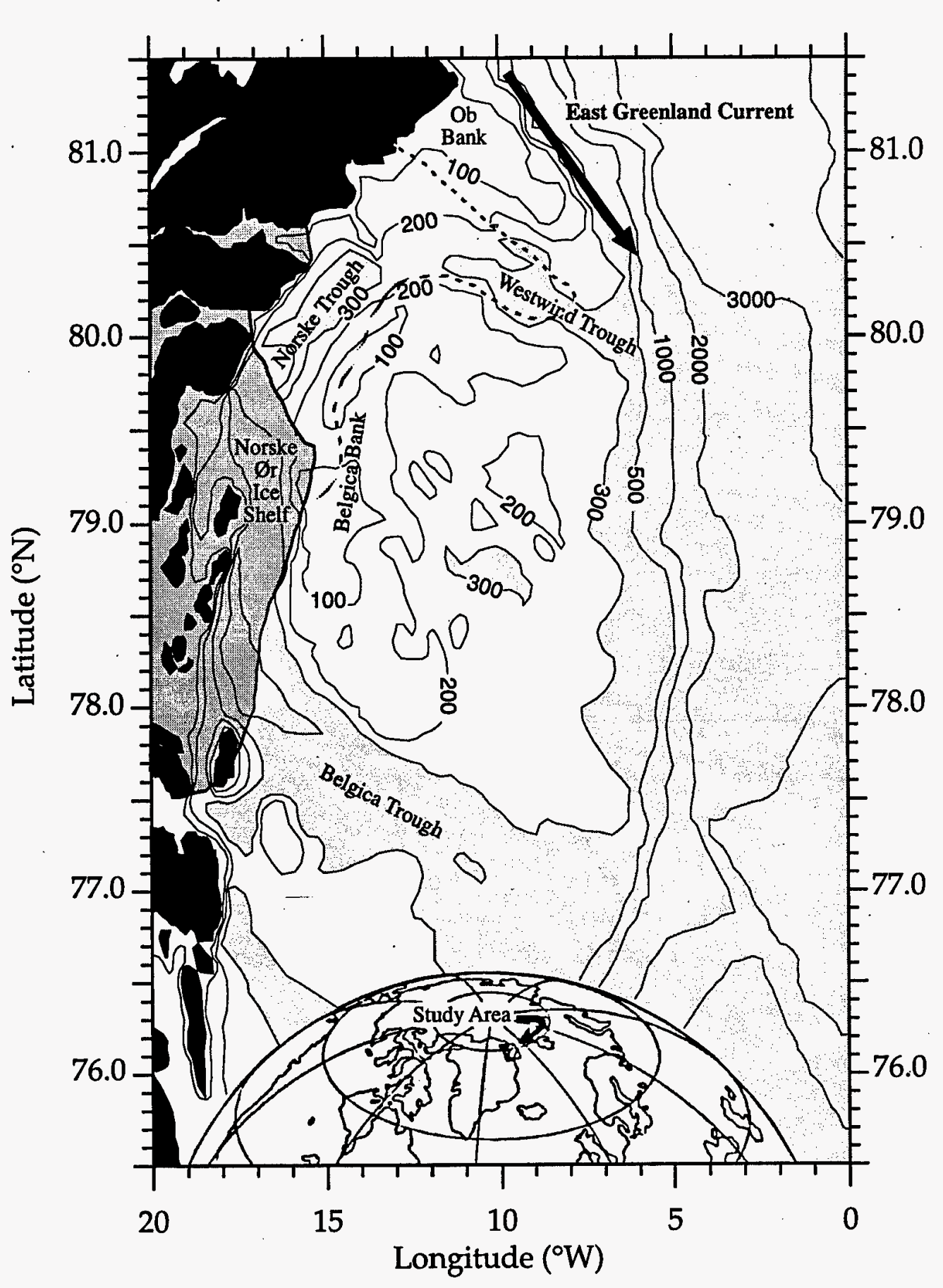

Figure A-1. Map of the Northeast Water (NEW) Polynya showing bathymetry (depth contours in meters), geographic features, and maximum extent of open water during August 1992 (dashed line; polynya opened north of Norske $\varnothing$ r Ice Shelf, over Norske Trough region). 
depends on low pelagic respiration rates during summer which allow primary production to undersaturate inorganic carbon in the surface waters. It further assumes that biological activity will remain the same if highlatitude oceans warm. This may not be a reasonable expectation since many of the marine biota in these regions have adapted to a narrow range in temperature and may show especially strong sensitivity to warming (Baross and Morita, 1978). I investigate this idea in Chapters 3 and 4.

Temperature effects on microbial activity: optimal foraging and survival strategies

Cold adaptations. Unlike in the temperate or tropical surface ocean, pulse-responsive bacteria in polar oceans must also be cold-adapted (i.e. able to respond quickly to a food source while living at sub-zero temperatures). Prevailing wisdom suggests that most organisms operate very slowly when they are cold. Yet, slow organisms, designed for a steady food supply, seem illsuited for the dynamic polar environment. This apparent contradiction has been one of the underlying themes of my research, directing my focus toward those organisms that seem to do best, by some measure, at low temperature. Psychrophilic (cold-loving) bacteria have been studied in the laboratory for decades and, while I do not review that literature here (see for example recent reviews by Russell, 1990, Gounot, 1991, and Karl, 1993, and references therein, especially earlier reviews of Baross and Morita, 1978, and Morita, 1966, 1975), there are indications that strategies for survival and definitions of optimality may be fundamentally different from those we consider standard in the temperate environment. The same case can be made for organisms living in especially low-nutrient environments, or oligotrophs (see reviews by Morgan 
and Dow, 1986, or Fry, 1990). During my dissertation research, I developed a sense that these two types of "extreme" environments, and the constraints on organisms associated with them, probably come together in the coastal Arctic, much like they do in the deep sea (Deming, 1986, who suggested a link between oligotrophy and barophily). While there are times in the polar spring and summer when phytoplankton bloom and dissolved organics may become readily available (either directly or via grazing), the most common condition in these permanently cold environments is probably low organic nutrients. As a consequence, the most competitive organism might have a rapid response to high nutrient pulses, but overall a greater tendency for storage (Amy et al., 1983) and low endogenous metabolism (e.g., more active and/or efficient respiratory chain, lower energy of maintenance, and lower minimal growth rate; Morgan and Dow, 1986). Transport systems that capture the ephemeral food supply must be constitutive, i.e., always ready (Koch, 1979), but catabolic enzymes that utilize specific substrates should be sensitive to available substrate concentrations (Novitsky and Morita, 1977; Harder and Dijkhuizen, 1983). There also appear to be advantages in being a generalist (Button, 1994).

"Pomeroy Hypothesis." The link between temperature and substrate concentration lies at the center of the polar microbial activity debate. At issue is whether bacteria in permanently cold $\left(<5^{\circ}\right)$ waters respond differently to pulses of substrates than do bacteria in permanently or seasonally warm water. The initial results of Pomeroy and co-workers (Pomeroy and Deibel, 1986; Pomeroy et al., 1990, 1991; Wiebe et al., 1992, 1993) suggest that the microbial community in northern high-latitude seas require relatively high 
concentrations of organic matter at low temperatures. These greater food requirements might result in an under-utilization of primary production and thus provide a greater chance for carbon export (Pomeroy and Wiebe, 1988). Recent laboratory work with cultured psychrophilic bacteria (Pomeroy et al., 1995), however, show a heterogeneous response to organic nutrient concentration and suggest that the situation may be more complicated than originally thought. This project examined temperature and substrate effects on bacterial utilization and incorporation efficiency, directly testing the Pomeroy hypothesis for its application in the NEW Polynya.

Uptake kinetics. Bacteria in low-nutrient or pulsed-nutrient environments can increase their potential uptake of substrate in two ways: by increasing the number of binding proteins on the cell surface (thereby increasing their maximum specific uptake rate, $V_{\max }$ ), or by synthesizing a binding protein with a greater affinity for substrate (thereby lowering the halfsaturation constant, $K_{m}$; Matin and Veldkamp, 1978). ANT-300, a psychrophilic marine Vibrio from Antarctic waters, has at least two transport systems with different affinities for arginine (Geesey and Morita, 1979). Some bacteria from low nutrient environments have more affine amino acid transport systems than their copiotrophic counterparts (Ishida et al., 1982).

Button $(1985 ; 1991 ; 1994)$ argues that $V_{\max }$ and $K_{m}$ are not independent and that the specific affinity for a substrate ( $a_{A}^{0} ;$ initial slope of the hyperbolic response curve) better reflects nutrient collection ability. All three of these parameters can be estimated using radiolabeled substrate additions to natural samples or cultured populations. Chapter 3 discusses how I measured these three parameters as a function of temperature using short term incubations of 
natural communities from the NEW Polynya. Although there are limitations to using the kinetics approach in the marine environment (see for example the discussion in Karl, 1986), it is still the most direct means of addressing how bacteria direct their food capture and utilization mechanisms to survive and perhaps even thrive in cold, nutrient-limited environments.

Incorporation efficiency. In an environment were the food supply is often scarce, it makes sense for organisms to use the energy wisely. Deming and Yager (1992) suggested that polar deep-sea sediment bacteria may show uniquely high incorporation efficiencies on certain organic substrates. My dissertation research has further investigated and confirmed this phenomenon for the NEW Polynya surface waters (Ch. 4). The metabolic pathway of dissolved organic carbon taken up by heterotrophic bacteria can vary according to the quantity and type of compounds available (Goldman et al., 1987). Griffiths et al. (1984; 1978) report respiration efficiencies for the Beaufort Sea which depend on substrate type, temperature, and also on the season. Growth efficiency in protozoa (e.g., bacterivores) can depend on the physiological state of the cell (Fenchel and Finlay, 1983) and temperature (Choi and Peters, 1992). I also found that efficiency sometimes depends on temperature (decreasing with warming) and organic substrate concentration (decreasing with increasing food). These results have implications for both global biogeochemistry and microbial ecophysiology which are discussed at the end of chapter 4 and in the final conclusions of the dissertation.

Extreme environments (from a temperate-living human point of view) provide unique opportunities for examining adaptation or optimal foraging behaviors in microorganisms. In any discussion of adaptation, one 
must be certain to frame the question properly with respect to the organism (Stephens and Krebs, 1986). Fitness depends on the time-scales over which it is measured and the currency used in its evaluation. An optimal strategy for cold-adapted bacteria may incorporate other constraints such as food supply and grazing pressure. In some cases, stability rather than maximization may be optimal (Maynard Smith, 1982; Stephens and Krebs, 1986).

\section{Research goals}

My research project set forth the following five goals: (1) determine with modeling whether biology, through non-steady state processes, could potentially impact the air-sea flux of carbon; (2) establish the extent of biological impact on the seasonal and annual inorganic carbon cycle in the present-day NEW Polynya, using it as a model system for seasonally icecovered high-latitude oceans; (3) determine the role of pelagic bacteria in the carbon cycle of the NEW Polynya region; (4) determine the sensitivity of this role to temperature; and (5) predict the sensitivity and feedback response of the high-latitude oceanic carbon cycle to expected warming. 


\title{
I. Modeling the Impact of MARINe Ecosystems
}

\author{
on Air-Sea Carbon Exchange.
}

\section{Background}

During the summer of 1991, while participating in a course on Climate and the Marine Biosphere at Friday Harbor Marine Laboratories, Katharina Kurz Six (Max Plank Institut für Meteorology, Hamburg, Germany) and I built a model designed to test the then-prevailing idea that marine biological processes did not have any influence over the oceanic uptake of anthropogenic $\mathrm{CO}_{2}$ (Broecker, 1991). We began by noting that existing global carbon cycle models were unable to match the observed atmospheric increase in $\mathrm{PCO}_{2}$ with the well-known anthropogenic source function (recently discussed by Siegenthaler and Sarmiento, 1993). Tans et al. (1990) proposed that the missing sink had to be in the northern hemisphere and that it was probably the extensive northern forests. Having recently read the three classic box models that revealed the importance of high latitude oceans in controlling atmospheric $\mathrm{pCO}_{2}$ levels over glacial-interglacial time scales (Knox and McElroy, 1984; Sarmiento and Toggweiler, 1984; Siegenthaler and Wenk, 1984), my first thought was that some of the missing sink could be in the Arctic ocean, assisted by the unique marine biota of the high-latitude continental shelves, particularly if the high-latitude community was responsive to temperature changes and thus to the anthropogenic perturbation. This idea was not entirely inconsistent with the Tans et al. (1990) analysis, since they grouped all oceanic data north of $50^{\circ} \mathrm{N}$ latitude; the 
12

average $\triangle \mathrm{pCO} 2$ used $(-37 \mathrm{ppm})$ to estimate air-sea flux for northern oceans was certainly an underestimate for some regions of the Arctic (see Chapter 2).

Biological processes were essentially ignored in most of the oceanic geochemical models built during the late 1980's and early 1990's (e.g., Bacastow and Maier-Reimer, 1990; Maier-Reimer and Hasselmann, 1987; Toggweiler et al., 1989). Even when biology was acknowledged as the primary mechanism controlling atmospheric $\mathrm{pCO}_{2}$, it was modeled as a strictly geochemical or stoichiometric process (e.g. Sarmiento et al., 1988).

One reason for underestimating the role of marine biota has been the scale, both temporal (annual) and spatial $(\mathrm{km})$, used in most physical models. Biological processes are often patchy and cyclic or episodic, particularly in the Arctic. If export is sensitive to the scale over which it is averaged (extremely probable in the temporally and spatially heterogeneous Arctic), it can thus be incorrectly estimated by large scaling. Since we began our investigation, an entire NATO ASI workshop was devoted to developing an oceanic carbon cycle model with improved biogeochemistry. The problem of scale was identified as a key issue (Evans and Fasham, 1993) with the recommendation that "detailed high resolution models rich in vertical structure and biological detail" be developed (Murphy et al., 1993).

A related problem in the existing geochemical models was incomplete parameterization of nutrient recycling. Historically, modelers had only considered new production important to determining carbon flux from the euphotic zone. By definition (Eppley and Peterson, 1979), this parameterization assumes a system at steady state. Having studied the deepsea benthos, I was aware that export from the euphotic zone could be highly episodic (Theil et al., 1988), and that assumptions of steady state were often 
invalid or highly sensitive to the chosen time scale. Also, remineralization of $\mathrm{CO}_{2}$ was traditionally linked to the nitrogen or phosphate cycle using Redfield ratios. No allowances were made for decoupling of these processes. Organismal carbon-to-nitrogen ratios are often out of balance with the Redfield ratio (see for example Chapter 2 of Parsons et al., 1984), but only recently has it been recognized that entire oceanic regions may not always follow Redfield ratios either (Sambrotto et al., 1993).

Awareness of these issues was not lacking for at least some of the modelers, who acknowledged that the potential impact of including biological processes in modeling the oceanic uptake of atmospheric $\mathrm{pCO}_{2}$ was of the same order of magnitude as the anthropogenic source itself (Sarmiento et al., 1989). The problem was building a biological model simple enough to incorporate into a computationally-large global general circulation model (GCM). Somehow simplicity had to be accomplished with the integrity of the biological system still intact. To somewhat ease this dilemma, the NATO workshop recommended building models designed to address specific questions (Murphy et al., 1993). When asking questions about the linkage between marine biota and climate change, they recommended that future models focus on those biotic components likely to be sensitive to variations in temperature, for example.

At the time (and still to some extent today), modeling in biological oceanography was focused on understanding the controls on primary production rather than how biological processes influence biogeochemical cycling. In our examination of existing models of biological processes we typically found either no linkage to the inorganic carbon cycle (Evans and Parslow, 1985; Frost, 1987; Fasham et al., 1990) or, if there was linkage, poor 
representation of any reasonably complex marine ecosystem (e.g., Taylor et al., 1991, and more recently, Antoine and Morel, 1995a, 1995b, although both models found biological influence on oceanic $\mathrm{PCO}_{2}$ despite their simplified biological parameterizations). The Fasham et al. (1990) model was probably the best of the genre in that it captured most of the basic biological components, but structural sensitivity and the role of complexity remained untested, nor was it linked to the atmosphere. Ultimately, their model would be incorporated into the Princeton GCM (Fasham et al., 1993; Sarmiento et al., 1993) for sensitivity analyses and comparison to satellite (surface chlorophyll) observations (Slater et al., 1993). The effects of complex marine food webs, particularly the role of the microbial loop, on air-sea flux of $\mathrm{CO}_{2}$ remain unexamined, however, as do perturbation studies addressing anthropogenic $\mathrm{CO}_{2}$.

We constructed from existing models a unique hybrid that linked a complex marine food web, such as those developed by Fasham et al. (1990), to an oceanic inorganic carbon cycle and a local atmosphere, letting the $\mathrm{CO}_{2}$ flux vary as a function of the short term gradients developed between the surface ocean and the atmosphere. Our specific goal was to test the sensitivity of airsea carbon flux and the uptake of the anthropogenic transient to biological processes using a more sophisticated biological model than used previously, but with a simple ocean and atmosphere. To this day, testing for biological sensitivity in oceanic uptake of the anthropogenic $\mathrm{CO}_{2}$ transient remains a unique aspect of our modeling approach.

Our hypothesis was that the storage of carbon in organic biomass, even if only during certain times of the year, could have an effect on the annual uptake capacity of the ocean. In addition to the traditional expectation that 
export of carbon from the surface to deep ocean occurs via the vertical flux of particulate and dissolved organic carbon, we hypothesized that export might also occur in the form of dissolved inorganic carbon if the ocean was not in steady state and the inorganic carbon and nitrogen remineralization cycles were decoupled. This process seemed possible due to the fact that most of the $\mathrm{CO}_{2}$ in the ocean is not in the form of $\mathrm{pCO}_{2}$ (e.g., the Revelle buffer factor; Broecker and Peng, 1982), yet the air-sea flux is driven by the $\mathrm{pCO}_{2}$ gradient alone. For every ppm of $\mathrm{pCO}_{2}$ that moves from the atmosphere to the $\mathrm{pCO}_{2}$ of the ocean because of a gradient, $\sim 10 x$ that amount also gets shunted into the rest of the oceanic carbonate system before the gradient is reduced.

We emphasized at the time that the model we constructed was a preliminary attempt to test our hypothesis. The biological processes we included in our model were still poor representations of a complex biological system (resembling the Fasham et al., 1990 model) and the simple ocean model was missing some key ingredients (e.g. advection or loss terms). We also never incorporated unique Arctic characteristics, (e.g., boreal light, low temperature, or ice cover) since we started with parameterizations published for Weather Station "Papa" in the sub-arctic Pacific (Frost, 1987). After describing the preliminary model and what we were able to determine from it, I will conclude this chapter with funded plans to refine the model as a. postdoctoral fellow. Despite the fact that the project remains unfinished, and advances to the field have been made during the interim, the exercise of initiating it had great impact on my thinking. Ideas that originated during the building and testing of this model are woven throughout my graduate research efforts and the scientific approach I take with me into the future. As such, the preliminary model has earned a place in my dissertation. 


\section{Model Description}

\section{Physical dynamics}

We developed a one-dimensional box diffusion model for the ocean with high vertical resolution $(5 \mathrm{~m})$ in the upper $100 \mathrm{~m}$. This resolution gradually decreases towards the deepest box at $1000 \mathrm{~m}$ depth (Fig. I-1).

Ocean dynamics are defined by turbulent mixing with a diffusion coefficient of $K=1 \times 10^{-6} \mathrm{~m}^{2} \mathrm{~s}^{-1}$ for the deep ocean (in retrospect, this value is too low and likely resulted in a sluggish deep ocean). A seasonally sinusoidal mixed-layer depth (ranging from $25 \mathrm{~m}$ in the summer to $125 \mathrm{~m}$ in the winter) is included (Fig. I-2). Within the mixed layer, we increase the turbulent mixing by two orders of magnitude to a diffusion coefficient of $\mathrm{K}=1.0 \times 10^{-4}$ $\mathrm{m}^{2} \mathrm{~s}^{-1}$. Deepening of the mixed layer entrains water properties from beneath.

We solved the diffusion equation using an implicit finite-difference numerical method. For all grid points, the concentration at the new time step is calculated simultaneously. Since implicit methods are unconditionally stable, it allows us to specify a time step of one day.

To investigate the atmospheric response, we added an atmosphere (single box; Fig. I-1) which connects to the ocean surface by a simple flux equation. The only property transferred across the air-sea interface is carbon dioxide concentration. We determined the flux of $\mathrm{CO}_{2}$ by a constant gas exchange coefficient, $\lambda=0.05 \mathrm{~mol} \mathrm{l}^{-1} \mathrm{yr}^{-1} \mathrm{ppm}^{-1}$ (Broecker and Peng, 1974).

In the surface ocean, we calculated the full carbon chemistry (e.g., the formation of bicarbonate and carbonate dependent on alkalinity and temperature; Broecker and Peng, 1982). Solubility of carbon dioxide changes 


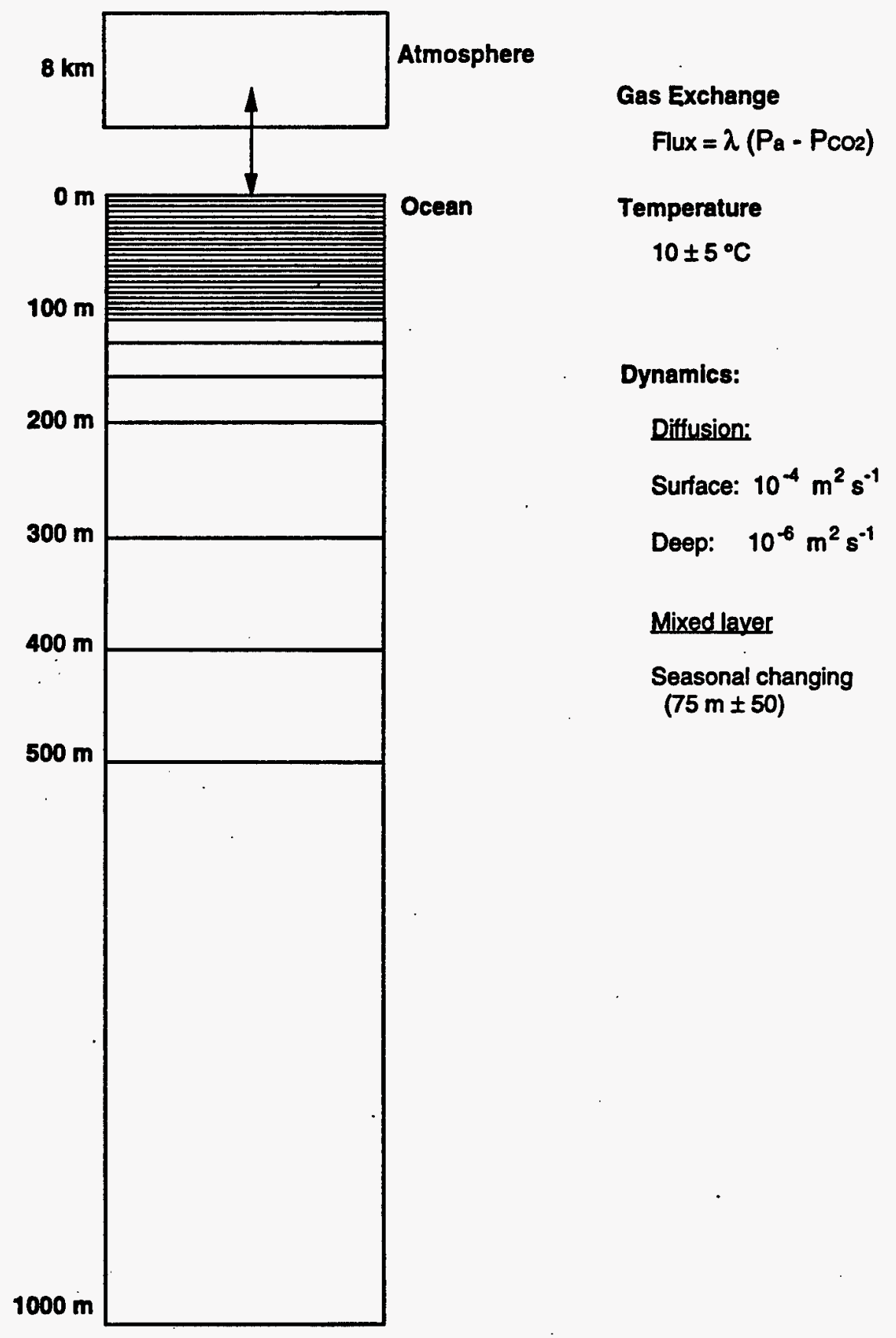

Figure I-1. The dynamical model. Twenty-eight oceanic boxes decreasing in resolution with depth. Box number starts with 1 at the surface and increases to 28 on the bottom. 


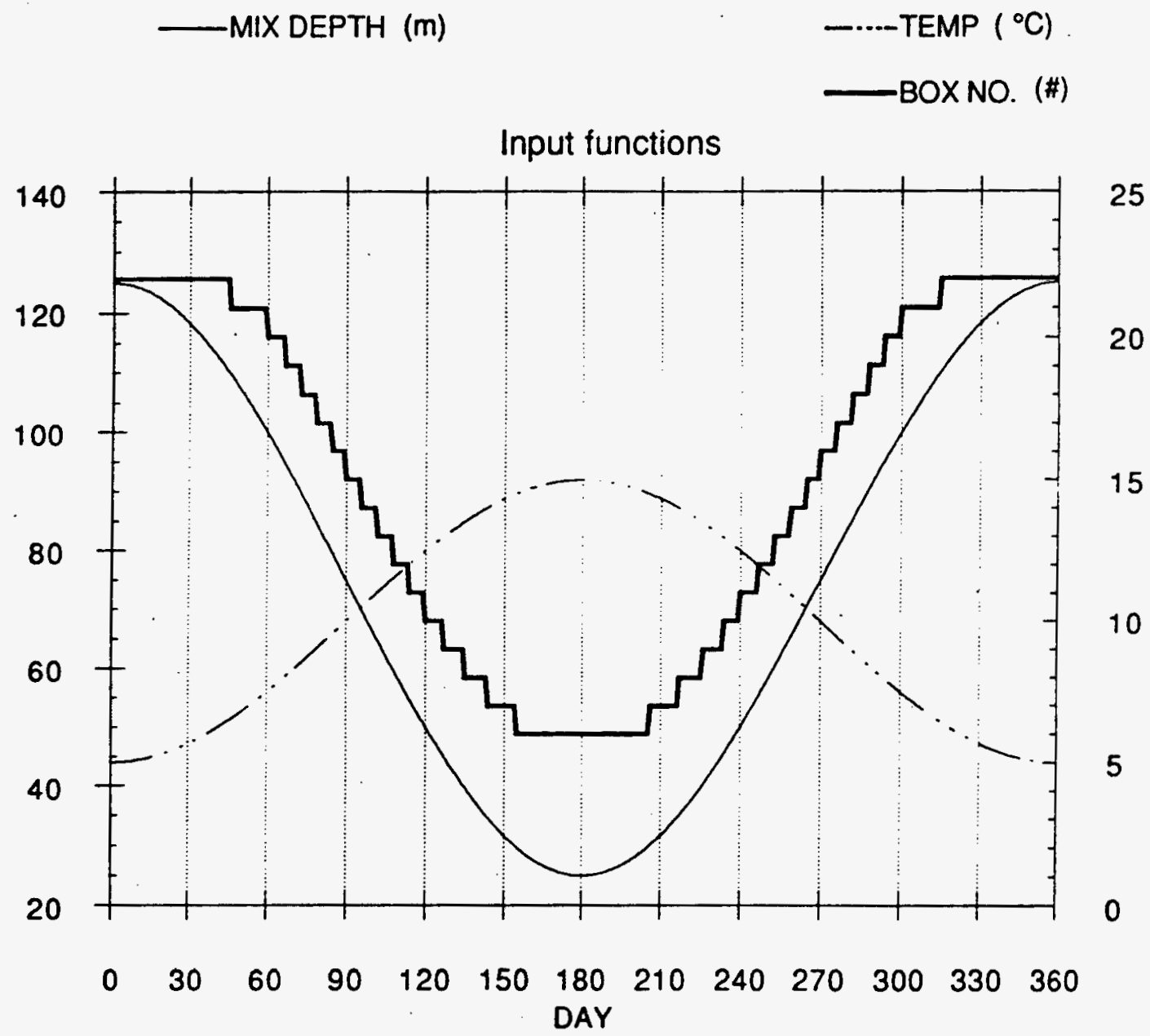

Figure I-2. Input functions of the dynamical model as a function of time (Day 1 = January $1 ; 1 \mathrm{y}=360 \mathrm{~d})$. Mixed-layer depth ( $\mathrm{m}$; thin solid line) varies sinusoidally between a maximum of $125 \mathrm{~m}$ and a minimum of $25 \mathrm{~m}$. Box number (thick solid line) refers to the box which contains the base of the mixed-layer. Temperature $\left({ }^{\circ} \mathrm{C}\right.$; dashed line) is also forced by a sinusoidal function which ranges from 5 to $15^{\circ} \mathrm{C}$. 
with temperature. Seasonal variations of temperature are prescribed as a sinusoidal function within the range from $5^{\circ}$ to $15^{\circ} \mathrm{C}$ (Fig. I-2).

\section{Biology}

Our biological model is a simplified version of the pelagic microbial loop (sensu Deming and Baross, 1993; Jumars et al., 1989; originally inspired by classic papers of Pomeroy, 1974, and Azam et al., 1983). We chose three major groups of organisms (phytoplankton, zooplankton, and bacteria) as simplified representatives of three different trophic levels. A single "chimeric" zooplankton group consumed both phytoplankton and bacteria. To model the biological cycle, organisms as well as other organic and inorganic species were considered as concentrations of carbon or nitrogen per unit volume of seawater (Fig. I-3). Exchanges between them were described by fluxes of carbon or nitrogen per time step (Fig. I-3; arrows). Interactions between pools were either modeled as Michaelis-Menten kinetic processes (e.g. uptake of dissolved nutrients and grazing rates) or prescribed as fractions of present concentration (e.g., excretion, respiration, and death). Uptake rates and half-saturation constants were chosen or estimated from published values (Table I-1). The carbon to nitrogen ratio used for all pools of organic matter was 106:17 (Redfield et al., 1963).

Phytoplankton production rates were based on the temperature and light forcing scheme of Frost (1987; mimicking temperature and light levels at $50^{\circ} \mathrm{N}$; Fig I-4). Phytoplankton could take up either ammonium $\left(\mathrm{NH}_{4}\right)$ or nitrate $\left(\mathrm{NO}_{3}\right)$. To model their overall preference for $\mathrm{NH}_{4}$ (Goldman and Glibert, 1983), we used an exponential damping function such that high $\mathrm{NH}_{4}$ concentrations inhibited $\mathrm{NO}_{3}$ utilization. Zooplankton grazed on both 


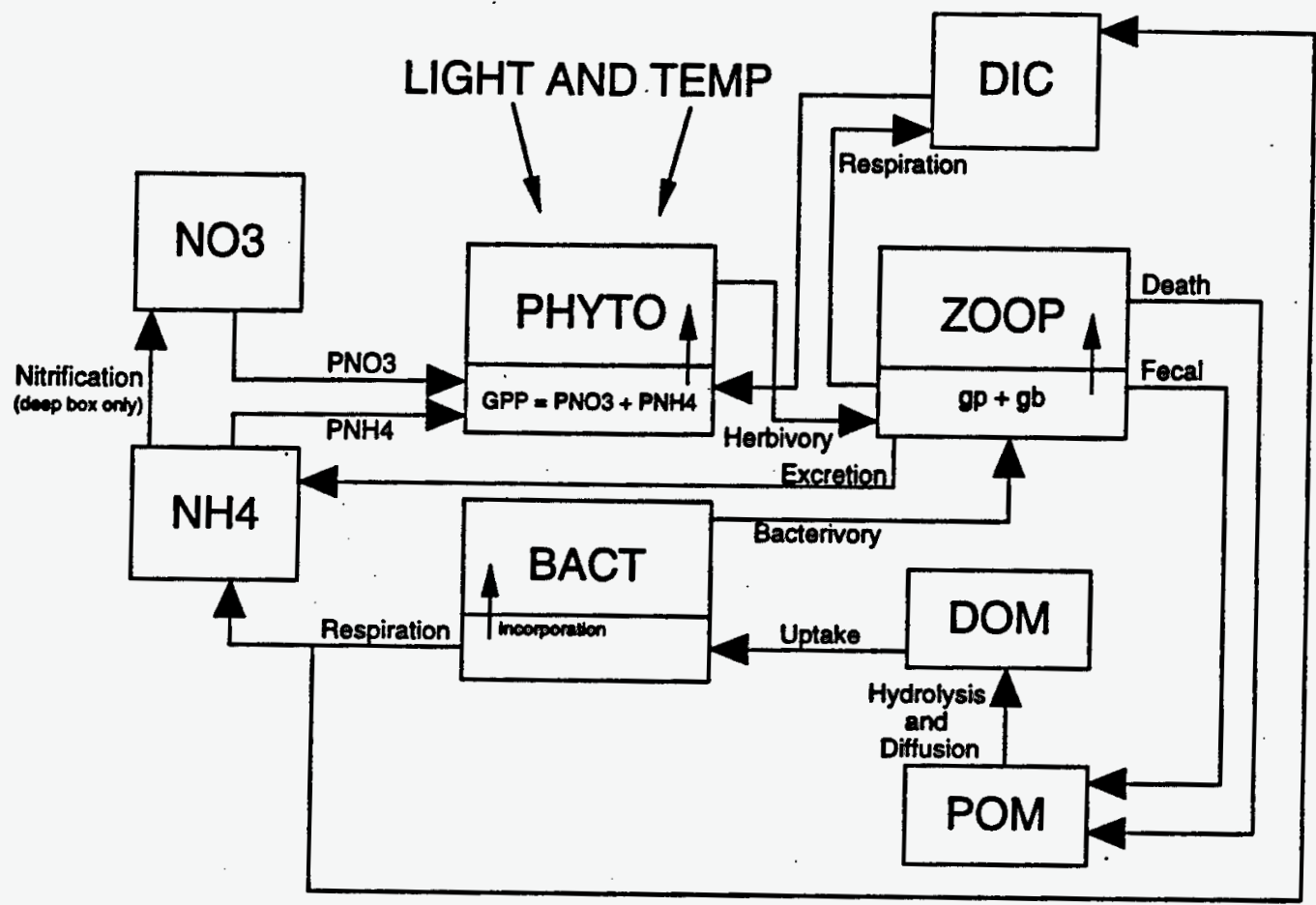

Figure I-3. The biological model where boxes indicate biomass or concentration in terms of $\mathrm{C}$ and/or $\mathrm{N}$ per unit volume seawater and arrows indicate fluxes of $C$ and/or $N$ per unit volume per unit time. PHYTO indicates phytoplankton; ZOOP, zooplankton; BACT, bacteria; DIC, dissolved inorganic carbon; DOM, dissolved organic matter; POM, particulate organic matter; NH4, ammonium; NO3, nitrate; $\mathrm{PNH4}$, primary production using ammonium; PNO3, primary production using nitrate; GPP, gross primary production; gP, grazing of phytoplankton; gb, grazing of bacteria. 
phytoplankton and bacteria only to prescribed refuge concentrations (Eccleston-Parry and Leadbeater, 1994; Heinbokel, 1978). Zooplankton contributed to the dissolved organic matter (DOM) pool via incomplete digestion that depended on fecal pellet production (Jumars et al., 1989). Bacteria took up DOM only, but there was a hydrolysis function that allowed bacteria to turn particulate organic matter (POM) into DOM directly via extracellular enzymatic activity (Hoppe et al., 1988; Hoppe et al., 1993). Heterotrophic activities by both zooplankton and bacteria remineralized organic biomass to dissolved inorganic carbon (DIC) and ammonium.

Nitrate was recycled in the deepest box. All ammonium which was mixed to this layer was transformed into nitrate. Nitrate returned to the surface layers by mixing. All concentrations of organic and inorganic species were transported by the oceanic dynamics described above. Only POM was advected vertically, determined by its sinking rate.

Four sensitivity experiments tested the model response to changes in maximum grazing rates, bacterial incorporation efficiency (fraction of consumed carbon going to biomass), phytoplankton aggregation and sinking, and zooplankton excretion and respiration fraction (Table I-1).

\section{RESULTS AND DISCUSSION}

\section{Standard model time-series}

Our standard model ran to equilibrium for $300 \mathrm{y}$. We examined equilibrium results by integrating biological concentrations over the top $50 \mathrm{~m}$ (our euphotic zone). Observations of these values for the first $10 \mathrm{y}$ after the 300-year run indicated that the model had reached steady state (data not 
Table I-1: Parameters used in model and their assigned values.

\begin{tabular}{ccccc} 
Parameter: & $\begin{array}{c}\text { Symbol Standard } \\
\text { Value }\end{array}$ & Units & $\begin{array}{c}\text { Expt. } \\
\#\end{array}$ & $\begin{array}{c}\text { New } \\
\text { value }\end{array}$ \\
\hline
\end{tabular}

Light: $^{a}$

Light as function of time Io $225 \pm 150 \quad \mathrm{lyd}^{-1}$

Light at surface alight 30 to 140

Attenuation attu

0.1 $m^{-1}$

Phytoplankton:

Half-saturation for

hkn $\quad 1 \times 10^{-6} \quad \operatorname{molN~}^{-1}$ nutrient uptake $b$

$\mathrm{NH} 4$ damp of $\mathrm{NO} 3$ amdamp $\left.1 \times 106 \quad(\operatorname{molN~})^{-1}\right)^{-1}$ uptake $b$

Chlorophyll-specific PMAX 20 to 80 mgCmgChl $a^{-1}$ maximum growth rate ${ }^{a}$

Carbon: chlorophyll ratio $a$ c $\quad 30 \quad \mathrm{mgCmgChl} a^{-1}$

Minimum concentration

Threshold concentration Pmin $0.1 \times 10-6$ $\mathrm{molCl}^{-1}$ pocmax - $\operatorname{molCl}^{-1} \quad 35 \times 10^{-6}$ for aggregation (Expt. 3 only)

\section{Grazers:}

Half-saturation for hkgp $\quad 0.1 \times 10^{-6} \quad \mathrm{molCl}^{-1}$ herbivory

Mass-specific maximum grazp 1 $d^{1}$ 110 herbivory

Threshold concentration Pmin $0.1 \times 10^{-6} \mathrm{molCl}^{-1}$ for herbivory 
Table I-1 (continued)

Half-saturation for

hkgb

$0.1 \times 10^{-6} \quad \mathrm{molCl}^{-1}$

bacterivory $b$

Mass-specific maximum

grazb

1

$\mathrm{d}^{-1}$

1

10

bacterivory $b$

Threshold concentration $\mathrm{Bmin} \quad 0.1 \times 10^{-6} \mathrm{molCl}^{-1}$

for bacterivoryb

Excretion and respiration excret 0.40

(fraction of intake)

Fecal pellet fraction

fecal $\quad 0.30$

$4 \quad 0.20$

(fraction of intake)

Death of grazers (fraction death 0.30

of total biomass)

Bacteria:

Half-saturation for DOM hkb $5 \times 10^{-6} \quad \mathrm{molCl}^{-1}$ uptake by bacteriab

Maximum bacterial uptake rate $b$

Bacterial respiration

bacres $\quad 0.80$

$2 \quad \mathrm{~d}^{-1}$

efficiency

POM and DOM:

Hydrolysis/diffusion half- hkhy $0.5 \times 10^{-6} \mathrm{molCl}^{-1}$ saturation coefficient

Sinking distance per day sinkrate $50 \quad \mathrm{~m}$

Carbon: Nitrogen ratio $c$ rnc $\quad 106: 17 \quad \mathrm{molCmolN}^{-1}$

${ }^{a}$ from Frost (1987)

${ }^{b}$ from Sarmiento et. al., (1989)

${ }^{c}$ from Redfield et al. , (1963) 
Figure I-4. Light forcing functions: a) fraction of surface light decreasing with depth (m) creates a euphotic zone of about $50 \mathrm{~m}$; and b) light and temperature effects on phytoplankton production (from Frost, 1987), where PMAX* (dashed line) indicates maximum uptake of phytoplankton (mg C per mg chlorophyll a per day) as a function of carbon to chlorophyll ratio, temperature, and daylength as defined by Frost (1987); ALIGHT (thin solid line), $\alpha$ PARz/e-(attenuation $x$ depth) where $\alpha$ PARz is defined by Frost (1987) as the photosynthetically available radiation used by phytoplankton; and VMAX/CARCHL (thick solid line), (PMAX $\left.{ }^{*}\right)\left(\tanh \left(\alpha \mathrm{PARz} / \mathrm{PMAX}^{*}\right) / \mathrm{c}\right.$, where $\mathrm{c}$ is the carbon to chlorophyll ratio. 

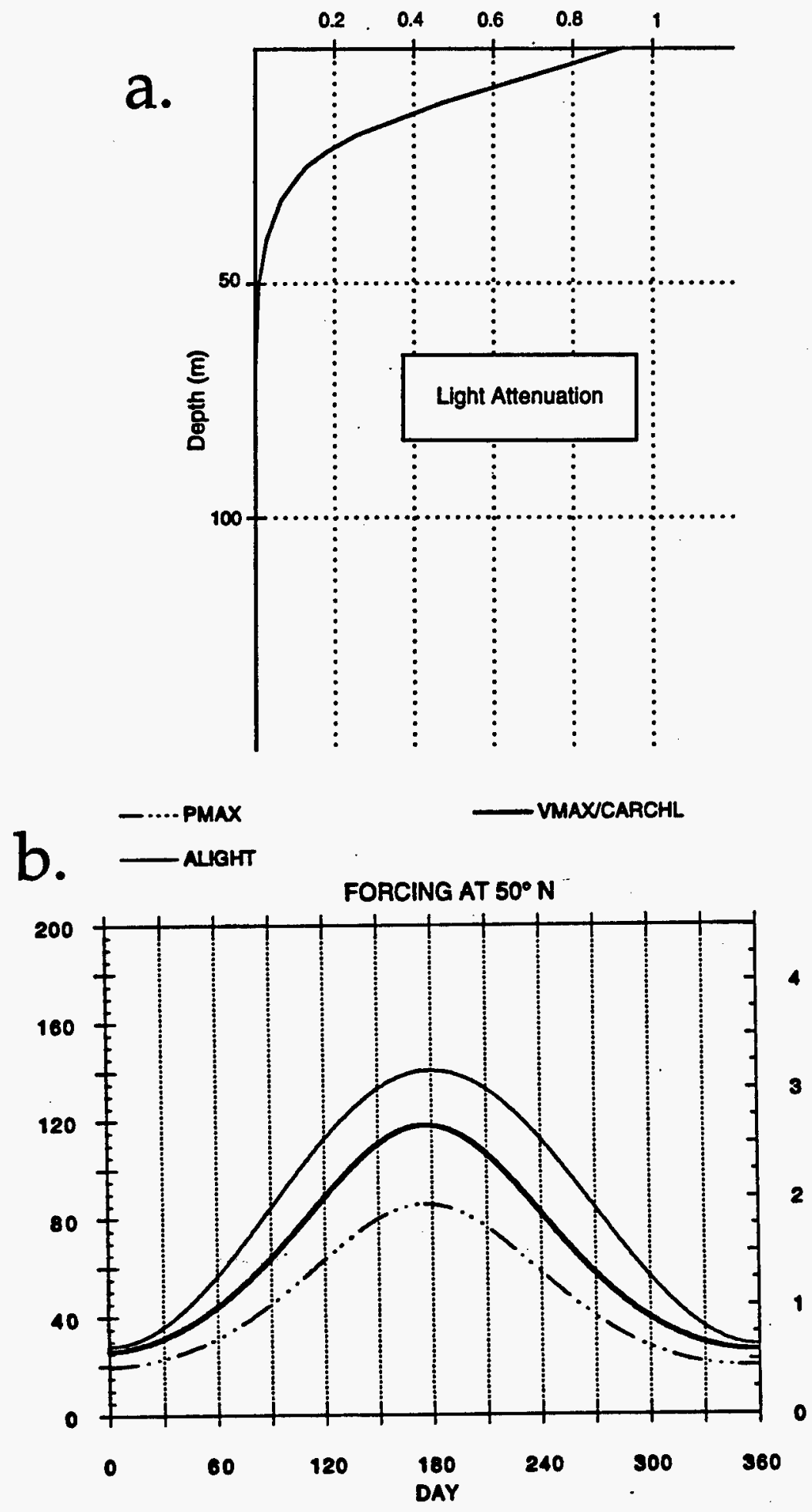
shown). Annual cycling of primary production was strongly determined by mixed-layer depth and nutrients. However, since light could penetrate belowthe shallow summer mixed-layer, some production occurred there as well. A seasonal cycle was set up by light and temperature forcing on the phytoplankton (Fig. I-5a). As light increased in the early spring ( Day 60 ), when bacterial biomass and nutrients were relatively high, phytoplankton production increased. Production with ammonium was much higher than that with nitrate. Springtime f-ratios (nitrate production to total production) reached the typical open-ocean level of $\sim 0.06$ (Eppley and Peterson, 1979). Phytoplankton biomass increased significantly enough by late Spring (Fig I-5b; $\sim$ Day 160) to result in greater grazing rates and thus higher zooplankton biomass (Day 200). With greater zooplankton uptake, $\mathrm{NH}_{4}$ excretion and $\mathrm{CO}_{2}$ respiration increased, along with fecal pellet production and zooplankton death. This contributed to the DOM pool via POM such that bacterial uptake increased and bacterial biomass accumulated in the Fall (Fig. I-5c; Day 270). This secondary increase of bacteria also stimulated a small secondary increase in zooplankton biomass. Increasing bacterial remineralization, coinciding with the deepening of the mixed-layer, contributed to the winter build-up of nutrients and the resulting spring bloom.

\section{Standard model depth profiles}

During springtime, nutrients were low in the surface layers $(0-150 \mathrm{~m})$, while production was limited to the upper $50 \mathrm{~m}$ (Fig. I-6a). High production rates caused low levels of nutrients. Nutrients increased with depth due to sinking POM, high bacterial biomass (Fig. I-6b), and resulting remineralization. 


\section{Sensitivity experiments}

Our first sensitivity experiment tested the effect of increasing the maximum grazing rate by a factor of ten (Table I- 1 ; grazb and grazp $=10$ ). The resultant increase in zooplankton grazing and excretion dramatically increased ammonium concentration at the surface. Production with ammonium was low, however, because phytoplankton biomass was constantly grazed to its refuge level (Fig. I-7a). High ammonium concentration inhibited nitrate utilization, resulting in a relatively high surface concentration of nitrate, but an extremely low f-ratio (Fig. I-7a). Zooplankton biomass doubled (Fig. I-7b) and cycled in phase with primary production; a lag no longer existed between them. Bacterial biomass was also kept to the refuge level by grazers.

The second sensitivity experiment decreased the respired fraction of bacterial uptake by a factor of four, with more of the utilized carbon and nitrogen incorporated into bacterial biomass. This resulted in greater bacterial biomass in most of the water column and lower ammonium concentrations in the surface waters. Consequently, primary production with ammonium was lower such that the f-ratio increased (Fig. I-8).

For the third sensitivity experiment, we set a threshold level of phytoplankton biomass ("pocmax"), above which cells aggregated and sank out of the surface as POM and the surface concentration of phytoplankton dropped to its refuge concentration $\left(P_{\min }\right)$. We anticipated that this process would result in a loss of carbon and nutrients from the surface, but because of the efficiency of the microbial loop and the degree of vertical mixing, the model achieved faster and more complete recycling through bypassing the 
Figure I-5. Standard model results as a function of time, where Day $1=$ January 1, $300 \mathrm{y}$ after initial conditions, and $1 \mathrm{y}=360 \mathrm{~d}$; a) phytoplankton production ( $\mathrm{mg} \mathrm{C} \mathrm{m}^{-2}$ ) integrated over the euphotic zone (upper $50 \mathrm{~m}$ ) using nitrate (PNO3, thin dashed line) and ammonium (PNO4, solid line), where the F-ratio (heavy dashed line) is $\mathrm{PNO} /(\mathrm{PNO}+\mathrm{PNH} 4) ; \mathrm{b}$ ) phytoplankton (dashed line) and zooplankton (solid line) biomass averaged over upper $50 \mathrm{~m}$ $\left(\mu \mathrm{mol} \mathrm{C}^{-1}\right)$; c) bacterial biomass (dashed line) averaged over upper $50 \mathrm{~m}$ $\left(\mu \mathrm{mol} \mathrm{C1^{-1 }}\right)$. 


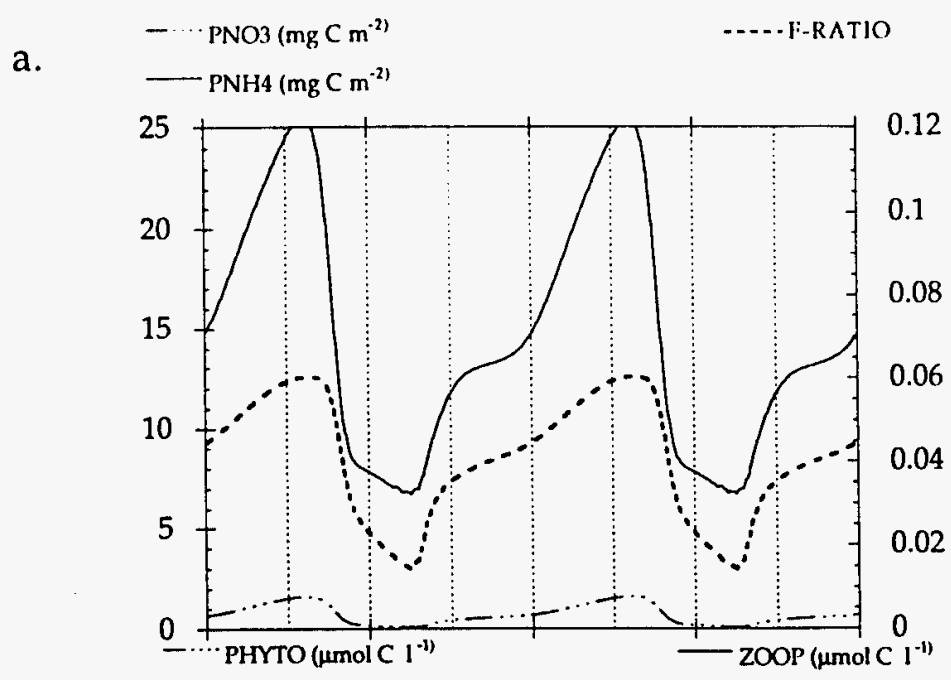

b.

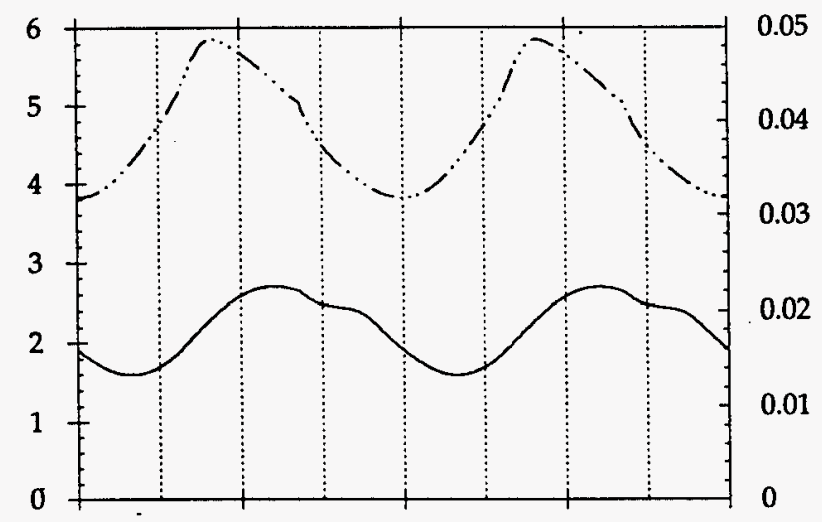

c.

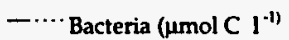

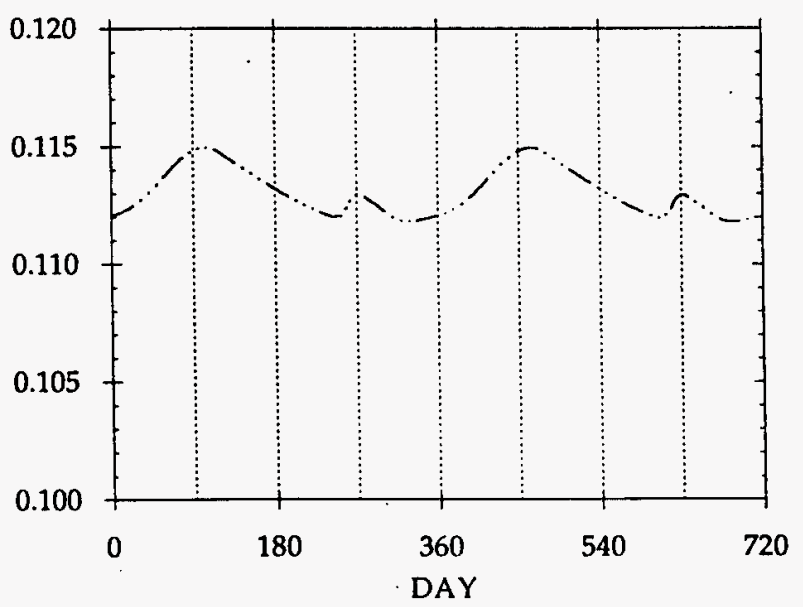


Figure I-6. Standard model results as a function of depth $(\mathrm{m})$ for Spring (Day 90) of year 300 for: a) nutrients and production, where NO3 (thin solid line) and NH4 (thin dashed line) are expressed in mol $\mathrm{N}^{-1}$, and phytoplankton production using nitrate (PNO3, thick dashed line) and ammonium (PNH4, thick solid line) are expressed in mol $\mathrm{C} \mathrm{l}^{-1}$; and b) phytoplankton (thick dashed line), zooplankton (solid line), and bacterial biomass (thin dashed line) expressed in $\mathrm{mol} \mathrm{Cl}^{-1}$. 
a.

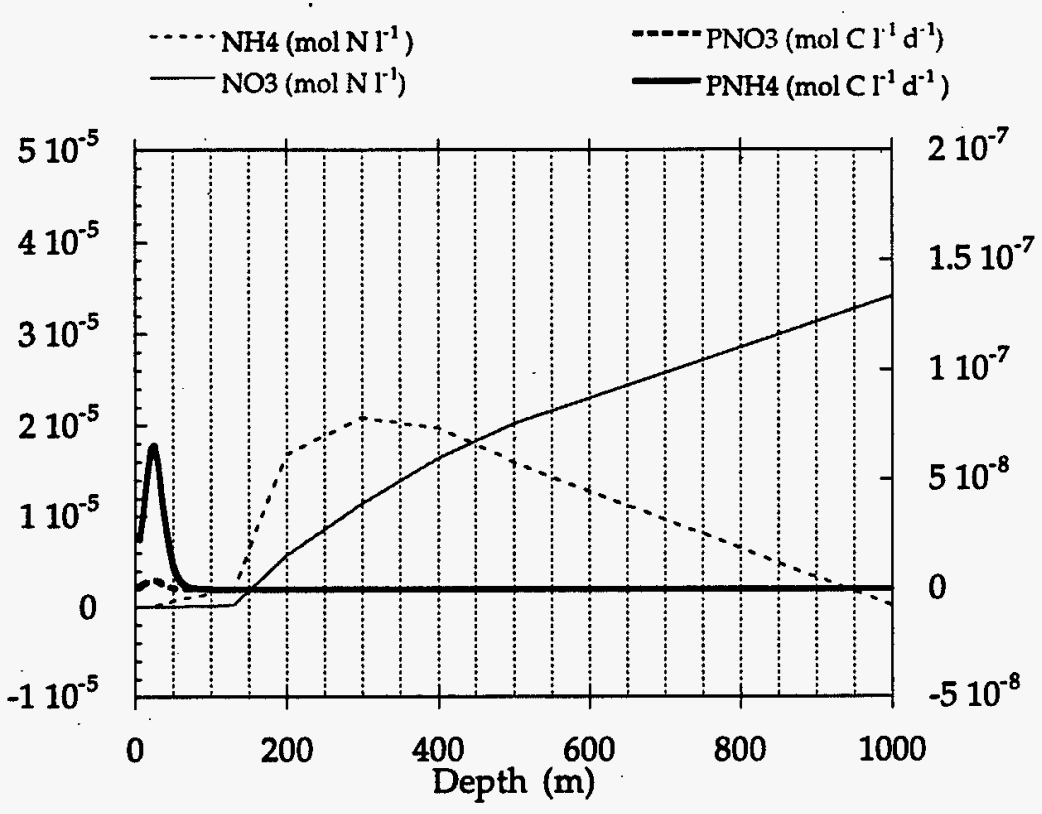

b.

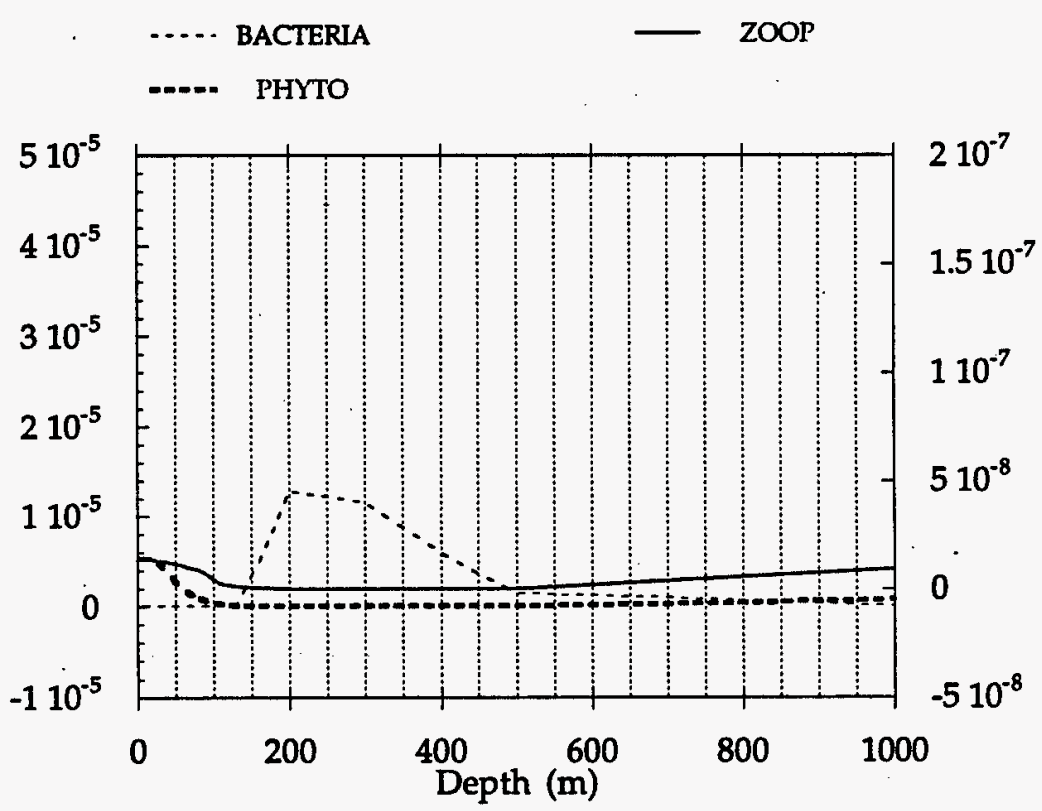


Figure I-7. Model results from increased grazing rate (Experiment \#1): a) phytoplankton production integrated over the euphotic zone (upper $50 \mathrm{~m}$ ) using nitrate (PNO3; dotted line) and ammonium (PNH4; solid line, uppermost curve) in $\mathrm{mg} \mathrm{C} \mathrm{m}{ }^{-2}$, where F-ratio (dashed line, lowermost curve) is $\mathrm{PNO} 3 /(\mathrm{PNO}+\mathrm{PNH} 4)$; b) phytoplankton (dotted line), zooplankton (solid line; uppermost curve) and bacterial biomass (dashed line, overlaps somewhat with PHYTO) averaged over upper $50 \mathrm{~m}\left(\mu \mathrm{mol} \mathrm{C}{ }^{-1}\right)$. 


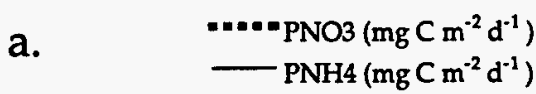

- - F-RATIO

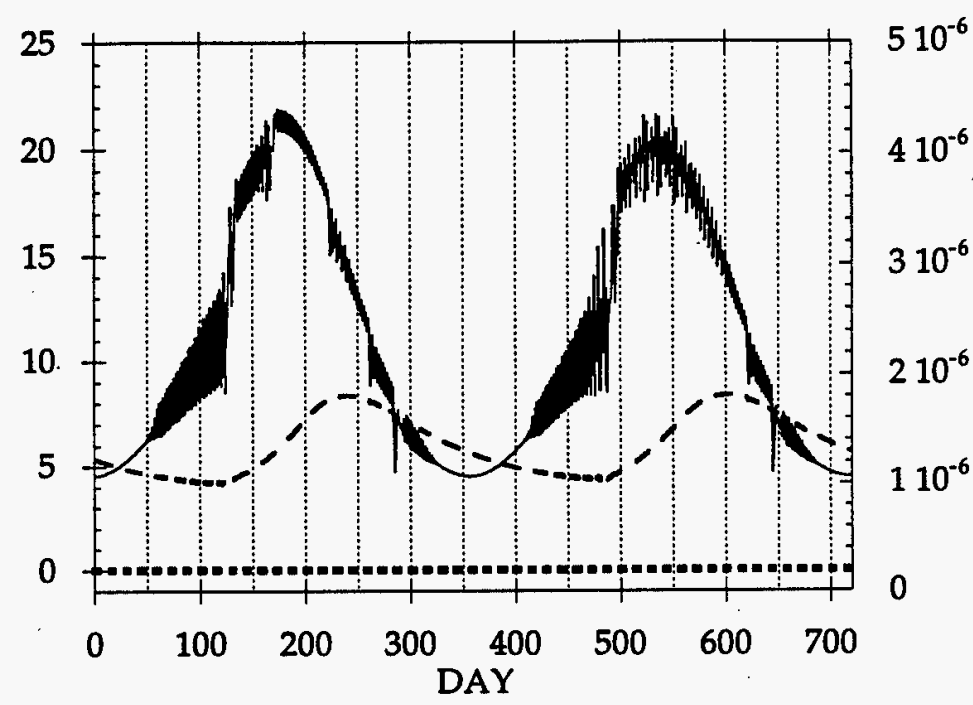

b. $\quad \cdots \cdots$ PHYTO $\left(\mu \mathrm{mol} \mathrm{Cl}{ }^{-1}\right)$ ZOOP $\left(\mu \mathrm{mol} \mathrm{Cl} \mathrm{l}^{-1}\right)$ - BACTERIA ( $\left.\mu \mathrm{mol} \mathrm{C}^{-1}\right)$

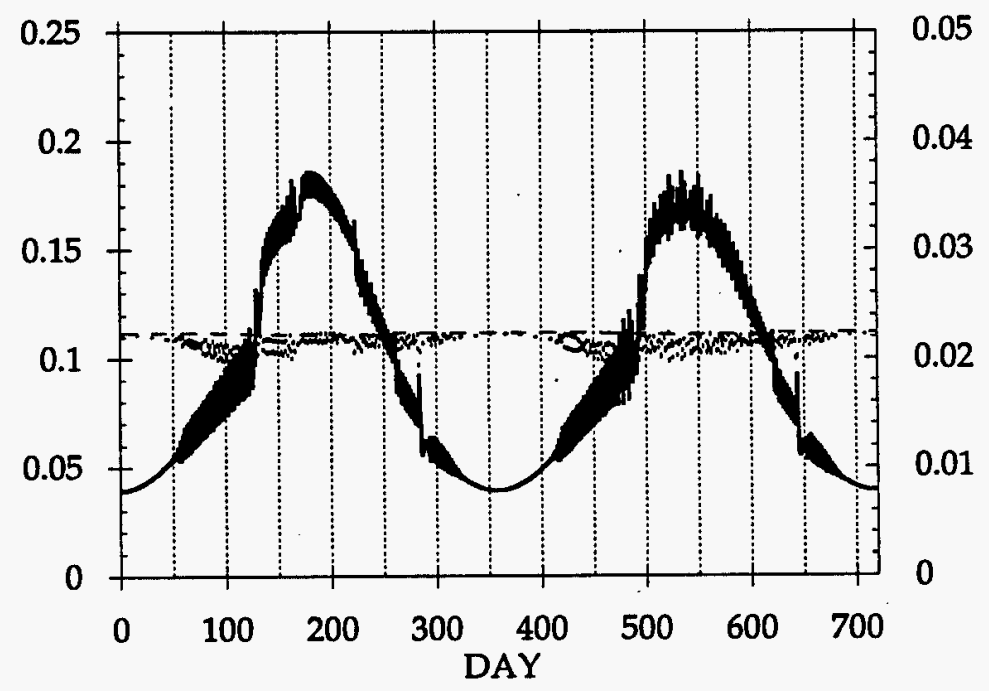


Figure I-8. Model results from increased bacterial efficiency (Experiment \#2): phytoplankton production integrated over the euphotic zone (upper $50 \mathrm{~m}$ ) using nitrate (PNO3; thin dotted line) and ammonium (PNH4, solid line) in $\mathrm{mg} \mathrm{C} \mathrm{m}{ }^{-2}$, where F-ratio (heavy dashed line) is $\mathrm{PNO} /(\mathrm{PNO} 3+\mathrm{PNH} 4)$. 

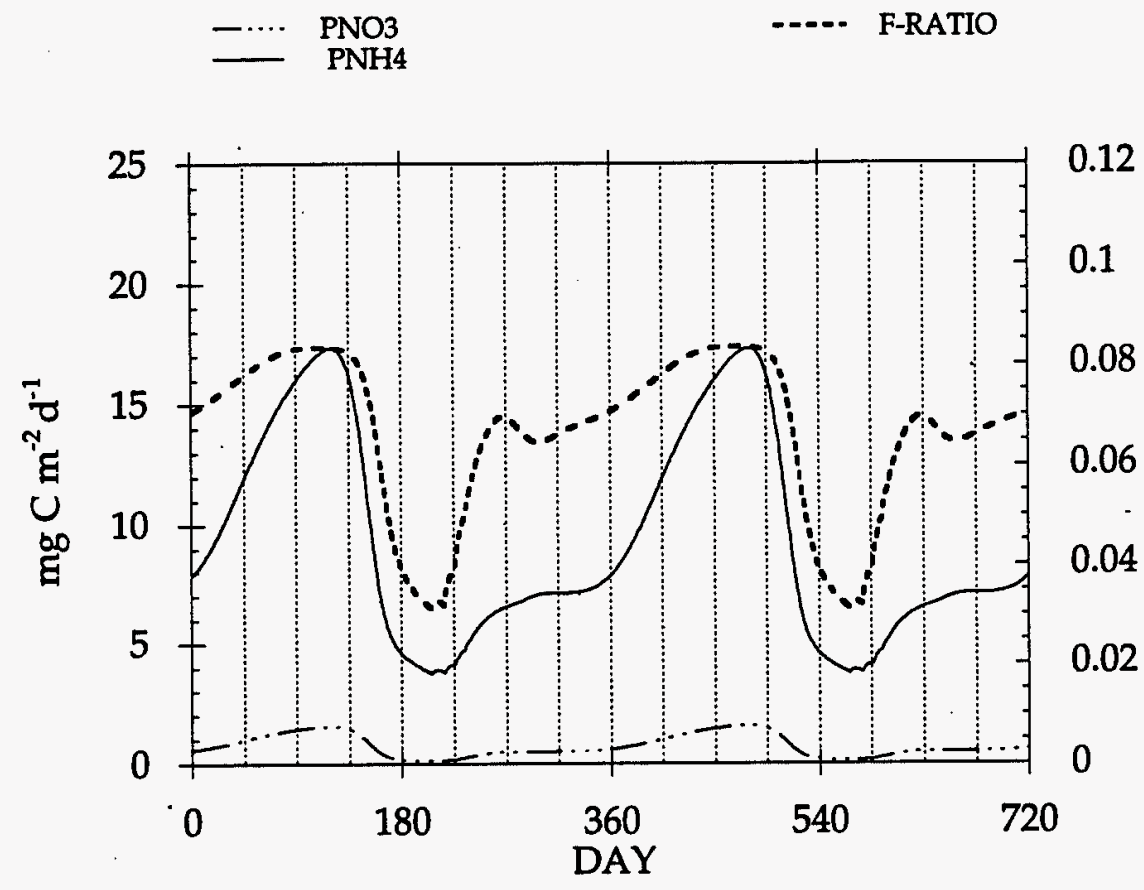
grazer step. This interesting result is sensitive to the extent of hydrolysis of POM by bacteria, but may be important in some parts of the ocean. As in the standard model, phytoplankton production and biomass increased in the Spring (Fig I-9 $\mathrm{a}$ and $\mathrm{b}$ ). Once the threshold concentration was reached ( Day 100), however, all of the "excess" biomass (phytoplankton concentration $P_{\min }$ ) is shunted into POM and sinks. (Note: phytoplankton concentration never dropped to $P_{\min }$ on our time-series plots because we averaged the entire $50 \mathrm{~m}$ water column.) The high production of POM which resulted from phytoplankton sinking contributed to a higher DOM pool (via hydrolysis) and more bacterial biomass (Fig. I-9c; Day 100). Increased remineralization rates also increased nutrient concentrations and phytoplankton production (Fig I9a). As a result, even zooplankton biomass increased (Fig I-9b). This outcome was almost certainly sensitive to the sinking rate of POM, the depth of the model ocean, and vertical mixing rates.

The fourth sensitivity experiment decreased the fraction of grazer uptake lost to respiration, excretion, and fecal pellets by a factor of two. As with the bacteria in Experiment \#2, this increased zooplankton incorporation efficiency and biomass. Our model was highly sensitive to this parameter. Variations with time become much stronger (Fig. I-10a) and zooplankton biomass can, for a short time, be two orders of magnitude higher than in the standard model (Fig. I-10b). This strong episodicity occurs because nutrients are not limiting phytoplankton growth and, thus, both phytoplankton and zooplankton operate at or near their maximum growth rates. Since phytoplankton have doubling times faster than zooplankton, they pace ahead of the grazers just enough to allow exponential growth. With the increase in food concentration, however, the zooplankton soon caught up to and 
ultimately decimated the phytoplankton population. Such a high zooplankton biomass contributed significantly to nutrient pools, even with high incorporation efficiency. All of this adds to the nutrient pool and stimulates a second phytoplankton bloom (Fig. I-10a and b; Day 150).

Interestingly, some instabilities also existed in this version of the model, even though it ran at equilibrium for over $300 \mathrm{y}$; slight differences occurred in the seasonal patterns of biomass and production from one year to the next (compare the two summer production or f-ratio curves at $\sim$ Day 190 and $\sim$ Day 550; Fig. I-10a).

With this strong result, we compared the standard seasonal sea-to-air carbon flux calculated by the standard model (where $\mathrm{CO}_{2}$ fluxes between the surface ocean and the atmosphere mostly as a function of temperature) to that which resulted from the high-efficiency grazer run. As we hypothesized, episodic biological processes lead to episodic reduction of the summertime efflux of $\mathrm{CO}_{2}$ from the ocean to the atmosphere (Fig. I-11). This sensitivity to a single parameter may be the first indication of how potential nonlinearitiesin the biological system can impact physical and chemical processes in the ocean.

\section{Perturbation experiment}

To see if perturbations in the seasonal uptake of $\mathrm{CO}_{2}$ could affect the longer-term net uptake of a transient increase in $\mathrm{CO}_{2}$ we ran both the standard model and the high-efficiency grazer model to equilibrium, then added a one-percent-per-year increase in atmospheric $\mathrm{pCO}_{2}$. The resulting profiles of the transient $\mathrm{CO}_{2}$ taken up in the two models show little difference after $100 \mathrm{y}$ (Fig. I-12). If anything, the standard model shows a slightly greater 
Figure I-9. Model results from aggregation effect (Experiment \#3): a) phytoplankton production integrated over the euphotic zone (upper $50 \mathrm{~m}$ ) using nitrate (PNO3; thin dotted line) and ammonium (PNH4; solid line) in $\mathrm{mg} \mathrm{C} \mathrm{m}{ }^{-2}$, where F-ratio (heavy dashed line) is $\mathrm{PNO} /(\mathrm{PNO} 3+\mathrm{PNH} 4) ; \mathrm{b}$ ) phytoplankton (dotted line) and zooplankton (solid line) biomass averaged over upper $50 \mathrm{~m}$ in $\mu \mathrm{mol} \mathrm{C} \mathrm{^{-1 }}$; c) bacterial biomass (solid line) averaged over

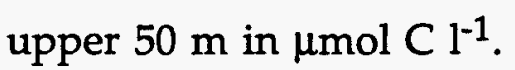


a.

Production with high aggregates

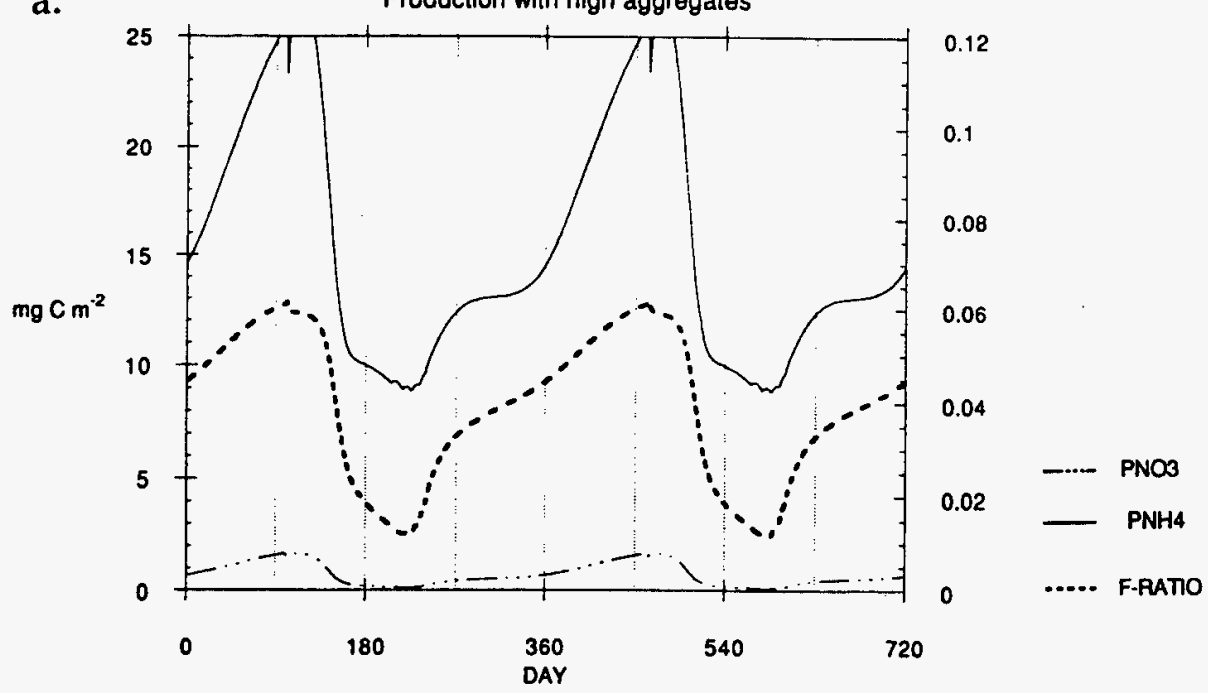

b.

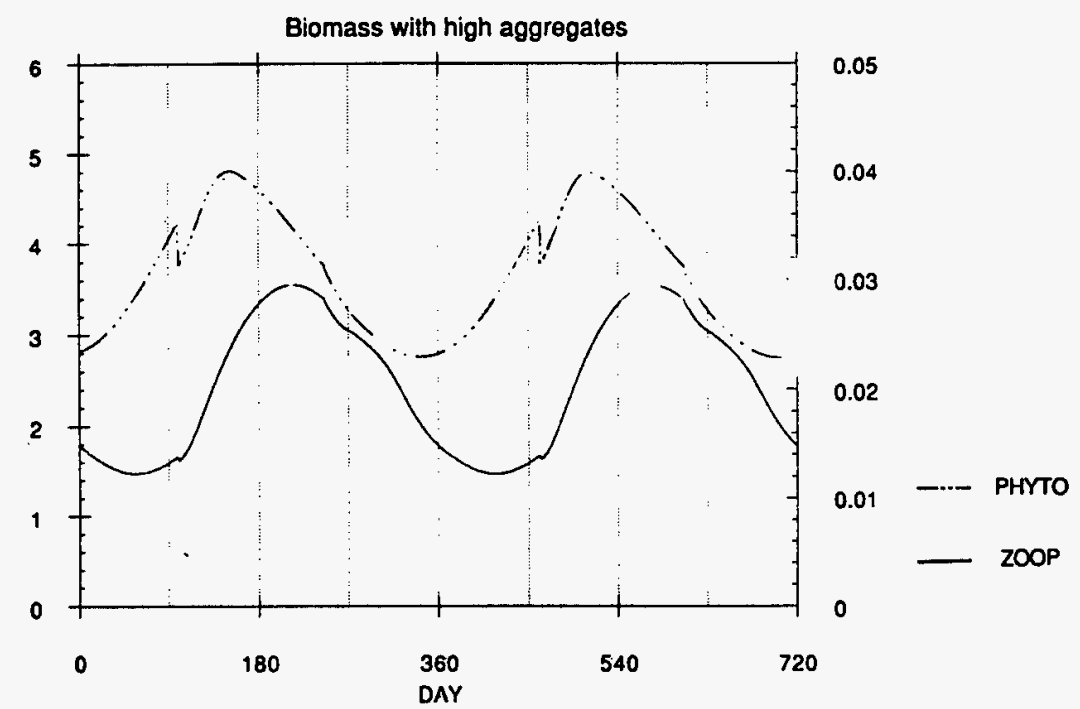

c.

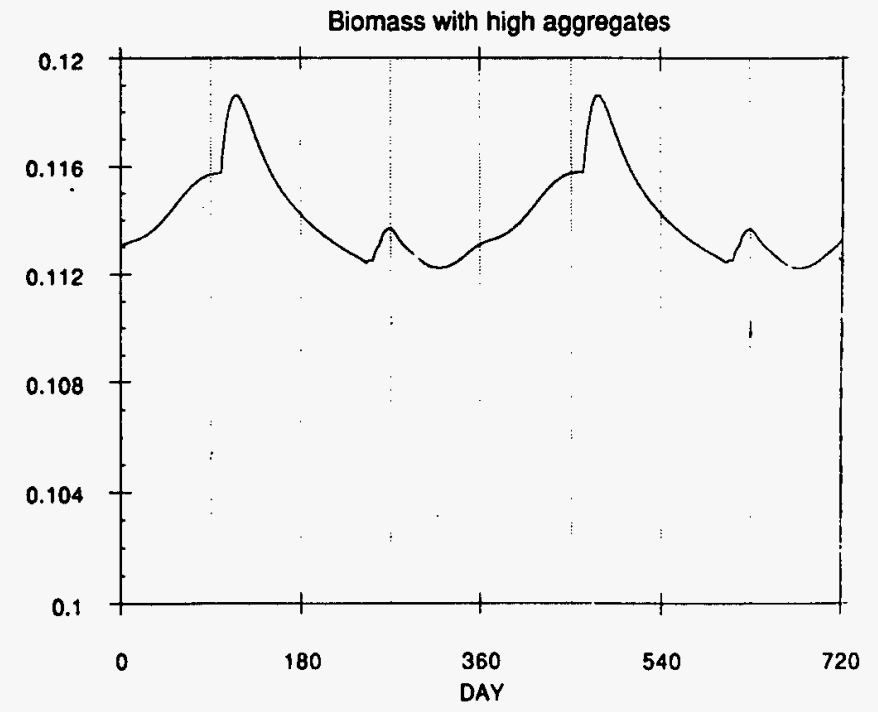


Figure I-10. Model results from increased zooplankton efficiency (Experiment \#4): a) phytoplankton production integrated over the euphotic zone (upper $50 \mathrm{~m}$ ) using nitrate (PNO3; thin dotted line) and ammonium (PNH4; solid line) in $\mathrm{mg} \mathrm{C} \mathrm{m}^{-2}$, where F-ratio (heavy dashed line) is $\mathrm{PNO} /(\mathrm{PNO} 3+$ PNH4); b) phytoplankton and zooplankton biomass averaged over upper 50 $\mathrm{m}$ in $\mu \mathrm{mol} \mathrm{C} \mathrm{l}^{-1}$; and c) bacterial biomass (dotted line) integrated over upper $50 \mathrm{~m}$ in $\mu \mathrm{mol} \mathrm{C} \mathrm{^{-1 }}$. 
a.

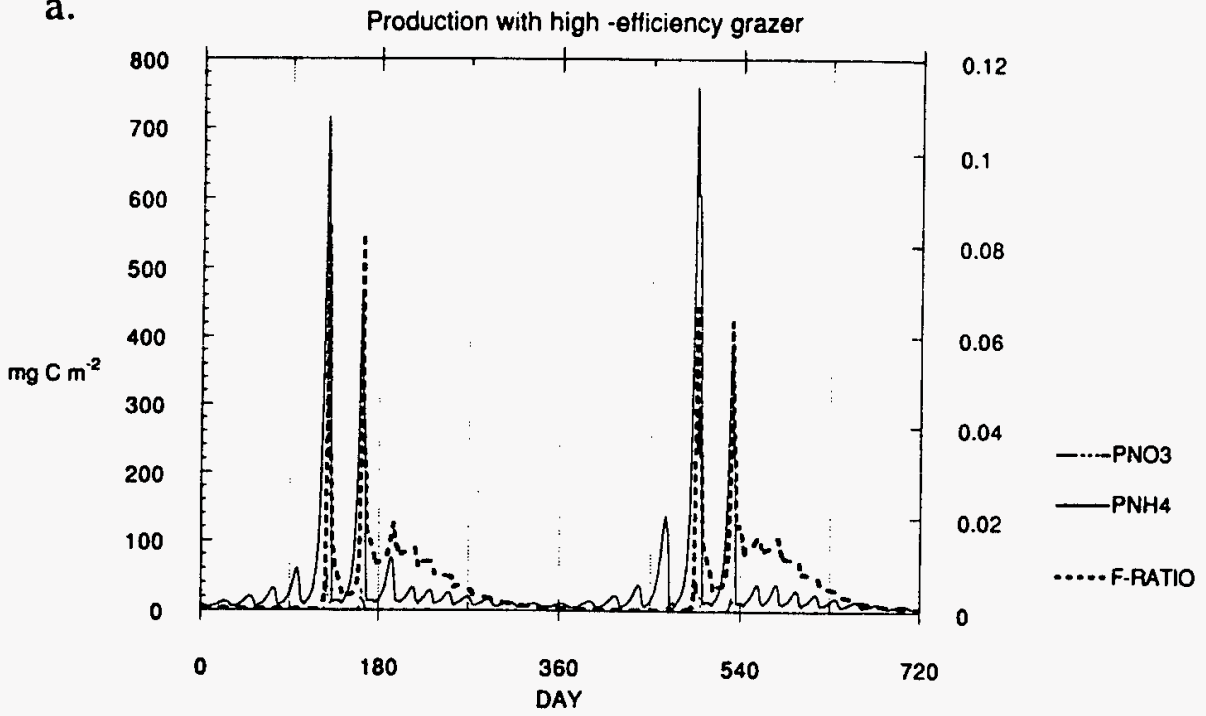

b.

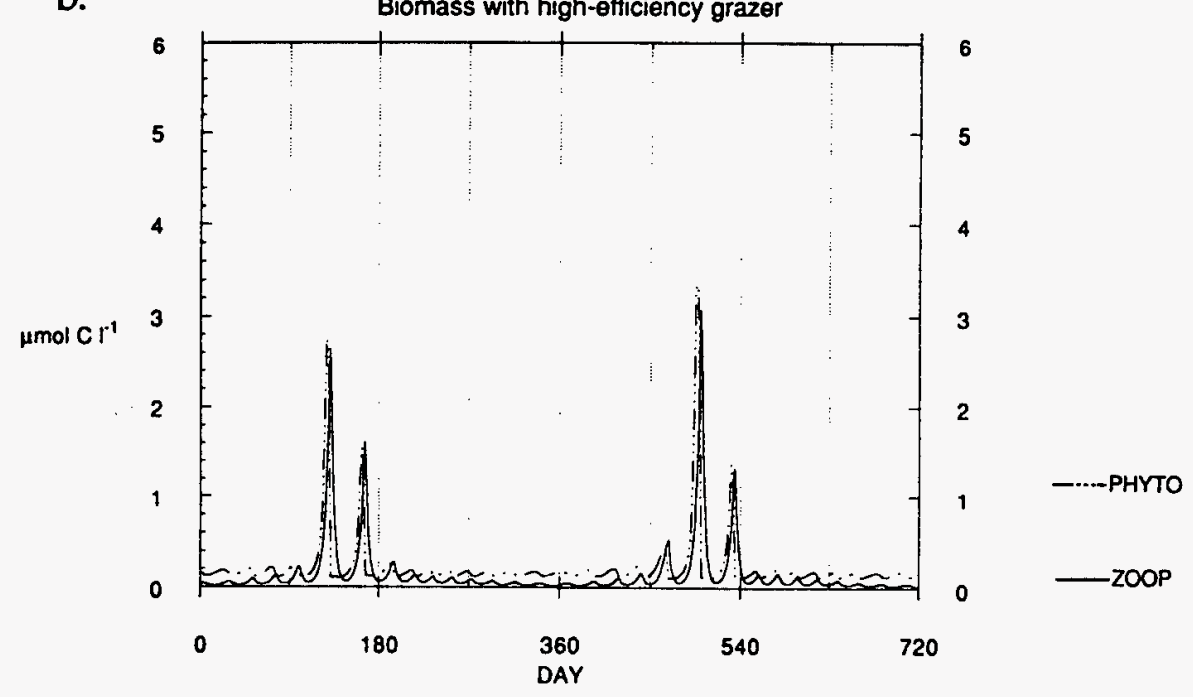

c.

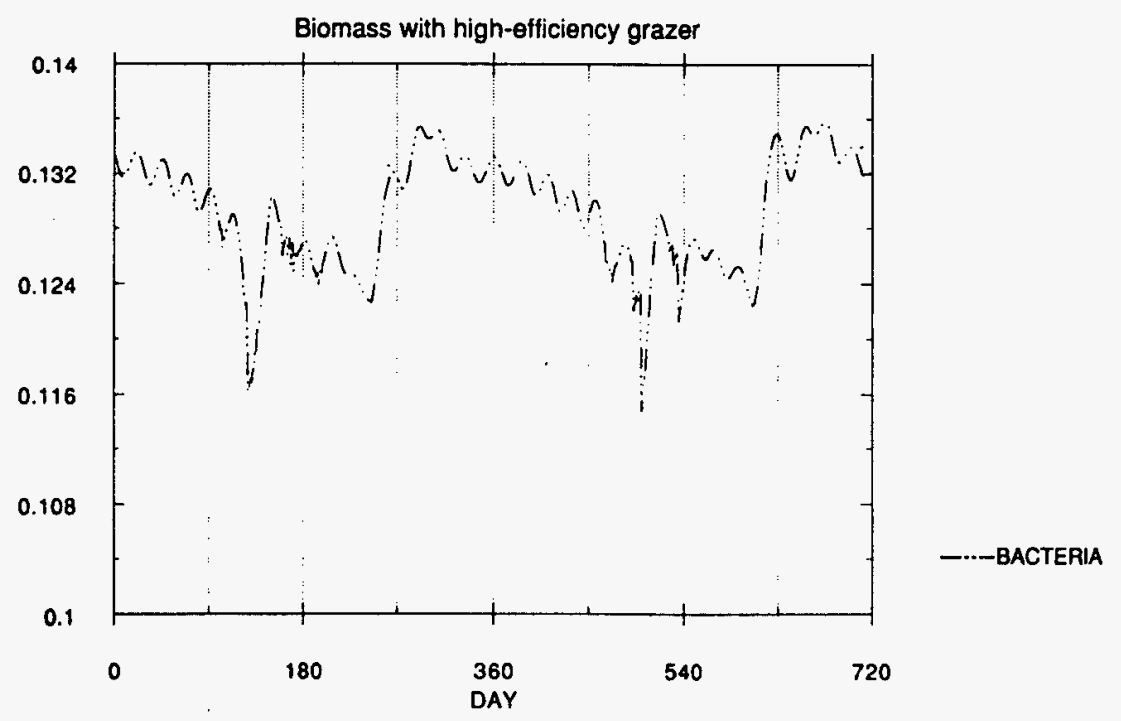


42

a.

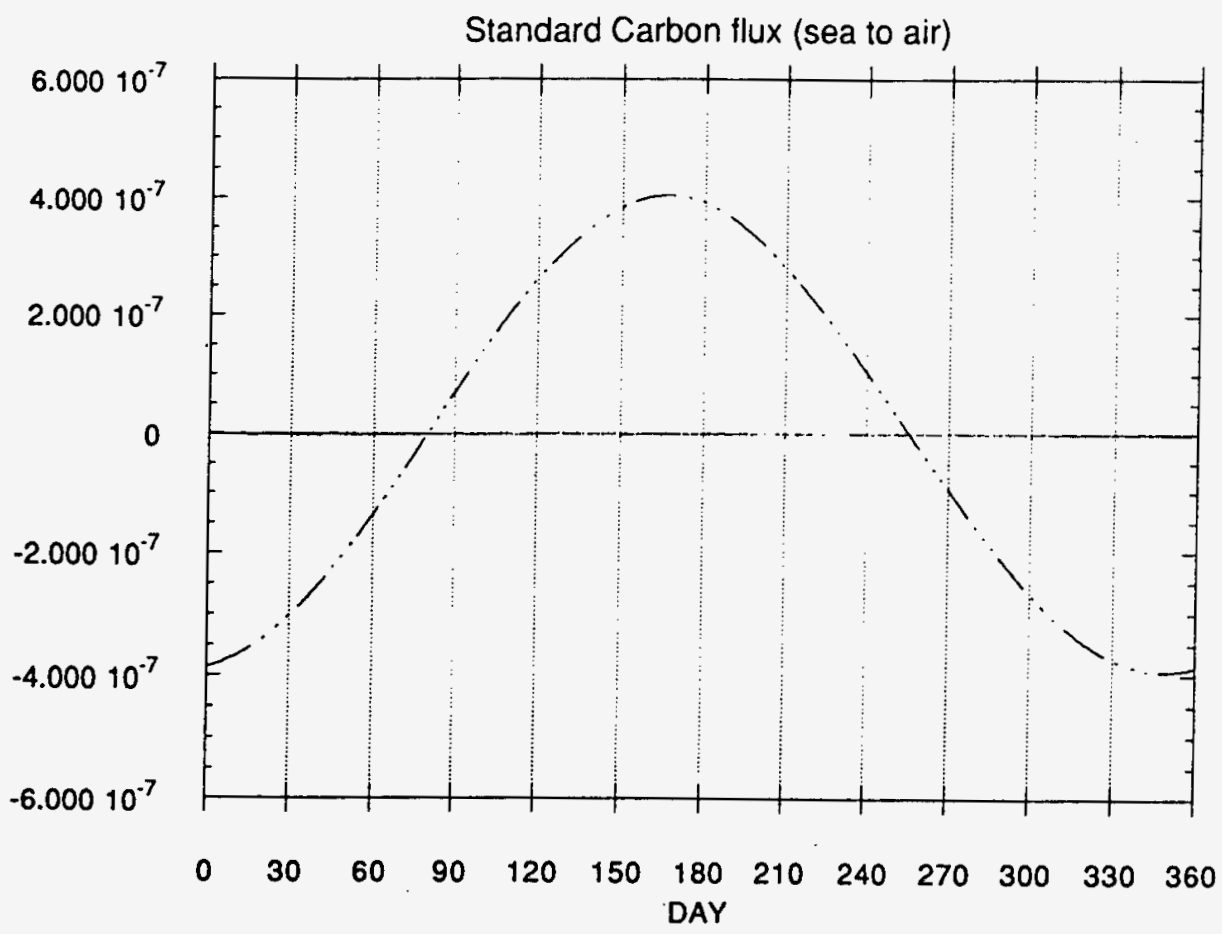

b.

Carbon flux sea-to-air with high-efficiency grazer

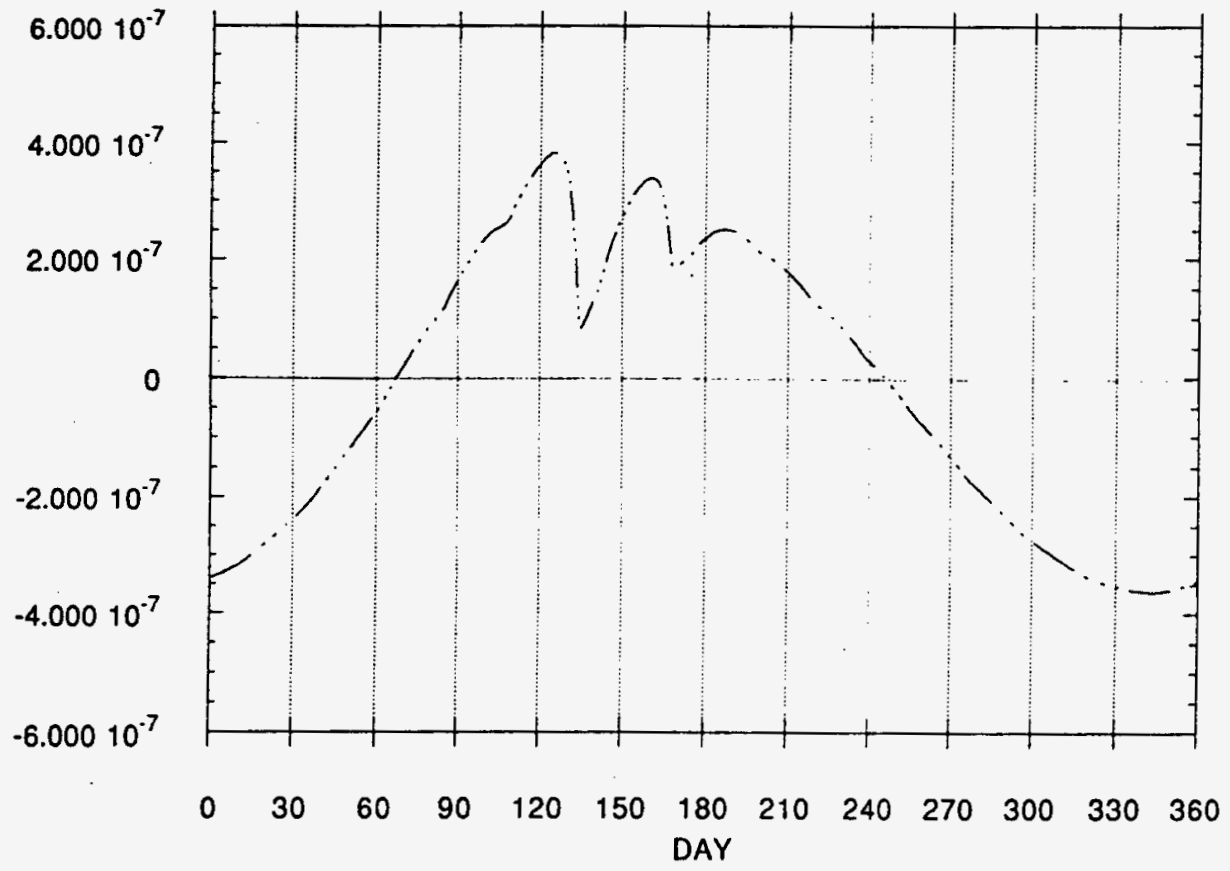

Figure I-11. Comparison of model results for annual carbon flux $\left(\mathrm{mol} \mathrm{C}^{-1}\right)$, where positive values indicate flux from ocean to atmosphere: a) Standard model; and b) Experiment \#4. 


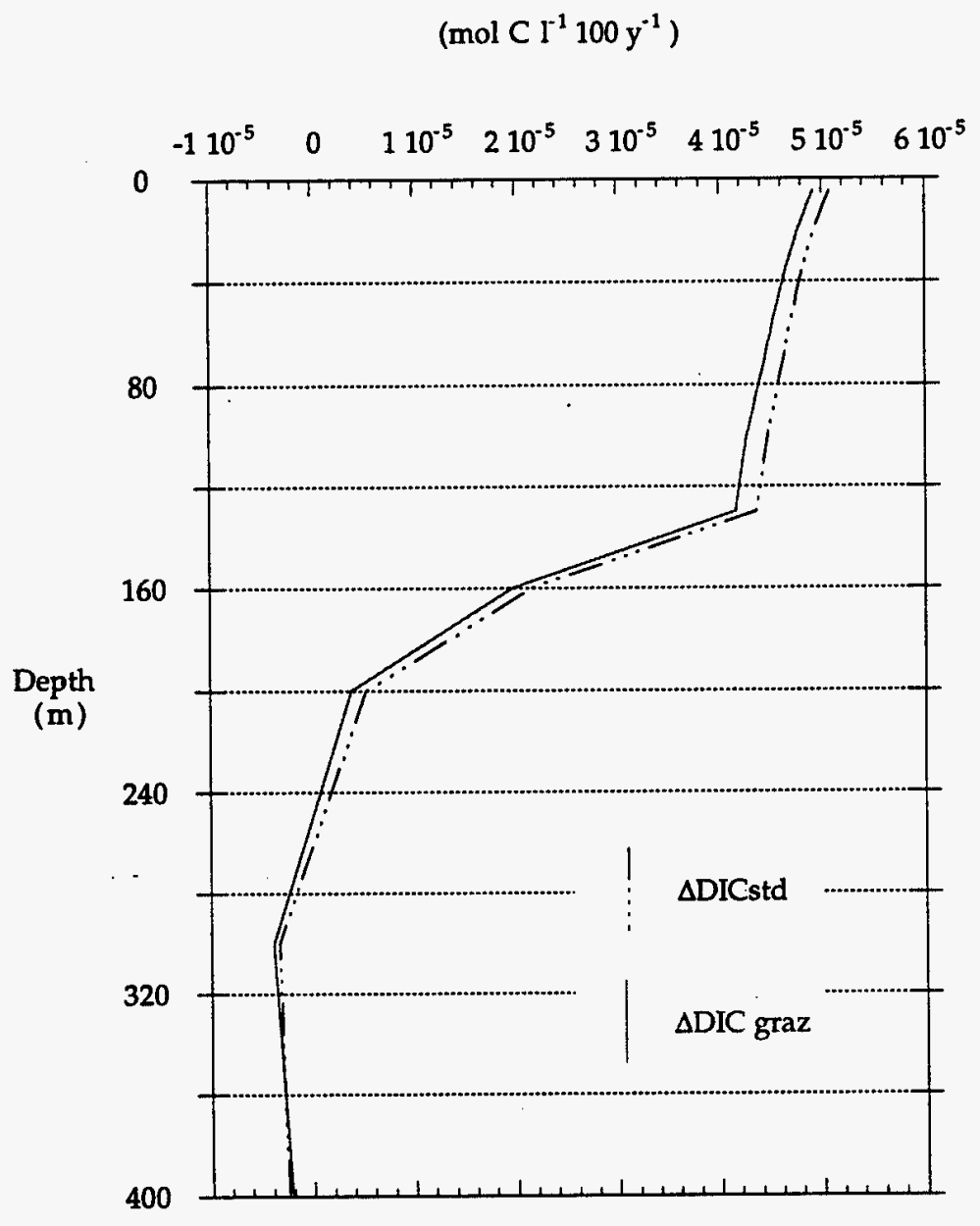

Figure I-12. Model-generated oceanic uptake of atmospheric $\mathrm{pCO}_{2}$ increase of one-percent-per-year as a function of depth $(\mathrm{m})$, where $\triangle \mathrm{DIC}$ (dotted line) indicates the perturbation response (excess transient $\mathrm{CO}_{2}$ taken up) by standard model (mol C $\mathrm{l}^{-1} 100 \mathrm{y}^{-1}$ ), and $\triangle \mathrm{DIC}$ graz (solid line) is the perturbation response of the Experiment \#4 model (mol C $\left.\mathrm{l}^{-1} 100 \mathrm{y}^{-1}\right)$. 
uptake. Given this result, we must conclude that episodic events in our model (patterned after the subarctic Pacific) have no long term impact on the uptake of the transient $\mathrm{CO}_{2}$ signal. As recounted below, flaws or limitations of this overall preliminary exercise, however, leave the question open.

\section{Conclusions and future plans}

Our initial attempt to investigate the influence of marine biology on oceanic $\mathrm{CO}_{2}$ uptake, using a more complex biological scheme than most geochemical models, showed that nonlinear biological responses influence short-term but not long-term oceanic uptake of $\mathrm{CO}_{2}$. The model showed sensitivity to some changes in the partitioning of carbon and rates of recycling. More work is needed to completely understand these sensitivities. Episodic events do show strong impacts on the flux of $\mathrm{CO}_{2}$ between the ocean and the atmosphere. This result should be kept in mind when measurements of $\mathrm{pCO}_{2}$ are made by oceanographers over short time scales. Even small changes in biological community structure can impact the shortterm flux of $\mathrm{CO}_{2}$ to and from the ocean.

Our hypothesized change in the long-term (100-y) behavior of oceanic $\mathrm{CO}_{2}$ uptake and the anthropogenic transient due to biology was not detected. This result suggests that biological processes may not influence long term anthropogenic carbon uptake. Absence of evidence, however, does not indicate evidence of absence; there are several alternative explanations, particularly in light of certain problems with the initial model: 1) No long term sinks exist in the model; carbon mixes down to the bottom of the onedimensional ocean and then mixes up again. With such a simple ocean, having no advection or even local sediment sinks, there was in fact no place 
for carbon to be sequestered. 2) The diffusion coefficients used in the model were too low; although steady state was observed in the surface ocean after $300 \mathrm{y}$, the deep ocean may not have been at equilibrium. There was no penetration of the 100-y carbon transient below about $300 \mathrm{~m}$ (see Fig. I-12); this might have been improved by increased diffusive exchange. 3) This is not a high-latitude ecosystem model; significant carbon export is not expected in the sub-arctic Pacific. We need to better constrain some of the parameters to better represent unique export-related aspects of the Arctic, both hydrographical and biological. 4) The ecosystem part of the model is oversimplified in the areas we most expect to have an effect, particularly zooplankton. 5) With only a small number of sensitivity tests, we do not have a complete picture of the nonlinear behavior of the model; feedbacks between changes in more than one parameter could affect the short-term carbon flux enough to change long-term carbon uptake to a level we can resolve. The most obvious improvements, therefore, would be to add a sink term (either through episodic advection or sedimentation), increase the diffusion coefficients, improve the biological model with aspects of high latitude biota highlighted in other chapters of this dissertation, and run a more complete sensitivity analysis.

Given the observed model sensitivity to grazer parameters and the apparent importance of bacterivory observed in the NEW Polynya (Ch. 3-4), a major improvement to the biological model would be to separate bacterivores from herbivores so that the microbial loop can function distinctly from the herbivorous food web. Recent developments suggest that protozoa, and not bacteria, may be responsible for much of the remineralization that occurs in the ocean (Berman, 1991; Caron, 1991). Add this effect to their apparent 
control over bacterial activity in some high-latitude environments, and the importance of protozoa cannot be underestimated.

For my postdoctoral research at the University of Georgia (with Drs. R. G. Wiegert and L. R. Pomeroy), I plan to become more familiar with ecosystem modeling techniques used by ecologists to better represent and analyze the role of biological complexity. I want to use these techniques to improve the existing model, initially making it more diagnostic in order to determine the acceptable level of ecosystem simplicity that could be incorporated into more complex ocean-atmosphere models. The combination of traditional oceanographic modeling techniques with those learned from ecologists may provide unique insight. Once a reasonable sink term and protozoa are added to the model, my goals are, first, to continue to perform sensitivity analyses and test for the impact of episodic and nonsteady-state biological processes on short-term (days to seasons) as well as long-term (annual to decadal) carbon inventories and, second, to examine how the structure of an ecosystem can influence the flux of carbon (e.g., Boyd and Newton, 1995; see also, for example, the discussion in Legendre and Rassoulzadegan, 1994, on herbivorous food webs versus microbial loops). Ultimately, the improved model could be used to predict the perturbation response of high-latitude ecosystems to increased anthropogenic carbon and ocean temperature. The results should prove useful to global carbon cycle modelers interested in how sensitive results are to the parameterization of marine biological processes. 


\title{
III. Pelagic Microbial Activity in the Northeast Water Polynya: \\ TESTING FOR TEMPERATURE AND SUBSTRATE INTERACTIONS \\ Using A Kinetic APPRoACH.
}

\begin{abstract}
Previous research in high-latitude oceans has sometimes revealed a decoupling between phytoplankton and bacterial processes which could enhance vertical fluxes significant to global carbon cycling. A
\end{abstract} disproportionately negative effect of low temperature on the bacteria has been offered as a possible explanation. Pure cultures of marine bacteria have shown an enhanced substrate requirement at low temperatures, suggesting that cold-water bacteria may underutilize substrate pulses and thus enhance carbon export. To test these hypotheses, we used ${ }^{14} \mathrm{C}$-amino acids and a kinetic approach with natural populations of pelagic Arctic bacteria during the summertime 1992 and 1993 expeditions to the Northeast Water Polynya. We also obtained and examined other data from the study region, including organic matter and chlorophyll a concentrations, bacterial abundance, size, and potential growth rates over a range of temperatures, to assist interpretation of the kinetics data. Results analyzed using multivariate ANOVA showed that added substrate concentration had a significant effect on utilization rates at all stations, but only some stations in the polynya showed a significant temperature effect. Interactions between temperature and substrate were detected only rarely. Values computed for the dimensionless ratio $\left(P^{*}\right)$ of cell-specific diffusive flux to maximum uptake velocity suggested that the bacteria were not diffusion limited in this sub-zero environment, although this conclusion was sensitive to assumptions about 
the percentage of metabolically active cells. Contrary to prediction, measurements of specific affinity $\left(a_{A}^{0}\right.$, sensu Button), maximum utilization rate $\left(V_{\max }\right)$, and half-saturation concentration $\left(K_{t}\right)$ revealed mixed responses to temperature depending on station location, with extremely psychrophilic behavior observed at stations most likely to be influenced by direct Arctic ocean outflow. Unusually large cells were also observed and argued to be consistent with both low substrate concentration and grazing pressures on these organisms. The observed heterogeneity in sensitivity to temperature, within a relatively small and well-defined ecosystem such as the polynya, implies the need for improved understanding of phenotypic and genotypic microbial diversity of psychrophiles before we can generalize or predict the role of temperature in high-latitude carbon export.

\section{Introduction}

For a seasonally ice-covered marine ecosystem to function as a sink for atmospheric carbon, net autotrophy must exceed net heterotrophy during the times when surface waters are free of ice and open to air-sea gas exchange (Yager et al., 1995). Of interest are the mechanisms by which such a condition may occur and whether or not these mechanisms are sensitive to warming. Pomeroy and co-workers have consistently recorded a de-coupling between phytoplankton and bacterioplankton activity in the high-latitude environments they have examined (Pomeroy and Deibel, 1986; Pomeroy et al., 1990; Pomeroy and Wiebe, 1988; Pomeroy and Wiebe, 1993), suggesting that polar waters may provide more carbon and energy to higher trophic levels because bacteria are disproportionately affected by low temperature compared to autotrophs. Depending on the activities of the higher trophic 
levels, this hypothesis can also be invoked to explain why polar oceans may function as efficient biological pumps (Ashjian et al., 1995). The possibility that the situation could change with predicted warming at high latitudes (Hansen et al., 1984) and cause a feedback to atmospheric carbon levels has stimulated much research in these regions (Smith et al., 1990).

Further research by Pomeroy and co-workers suggests that the bacterial limitation occurs at the level of substrate uptake. In the field, they observe a connection between in situ temperature and required food concentrations for growth (Pomeroy et al., 1991); from studies of laboratory cultures they conclude that mesophilic (moderate temperature-loving) and psychrotolerant (cold-tolerant) bacterial isolates from cold environments have enhanced substrate requirements at low temperatures (Wiebe et al., 1992; 1993) but grow equally well on any substrate concentration if warmed. The response of psychrophiles (cold-loving bacteria) appears more complicated (Pomeroy et al., 1995), motivating the need to better understand the phenotypic and genotypic diversity of indigenous polar microbes.

Independent tests of the decoupling hypothesis have yielded mixed results, undoubtedly due in part to the potential for very different types of microbial communities to exist in each test environment (Baross and Morita, 1978 ; DeLille et al., 1988), the myriad of techniques used to measure activity, and the range in temporal and spatial scales over which the activity has been measured. Also unclear is the importance of grazing pressure on the bacteria (Billen and Becquevort, 1991; Kuparinen and Bjørnsen, 1992a; Moisan et al., 1991; Putt et al., 1991) and the potential response of bacterivores to low temperature (Choi and Peters, 1992). 
A common method for assessing substrate dependence of bacteria is to use phytoplankton biomass (e.g. chlorophyll $a$ concentration) or production as a proxy for bacterial substrate. This assumes a direct coupling between the availability of utilizable dissolved organic matter (UDOM) for the bacteria and its ultimate source, primary production. Most of the temperate ocean seems to satisfy this assumption reasonably well, as exemplified by a positive linear relationship between chlorophyll $a$ concentration and bacterial abundance and also between net primary production and bacterial production (Ducklow and Carlson, 1992). There are indications, however, that not all polar environments follow the same pattern as the temperate ocean or as each other.

In keeping with the temperate model, some polar regions do show a significant positive correlation between phytoplankton production and bacterial production (Kuparinen and Bjørnsen, 1992b; Li and Dickie, 1987; Sullivan et al., 1990). Some sea-ice microbial communities also show good correspondence between the temperature ranges for maximal growth rate of both autotrophs and heterotrophs (Kottmeier and Sullivan, 1988) and a good correlation between the timing of bacterial growth and that of ice-algal production (Smith et al., 1989).

In other polar regions, including the Northeast Water (NEW) Polynya where we worked, the coupling between bacteria and phytoplankton is either different from the temperate standard (Karl et al., 1991; Rivkin et al., 1991; Smith et al., 1995) or missing altogether (Billen and Becquevort, 1991). In these cases, the mechanism explaining poor or absent coupling may not be a disproportionate response to low temperature but rather a temporal or spatial disconnect between phytoplankton production and the generation of UDOM 
for the bacteria (Billen, 1990), although such a lag is not always observed (Thingstad and Martinussen, 1991). For example, the generation of UDOM may be delayed if cells are not "leaky" (e.g. Hellebust, 1965), if there are few herbivores present to generate UDOM by sloppy feeding or incomplete digestion (e.g. Fuhrman, 1987), or if cells aggregate or colonize and sink rapidly from the surface waters (Wassman et al., 1990). Also, contrary to prediction, limitations on bacterial abundance in these cases appear at higher chlorophyll $a$ concentrations ( $\geq 2.5 \mu \mathrm{g} \mathrm{Chl} a 1^{-1}$; Karl et al., 1991) rather than at lower chlorophyll $a$ concentrations where the pure culture data suggest it should be.

In questioning the biological basis for disproportionate temperature effects at low temperatures, Jumars et al. (1993) analyzed the diffusive flux of dissolved organic matter (DOM) to free-living osmotrophs over a range of cell sizes. They predicted that an enhanced substrate requirement by bacteriasized cells at low temperature may be due simply to diffusional effects, since low temperature can reduce the diffusive flux of substrate to the cell surface (through its effect on the seawater viscosity and the diffusion coefficient). Bacteria can maximize this diffusive flux in two ways: increase cell size (since flux increases linearly with cell radius) to a point where the marginal gains of being larger exceed the costs (Jumars, 1993) or maintain the maximum gradient in substrate between cell surface and external medium by keeping cell-surface concentration at zero. Diffusion limitation occurs when the cell is able to maintain surface concentration at zero, but the magnitude of the diffusive flux to the cell is less than the rate of substrate transport across the cell membrane. The extent of diffusion limitation is described by a dimensionless ratio of these two rates ( $\mathrm{P}^{*}$; Pasciak and Gavis, 1974) which can 
also be considered a mass Biot number (e.g. a ratio of two mass transport rates; (Carberry, 1976).

In the absence of diffusion limitation, the ability to take up substrate depends on the membrane transport systems of the cell and will thus rely on transporter density and capacity as described by kinetic parameters of specific affinity, $a_{A}^{o}$, and maximum uptake velocity, $V_{\max }$ (Button, 1985). Specific affinity is perhaps the most direct way to test for substrate limitation since it directly reflects the responsiveness of cells to small increases in substrate concentration.

In this study, we used a kinetic approach with ${ }^{14} \mathrm{C}$-amino acids to test for temperature effects on $a_{A}^{o}, V_{\text {max }}$, and $P^{*}$, as determined for natural populations of pelagic bacteria living in the moderately productive, low temperature Arctic coastal environment of the NEW Polynya. To assist in interpreting the kinetics results, we also examined concentrations of natural substrates, chlorophyll $a$, and bacteria throughout the study area, and determined median cell size and temperature optima for potential growth rates at selected stations. As "the science that relates microbial growth rates to the nutrient concentrations on which they depend" (Button, 1985), kinetics can be divided into a two step process: the concentration-limited utilization of nutrients and the efficiency with which those nutrients translate into growth (Button, 1985). We address the first process in this chapter (Yager and Deming, in prep); discussion of growth efficiency in this environment will follow (Chapter 4; Yager and Deming, in prep.). 


\section{Methods}

\section{Sample collection}

The Northeast Water (NEW) Polynya on the continental shelf of Northeast Greenland (Fig. III-1) was the site of a major international and multi-disciplinary study during the summers of 1992 and 1993 (NEWater Investigators, 1993; Overland et al., 1995; Hirche and Deming, in press). Samples were collected during both cruises of the USCGC Polar Sea (July 15 August 15, 1992; July 18 - August 18, 1993) and one leg of the FV Polarstern cruise in 1993 (ARKIX/2, May 20-June 29). Unless otherwise stated, water samples were recovered in Niskin bottles from near-surface fluorescence maxima, as measured by a SeaTech fluorometer attached to the CTD, from a depth range of 0 to $60 \mathrm{~m}$ (Fig. III-1; Table III-1). Samples were removed carefully to sterile polyethylene containers immediately upon arrival on deck and stored in a $-1^{\circ} \mathrm{C}$ waterbath. All manipulations with live samples, prior to experimental incubations in temperature-controlled waterbaths, were carried out using ice/seawater baths to keep samples at $-1^{\circ} \mathrm{C}$ at all times. This effort was assisted by performing all operations (except open-container radioisotope handling on board Polarstern) inside refrigerated $\left(0-2^{\circ} \mathrm{C}\right)$ laboratory vans. Water samples were not prefiltered prior to incubation so as not to introduce artifacts in DOM concentrations (Carlson et al., 1996).

\section{Substrate availability}

Subsamples were taken for dissolved free amino acids (DFAA), dissolved organic carbon (DOC), and total organic carbon (TOC). DFAA concentrations were measured using high-performance liquid 


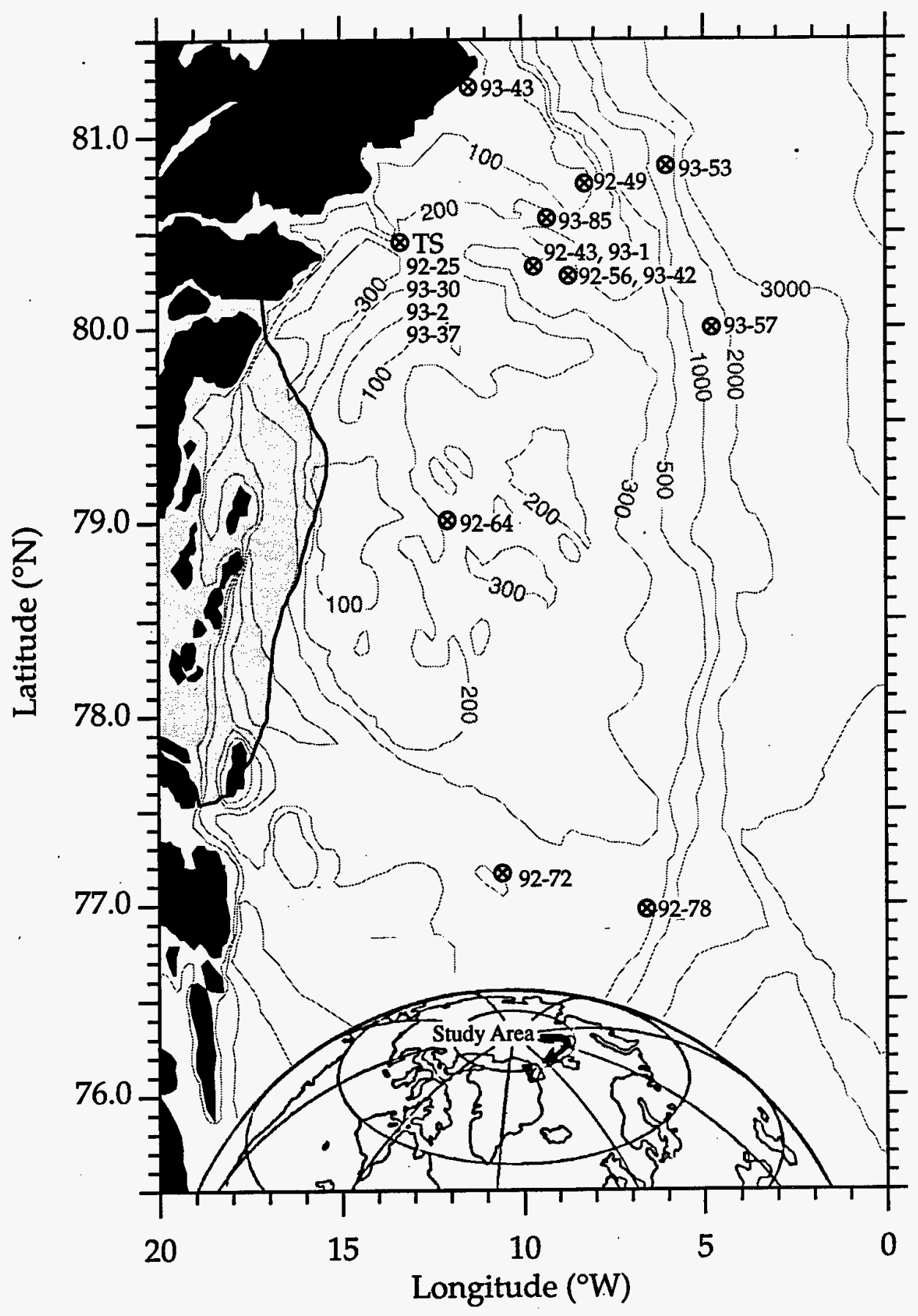

Figure III-1. Map of the Northeast Water Polynya with station locations for microbiological experiments. Depth contours in meters. Station numbers from each cruise are shown preceded by the last two digits of the year they were sampled. Several locations, including the time series location (TS), were sampled multiple times during the two field seasons (see Table III-1 for individual station information). 
Table III-1: NEW Polynya station information for microbiological samples.

\begin{tabular}{|c|c|c|c|c|c|c|c|c|c|c|}
\hline Station & $\begin{array}{c}\text { Date } \\
\text { sampled }\end{array}$ & $\begin{array}{l}\text { Latitude } \\
\text { (N.) }\end{array}$ & $\begin{array}{l}\text { Longitude } \\
\text { (W.) }\end{array}$ & $\begin{array}{l}\text { Sample } \\
\text { depth } \\
\text { (m) }\end{array}$ & BNLID $^{a}$ & $\begin{array}{l}\text { In situ } \\
\text { Temp. } \\
\left({ }^{\circ} \mathrm{C}\right)\end{array}$ & Salinity & $\begin{array}{l}\text { DFAA }^{b} \\
\text { (nM) }\end{array}$ & $\begin{array}{l}\text { Bacteria } \\
\times 10^{7} 1^{-1} \\
( \pm 1 S E)^{c}\end{array}$ & $\begin{array}{c}\text { FDC }^{d} \\
(\% \pm 1 \mathrm{SE})^{c}\end{array}$ \\
\hline $92-25 A^{e}$ & $7 / 26 / 92$ & $80^{\circ} 26.56^{\prime}$ & $13^{\circ} 19.89^{\prime}$ & 16 & 394 & 0.266 & 32.316 & 67 & $5.01(1.59)$ & $1.30(0.57)$ \\
\hline $92-25 \mathrm{~B}^{e}$ & $7 / 28 / 92$ & $80^{\circ} 27.15^{\prime}$ & $13^{\circ} 23.04^{\prime}$ & 25 & 476 & -1.087 & 32.322 & 86 & $6.91(0.33)$ & $2.63(0.48)$ \\
\hline $92-43 A$ & $7 / 31 / 92$ & $80^{\circ} 18.71^{\prime}$ & $9^{\circ} 41.87^{\prime}$ & 38 & 733 & -1.477 & 32.334 & 31 & $9.75(1.21)$ & $2.93(0.77)$ \\
\hline $92-43 B$ & $8 / 1 / 92$ & $80^{\circ} 17.80^{\prime}$ & $9^{\circ} 25.55^{\prime}$ & 17 & 804 & -1.308 & 31.770 & 47 & $6.30(2.95)$ & $1.56(0.65)$ \\
\hline $92-49$ & $8 / 5 / 92$ & $80^{\circ} 46.20^{\prime}$ & $8^{\circ} 10.86^{\prime}$ & 50 & 880 & -1.344 & 31.901 & 63 & $5.15(0.70)$ & $2.83(0.32)$ \\
\hline $92-56$ & $8 / 7 / 92$ & $80^{\circ} 15.82^{\prime}$ & $8^{\circ} 40.02^{\prime}$ & 16 & 985 & -1.390 & 78 & 143 & $3.93(1.10)$ & $1.98(1.09)$ \\
\hline $92-64$ & $8 / 9 / 92$ & $79^{\circ} 01: 34^{\prime}$ & $12^{\circ} 02.98^{\prime}$ & 27 & 1115 & -1.552 & 31.997 & - & $5.15(0.80)$ & 1.45 (1.32) \\
\hline $92-72$ & $8 / 12 / 92$ & $77^{\circ} 08.23^{\prime}$ & $10^{\circ} 32.84^{\prime}$ & 252 & 1257 & +1.317 & 34.870 & ND & $2.63(0.34)$ & $1.37(1.87)$ \\
\hline $92-78$ & $8 / 14 / 92$ & $76^{\circ} 59.28^{\prime}$ & $6^{\circ} 34.53^{\prime}$ & 230 & 1375 & +1.441 & 34.884 & ND & $4.12(0.27)$ & $1.34(0.70)$ \\
\hline $93-30^{e}$ & $5 / 30 / 93$ & $80^{\circ} 26.34^{\prime}$ & $13^{\circ} 38.66^{\prime}$ & of & NA & -1.700 & 32.310 & - & - & - \\
\hline $93-43$ & $6 / 5 / 93$ & $81^{\circ} 15.00^{\prime}$ & $11^{\circ} 30.00^{\prime}$ & 26 & NA & -1.570 & 31.580 & {$[108: 6.4]$} & - & - \\
\hline 93-85 & 6/14/93 & $80^{\circ} 35.00^{\prime}$ & $9^{\circ} 22.00^{\prime}$ & 58 & NA & -1.620 & 32.060 & {$[94: 5.12]$} & - & - \\
\hline $93-1$ & $7 / 23 / 93$ & $80^{\circ} 19.38^{\prime}$ & $9^{\circ} 45.36^{\prime}$ & 20 & 3024 & -1.404 & 32.313 & - & 6.728 & 1.618 \\
\hline $93-2^{e}$ & $7 / 23 / 93$ & $80^{\circ} 26.40^{\prime}$ & $13^{\circ} 20.58^{\prime}$ & 12 & 3047 & -1.194 & 32.237 & - & 6.368 & 2.278 \\
\hline $93-37^{e}$ & $7 / 30 / 93$ & $80^{\circ} 26.70^{\prime}$ & $13^{\circ} 19.98^{\prime}$ & 14 & 3638 & -1.621 & 32.252 & - & 5.50 & 4.26 \\
\hline $93-42$ & $8 / 1 / 93$ & $80^{\circ} 16.14^{\prime}$ & $8^{\circ} 57.00^{\prime}$ & 23 & 3808 & -1.331 & 32.289 & - & 8.36 & 4.09 . \\
\hline $93-53$ & $8 / 3 / 93$ & $80^{\circ} 49.86^{\prime}$ & $6^{\circ} 00.06^{\prime}$ & 14 & 3988 & -1.148 & 31.208 & - & $11.3^{8}$ & 3.358 \\
\hline $93-57$ & $8 / 4 / 93$ & $79^{\circ} 58.68^{\prime}$ & $4^{\circ} 44.16^{\prime}$ & 13 & 4084 & -1.330 & 31.032 & - & 17.3 & 3.26 \\
\hline
\end{tabular}

a. Brookhaven National Laboratory Identification bottle number, used throughout both Polar Sea cruises. NA = not applicable: samples collected aboard FV Polarstern, no ID\# associated with bottle.

b. DFAA concentrations except for [ ] values at Polarstern stations which are DOC:DON values in $\mu \mathrm{M} ; \mathrm{ND}=$ not detected; - = samples lost. c. Standard errors calculated from counts on up to three replicate samples in 1992. Standard errors not available for $1993 ; n=1$.

d. FDC is Frequency of Dividing Cells, or cells showing fractional septa, as seen under epifluorescence microscope and Acridine orange stain.

$e$. Time-series location; A and B refer to repeated visits to same location.

f. Sample collected using tripod-mounted Niskin bottle from just under ice after drilling.

g. Bacterial count made from sample taken by different Niskin bottle at approximately the same depth, time, and location. 
82

chromatography (HPLC; Cowie and Hedges, 1992) on seawater samples that had been filtered ( $0.2 \mu \mathrm{m}$ cellulose acetate; Corning), acidified using $100 \mu \mathrm{l}$ double-distilled $\mathrm{HCl}$, and then stored refrigerated until processed in Seattle. TOC (unfiltered) and DOC (filtered as above) samples were collected into muffled glass scintillation vials ( $20 \mathrm{ml}$ ), acidified with $50 \mu \mathrm{H}_{3} \mathrm{PO}_{4}$ (in 1992) or $50 \mu \mathrm{l}$ double distilled $\mathrm{HCl}$ (in 1993), capped with Teflon septa which had been rinsed with acetone, and then frozen for processing in Seattle using Shimadzu TOC-5000 Total Organic Carbon Analyzer. Chlorophyll a concentrations from the 1992 and 1993 Polar Sea cruises are available in data reports (Wallace et al., 1995a; 1995b), accessible via the National Technical Information Service (U.S. Dept. of Commerce) or the NSDIC database and summarized for 1992 in the literature (Smith et al., 1995).

\section{Bacterial abundance and cell size}

Subsamples were fixed with $2 \%$ formaldehyde and kept cold and in the dark until processed in Seattle. Samples were filtered onto Irgalan-black 0.2$\mu \mathrm{m}$ Nuclepore filters, stained with both DAPI (0.002\%) and Acridine Orange (AO; 1\%), and counted using epifluorescence microscopy (Relexans et al., in press; this approach uses AO to count and DAPI to confirm). The frequency of dividing cells was also noted during counting.

Cell size was determined for 20 samples from the times-series station $\left(80^{\circ} 26^{\prime} \mathrm{N}, 13^{\circ} 20^{\prime} \mathrm{W}\right.$, Sta. $92-25$ and $\left.93-37\right)$ by measuring with calipers the length and width of at least 100 photographed cells stained with $A O$ and projected onto a flat white surface (Lee and Fuhrman, 1987). A crosscalibration was done as above using fluorescent $5-\mu \mathrm{m}$ microspheres. Biovolumes were calculated assuming cells were either coccoid $\left[4 / 3 \pi r^{3}\right.$, 
where $r$ is radius) or rod-shaped $\left(\pi(W / 2)^{2} L\right)+4 / 3 \pi(W / 2)^{3}$, where $W$ is the width and $L$ is the length of the cell). Cell sizes for both rods and cocci measured from a single sample exhibited distinctly non-normal frequency distributions, so medians, rather than means were computed. The cell volume for each sample was determined by combining the frequencyweighted median volumes of cocci and rods. The 20 medians were normally distributed, so from them we could compute a mean (average) cell size for all samples.

Encounter probabilities between bacteria and potential predators were estimated with coagulation theory according to Jumars (1993), using secondorder rate coefficients $\left(K_{i j}\right)$ and contact efficiencies $\left(E_{i j}\right)$ for neutrally buoyant, spherical particles of diameter $d_{i}$ (bacteria as prey) and $d_{j}$ (predator). The mechanisms included in the calculation were 1) Brownian motion without settling and 2) turbulent shear for particles smaller than the Kolmogorov scale (Hill and Nowell, 1990). We assumed a typical turbulent kinetic energy dissipation rate $(\varepsilon)$ of $0.01 \mathrm{~cm}^{2} \mathrm{~s}^{-3}$ (or $10^{-6} \mathrm{~W} \mathrm{~kg}^{-1}$; see review by Yamazaki and Osborn, 1988) and used a typical in situ temperature $\left(-1.5^{\circ} \mathrm{C}\right)$ and salinity $(32 \%)$ from the polynya region to compute dynamic $(\mu)$ and kinematic $(v)$ viscosity (Jumars et al., 1993).

\section{Potential growth rates}

Potential growth rates were determined by measuring changes in the numbers of bacterial cells in organically enriched samples incubated over an 8-d time-course experiment (method modified from Deming, 1985). Two-ml aliquots were distributed into $4-\mathrm{ml}$ sterile plastic test tubes, enriched with 30 $\mathrm{mg} \mathrm{C} \mathrm{l}^{-1}$ yeast extract (DIFCO; final concentration $0.01 \%$ by weight), and 
incubated in the dark in temperature-controlled water baths at $-1.5,2,5,10$, or $20^{\circ} \mathrm{C}$. Additional replicates of the in situ temperature $\left(-1.5^{\circ} \mathrm{C}\right)$ incubations were augmented with $0.002 \%$ nalidixic acid, with or without addition of $0.025 \%$ yeast extract (Kogure et al., 1979), to assess for percent active bacteria. All samples were fixed using $2 \%$ formaldehyde after incubation for $0,2,4$, or 8 $\mathrm{d}$ and kept refrigerated in the dark until processing. All samples were stained and counted using epifluorescence microscopy, as described above.

\section{Kinetics}

To test the temperature sensitivity of substrate uptake kinetics, we measured the utilization of a mixture of uniformly (all carbons) ${ }^{14} \mathrm{C}$-labeled amino acids purchased from New England Nuclear (NEC-445E, L-[ $\left.{ }^{14} \mathrm{C}(\mathrm{U})\right]$ amino acid mixture, $3.80 \mu \mathrm{mol} \mathrm{mCi}^{-1}$ or $218 \mu \mathrm{g} \mathrm{C} \mathrm{mCi}^{-1}$ ) using a method modified from Deming (1993), based on the original method by Wright and Hobbie (1966). The prepared mixture of amino acids we used compares favorably $(r=0.83, P<0.01)$ on a mole $\%$ basis with amino acid compositions of coastal marine phytoplankton (Cowie and Hedges, 1992b). The added concentrations ranged from tracer to saturation levels: $0.5,1,2,5,10,20,50$, or $100 \mathrm{nM}\left(0.03\right.$ to $\left.6 \mu \mathrm{g} \mathrm{Cl}^{-1}\right)$. The range of incubation temperatures $\left(-1.5\right.$ to $\left.5^{\circ} \mathrm{C}\right)$ included and extended slightly beyond that to which organisms were typically exposed in the surface waters of the polynya (range of -1.8 to $3.5^{\circ} \mathrm{C}$ in 1992 , Wallace et al., 1995a; although occasionally the top $2 \mathrm{~m}$ warmed to as much as $6.4^{\circ} \mathrm{C}$ in 1993; Wallace et al., 1995b).

Each experiment involved 18 treatments (six substrate concentrations and three temperatures) with either two or three replicates for each. The rates for each replicate were determined by either time-course (up to seven time 
points including a time zero) or end-point experiments. Time-course experiments were carried out early in the first cruise and then occasionally throughout to determine the best time to use for endpoint experiments. Subsamples were taken by $20-\mathrm{ml}$ increments using a sterilized dispenser (Brinkman Instruments, Inc.; 05-03-040-7) for individual incubations in 50$\mathrm{ml}$, acid-washed, autoclaved, borosilicate glass serum bottles (Kimble, 61000G50). Each sample received a small volume $(0.54 \mathrm{ml})$ of sterile stock solution of mixed amino acids to obtain the desired final concentration. Samples were capped with gray-butyl stoppers (Kimble, 73828-21) and aluminum crimps (Kimble, 73820-20) which allowed for submerged incubation in waterbaths at $-1.5,-1,0,2,3.5$, or $5{ }^{\circ} \mathrm{C}$; the average in situ temperature for the depths sampled was $-1.2^{\circ} \mathrm{C} \pm 0.20$ ( $\pm 2 \mathrm{x}$ standard error; $95 \%$ confidence limit). Samples were incubated in the dark, for 3 to $24 \mathrm{~h}$, but typically about $12 \mathrm{~h}$ for endpoint experiments:

At the end of each incubation (including time-zero and $2 \%$ formaldehyde-killed controls), inorganic carbon was extracted using a method modified from (Hobbie and Crawford, 1969). Bottle caps were replaced with sterile rubber septa (Kontes, 882310-0000) equipped with center wells (Kontes, 882320-0000) containing a fluted, 2- x 5-cm piece of Whatman No. 1 filter paper "wick" saturated with $0.2 \mathrm{ml}$ of the $\mathrm{CO}_{2}$-absorber, phenethylamine (PEA; Sigma Chemical). Control experiments showed no significant $\mathrm{CO}_{2}$ was lost during cap replacement. Once wick and well were in place and sealed with rubber cement, incubations were stopped by injecting $0.4 \mathrm{ml}$ of $4 \mathrm{~N}$ $\mathrm{H}_{2} \mathrm{SO}_{4}$ into the liquid sample to reduce $\mathrm{pH}$ to $<2$. Samples were kept in the dark and gently shaken on a shaker table (ca. $100 \mathrm{rpm}$ ) for at least $1 \mathrm{~h}$ (or for 12 $\mathrm{h}$ without shaking when the shaker table malfunctioned; controls showed no 
difference between these two treatments) to collect the respired ${ }^{14} \mathrm{CO}_{2}$ onto the wick. Following the extraction of ${ }^{14} \mathrm{CO}_{2}$ from the seawater, the Whatman filter paper was transferred to a scintillation vial. $\mathrm{CO}_{2}$ capture efficiency was determined by adding $\mathrm{NaH}^{14} \mathrm{CO}_{3}$ to a series of $0.2-\mu \mathrm{m}$-filtered, sterile seawater samples, incubating over the same range of temperatures for $12 \mathrm{~h}$ in the dark, and extracting $\mathrm{CO}_{2}$ as above. The $86.5 \%$ efficiency we measured $( \pm 5.86 ; 95 \%$ confidence interval based on $n=22$ control samples) agrees with the $86.54 \%$ efficiency reported by (Thompson and Hamilton, 1974) for a similar technique. Extraction efficiency was independent of $\mathrm{CO}_{2}$ concentration and temperature (data not shown).

The ${ }^{14} \mathrm{C}$-labeled cells from the remaining seawater sample were collected onto a $0.2-\mu \mathrm{m}$ Millipore nitrocellulose filter by gentle vacuum filtration. The sample was followed by a $40-\mathrm{ml}$ rinse of $0.2-\mu \mathrm{m}$ filtered seawater of the same salinity. The filters were transferred to a scintillation vial; all filters were allowed to air-dry before scintillation cocktail (Ecolume) was added. Counts were performed $12 \mathrm{~h}$ after addition of cocktail on Beckman scintillation counters, using standard curves and H\# corrections to account for quench. Total utilization was determined by adding together the radiolabeled carbon respired (on the Whatman filter) and incorporated (on the Millipore filter). Note that the term "uptake" is not used to describe our results because acidification and filtration would not allow collection of intracellular dissolved pools of substrate not yet incorporated into macromolecules (Griffiths et al., 1974a) or the substrate loosely bound to cell membranes (Griffiths et al., 1974b). As such, the technique we used provides a conservative estimate of substrate uptake. 


\section{Data analysis}

All statistical analyses were performed using SYSTAT 5.2.1 for the Macintosh (SYSTAT, 1992). Multivariate analyses were done using fully factorial M(ANOVA) with total utilization rate $(v)$ as the dependent variable and incubation temperature $(T)$ and added substrate concentration $(A)$ as factors (Wilkinson, 1975; 1980). Non-linear surface fits were done using distance-weighted least-squares technique (McLain, 1974).

Non-linear curve fits to the hyperbolic model equation were done initially with the SIMPLEX estimation method (O'Neill, 1971; Griffiths, 1985). The model equation we used (see Appendix for derivation) assumes steady state at the cell surface and combines cell-specific diffusive flux $\left(J_{D}\right)$ and cellspecific uptake $\left(v_{S}\right)$ as a function of substrate concentration far from the cell surface $\left(C_{\infty}\right)$, cell radius $(r)$, and the diffusion coefficient $(D)$, to solve for cellspecific maximum uptake velocity $\left(V^{s}{ }_{\max }\right)$ and the half-saturation concentration $\left(K_{t}\right)$ :

$$
v^{S}=\frac{V_{\max }^{S}}{\left\{1+\left(\frac{2 * K_{t}}{\left.C_{\infty}-K_{t}-\frac{V^{S}{ }_{\max }}{4 \pi r D}+\sqrt{\left(\frac{V^{S}{ }_{\max }}{4 \pi r D}+K_{t}-C_{\infty}\right)^{2}+4 C_{\infty} K_{t}}\right)}\right)\right.}
$$

We computed $D$ for an amino acid with a "radius" of $10 \AA$ (Solomons, 1988) at the experimental temperature and station salinity for each treatment (Jumars et al., 1993), and used a cell radius equal to $0.5 \mu \mathrm{m}$ (which would 
equal the median cell radius if all cells had been spherical; see below). Since we did not have measures of UDOM concentration for every station and current measures of DOM do not really reflect bioavailable UDOM anyway (Karl, 1986), we substituted added substrate concentration, $A$, for $C_{\infty}$ instead of $S+A$, where $\mathrm{S}$ is the bioavailable concentration of amino acids. As such, our estimation of the half-saturation concentration equals the true half-saturation coefficient minus the bioavailable substrate concentration $\left(K_{t}-S\right)$ rather than a true $K_{t}$. Though the result of this assumption has no effect on the calculation of $V_{\max }$, it means we can only compare $K_{t}-S$ values within a single station and not across all stations. Since the primary goal of this study was to examine treatment (e.g. temperature) effects at individual stations, relative values are sufficient for our purposes here.

To examine diffusion limitation, we computed the dimensionless ratio, or mass Biot number, $P^{*}$ (Pasciak and Gavis, 1974) from the curve fit output:

$$
P^{*}=\frac{4 \pi r D K_{t}}{V^{S}{ }_{\max }}
$$

For each of the above calculations, we had to scale our measured community utilization rates by the number of bacteria per liter of sample to input $v s$. This assumes $100 \%$ active cells (see discussion) and may underestimate activity per cell if a smaller percentage is active. The complex equation above simplifies to the more common

$$
v=\frac{V_{\max } C_{\infty}}{K_{t}+C_{\infty}}
$$


and becomes independent of cell number when $V^{S}{ }_{\max } \ll 4 \pi \mathrm{r}_{\mathrm{o}} D K_{t}$ (or $P^{*}$ $>1$ ).

Standard errors were computed by estimating the Hessian (second derivative) matrix at the end of the SIMPLEX iteration (O'Neill, 1971; Griffiths, 1985). In most cases, the complexity and redundancy of Eq. (1) would not allow a positive definite solution of the matrix and, consequently, standard errors were not computable. In cases where $P^{*}>1$, therefore, we solved the simpler Eq. (3) to estimate standard error. In all such cases, estimates of $V_{\max }$ and $K_{t}$ were within less than $5 \%$ of values computed from Eq. (1).

Specific affinity $\left(a_{A}^{0}\right)$ is defined as the initial slope of the substrate $\left(C_{\infty}\right)$ versus cell specific utilization ( $v$ ) curve (Button, 1994). This parameter represents the instantaneous community response to an increase in substrate concentration. Again, since we cannot know $S$ with any certainty and were primarily interested in relative affinity as a function of temperature, we computed $a^{o} A$ as the slope of the added substrate $A$ versus utilization rate $v^{S}$ curve. If $S$ is large, this assumption may have caused us to underestimate $a^{0} A$. Also, since we did not know the percent active cells, our estimates of cell-specific affinities may be underestimates if a significant percentage of the directly counted bacteria are inactive. Such underestimation would not affect within-station comparisons, however.

We calculated $a_{A}^{0}$ by performing a sequence of linear regressions (Sokal and Rohlf, 1981) on the data from each experiment, starting with lowest concentrations and adding data points for higher added substrate concentrations until the slope started to decrease with saturation. At stations 
with noisy data, this process could be a bit subjective. Our strategy was to choose the maximum slope attained while also including the most data points and getting the best fit $\left(\mathrm{r}^{2}\right)$. Assuming a perfect hyperbolic model, one can also calculate $a_{A}^{0}=V_{\max } / K_{t}$. Because such a calculation compounds potentially high errors associated with $V_{\max }$ and $K_{t}$ estimations, we found that we obtained less error with the initial slope regressions and could thus detect differences due to temperature that we could not have detected statistically using $V_{\max }$ and $K_{t}$. In most cases, the two methods produced comparable values for $a_{A}^{o}$; only the magnitude of the estimated error differed.

Comparisons between computed values for $a^{0} A$ and $V_{\max }$ were done using planned pairwise T-tests (Sokal and Rohlf, 1981), comparing values from one temperature to values at the next warmest temperature.

\section{Results}

\section{Substrate availability}

Total dissolved free amino acids (DFAA) concentrations at the fluorescence-maximum ranged from 33 to $153 \mathrm{nM}$ (approximately 2.5 to $13 \mu \mathrm{g}$ $\mathrm{I}^{-1}$ ) in 1992 (Table III-1; 1993 samples fouled) and were fairly low compared to temperate oceans (15 - $80 \mu \mathrm{g} \mathrm{l}^{-1}$; as reviewed by Andrews and Williams, 1971). As is often reported for marine waters (e.g. Hubberten et al., 1994), the individual amino acids that dominated the composition were aspartic acid, serine, glycine, and methionine, with glutamic acid, tyrosine, alanine, histidine, and valine sometimes detected (data not shown). No significant correlation was observed between chlorophyll $a$ concentration and DFAA for 
the samples measured $(r=0.25, P>0.1)$. Unfortunately, organic carbon samples were contaminated and the data were not useful. Data collected by others aboard Polarstern overlap with our sampling depths and suggest that DOC and DON concentrations in some of our 1993 samples ranged from 88 to $194 \mu \mathrm{M}$ (or 1 to $2 \mathrm{mg} \mathrm{Cl}^{-1}$ ) and 5.1 to $6.4 \mu \mathrm{M}$ (or 61 to $77 \mu \mathrm{g} \mathrm{N}^{-1}$ ), respectively (A. Skoog, personal communication). Of note are the very high DOC:DON ratios $(14-34)$ of the DOM pool since they may indicate low lability of DOM in the polynya waters.

\section{Bacterial abundance}

Bacterial abundance data for all depths and stations sampled are available in published data reports (Wallace et al., 1995a; 1995b) accessible via the National Technical Information Service (U.S. Dept. of Commerce) or the NSDIC data base and are summarized for 1992 in the literature (Smith et al., 1995). In 1993, bacterial abundance within the euphotic zone was fairly low and averaged $1.66 \pm 0.13 \times 10^{8}$ liter $^{-1}$ ( $\pm 2 \times$ standard deviation, equals $95 \%$ confidence interval) with the maximal value at $7.92 \times 10^{8}$ liter $^{-1}$. Bacterial abundance correlated positively with chlorophyll concentration in $1992\left(\mathrm{r}^{2}=\right.$ $0.19, \mathrm{p}<0.01$; Smith et al., 1995) and also in $1993\left(\mathrm{r}^{2}=0.14, \mathrm{n}=315, \mathrm{p}<0.05\right.$, Fig. III-2), suggesting a coupling between bacteria and phytoplankton, but the regression coefficients $\left(\mathrm{r}^{2}=0.14-0.19\right)$ are small compared to most other regions ( $\mathrm{r}^{2}=0.75$, Cole et al., 1988; see also Ducklow and Carlson, 1992), indicating that a high percentage $(>80 \%)$ of the variability in bacterial abundance is not explained by chlorophyll at the sampled spatial and temporal scales. The slope of the logarithmic relationship is less than one (0.21 in 1992, Smith et al., 1995; 0.24 in 1993, Fig. III-2), and may also be 


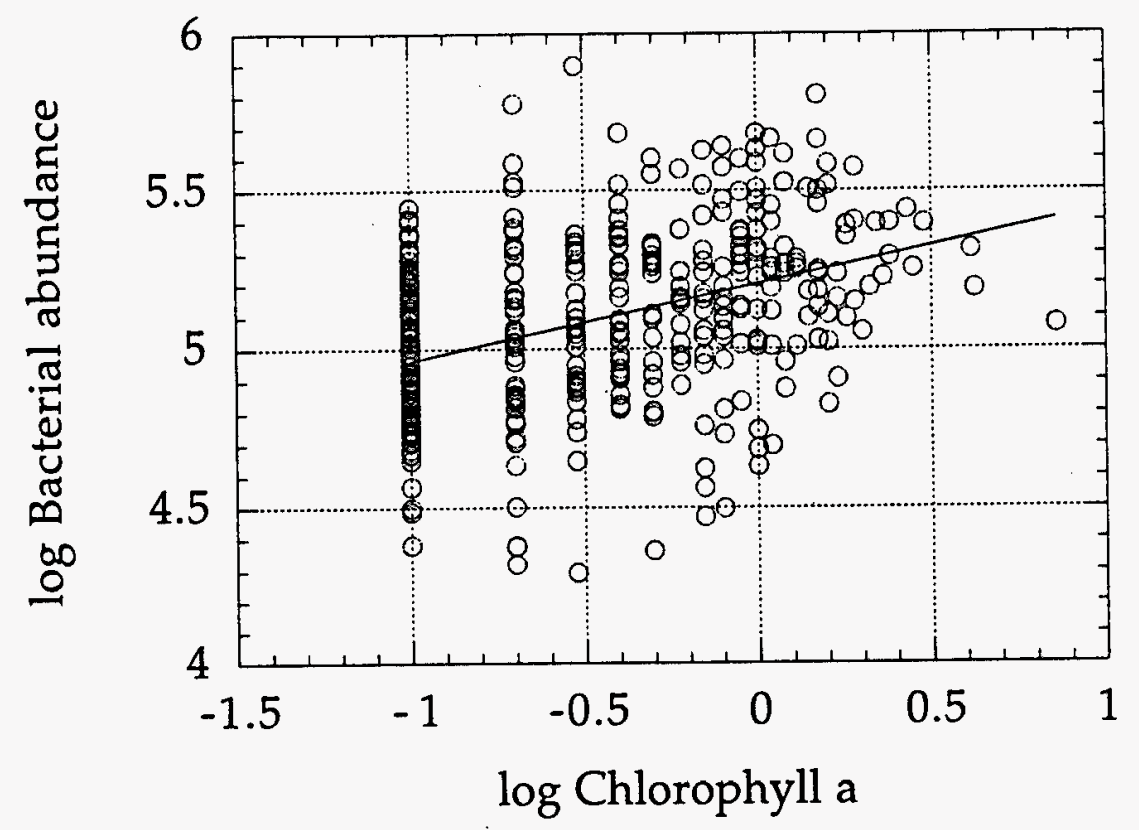

Figure III-2. Plot of $\log _{10}$ chlorophyll a concentration $\left(\mu \mathrm{g} \mathrm{kg}^{-1}\right)$ versus $\log _{10}$ bacterial abundance (cells ml${ }^{-1}$ ) for 1993 Polar Sea cruise. Regression line using standard linear regression has slope of $0.24, y$-intercept of $5.2, \mathrm{n}=315$, and $\mathbf{r}^{2}=0.14$. Geometric mean (Type II) regression gives a slope of 0.64 . 
shallower than in other regions (0.53; Cole et al., 1988), i.e., bacterial abundance does not increase to as great an extent at high chlorophyll concentrations, indicating either strong grazing pressure (Pace and Cole, 1994) or, alternatively, earlier saturation at the higher chlorophyll concentrations. The y-intercept values, perhaps indicative of overwintering stocks of bacteria present before phytoplankton bloom, are not significantly different from temperate ocean values (5.97; Cole et al., 1988) or each other, but they tended to be slightly higher in 1992 (6.84; Smith et al., 1995) and lower in 1993 (5.20, Fig. III-2). Note that all of these regressions were done using standard linear regression (Type I) for literature comparison. Geometric mean (Type II) regressions would be more accurate in terms of a predictive relationship, since there is error associated with the chlorophyll measurements. If geometric mean regressions are performed, the slope increases by dividing by the correlation coefficient, $\mathrm{r}$ (Sokal and Rohlf, 1981). For 1992, the slope more than doubles to 0.48 (Smith et al., 1995) and for 1993, to 0.64. When $r$ is large, the difference is minor (e.g., the slope for all oceans determined by Cole et al., 1988 , increases from 0.52 to 0.60 ), but when $r$ is small, as in the case of the polynya, the difference is striking. The Type II regression puts the polynya chlorophyll-bacteria relationship in a range more comparable to the rest of the ocean.

\section{Bacterial size}

Bacteria were unusually large and their populations dominated by rod-, crescent-, and spiral-shaped cells ( $72 \pm 6.5 \%$ of total), rather than the small cocci which typically dominate in the marine environment (Ferguson and Rublee, 1975). The average cell volume in the euphotic zone (computed from 
the median cell size measured for each of 20 samples) was $0.525 \pm 0.09 \mu \mathrm{m}^{3}$, with the maximum observed to be $0.835 \mu \mathrm{m}^{3}$. Notably, this large cell size corresponds well with a prey diameter that would produce the fewest encounters with non-swimming, 5- to $100-\mu \mathrm{m}$ diameter predators at in situ temperature and salinity (Fig. III-3).

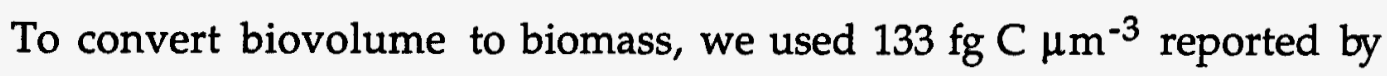
Simon and Azam (1989) for "average marine bacteria" at $0.4 \mu \mathrm{m}^{3}$ (their largest size category). This factor decreases non-linearly with increasing size, and may overestimate slightly $(<10 \%)$ the amount of carbon per volume in the large polynya bacteria.

\section{Potential growth rates}

Growth studies showed that all of the pelagic communities we measured in 1993 were dominated by psychrophiles when given enriched levels of organic nutrients. Maximum specific growth rates were as high as $1.96( \pm 0.14) \mathrm{d}^{-1}$ at in situ temperature and $2.85( \pm 0.10) \mathrm{d}^{-1}$ with warming (Fig. III-4). The optimal growth temperature ranged from $2^{\circ} \mathrm{C}$ to $10^{\circ} \mathrm{C}$ depending on the station. Station 93-42 even showed a bimodal psychrophilic response (Fig. III-4D). Experiments at the time-series station (Figs. III-4B and III-4C), one week apart from each other, produced similar growth curves. For comparison, the temperature response measured on a slurry of material from a short-term floating sediment trap deployed near the time-series station (Fig. III-1) showed a more psychrotolerant community with growth rates increasing to a maximum at $20^{\circ} \mathrm{C}$ (Fig. III-4F).

Nalidixic acid treatments with substrate showed no differences from those without enrichment, and did not exhibit the typically elongated cells we 


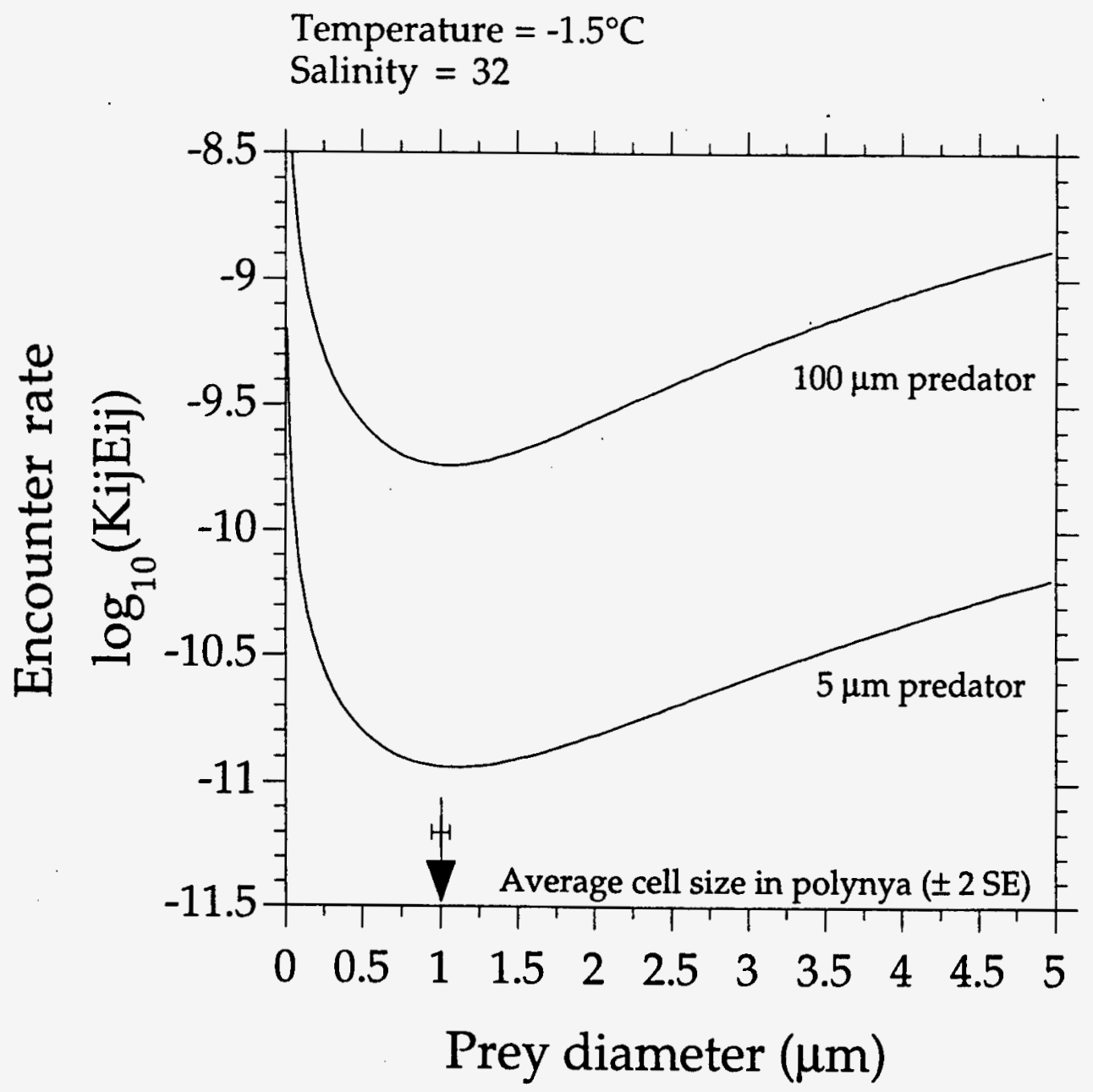

Figure III-3. Encounter rate (scaled to particle concentration; includes Brownian motion and turbulent shear coagulation mechanisms) as a function of prey diameter for two different predator sizes (see text or Jumars, 1993, for further explanation). Note that the shape and position of the curve is not very sensitive to predator size. To calculate actual encounter rate, multiply $\log _{10}\left(\mathrm{~K}_{\mathrm{ij}} \mathrm{E}_{\mathrm{ij}}\right)$ times the concentrations of predators and prey. Arrow indicates the average cell diameter ( \pm 2 standard errors) computed from the cell volumes of 20 samples from the time series location (see text). 
Figure III-4. Potential bacterial growth rates from samples supplemented with $0.01 \%$ yeast extract as a function of incubation temperature. Error bars indicate \pm 2 standard errors on estimate of growth rate. Seawater samples were from depths of maximum fluorescence: a) Sta. 93-1; b) 93-2; c) 93-37; d) 93-42; and e) 93-53 (see Table III-1). Growth rates were also measured on a particle slurry $(f)$ recovered from a short-term floating sediment trap deployed at the base of the euphotic zone $(\sim 50 \mathrm{~m})$ near the time-series station, 93-37. 

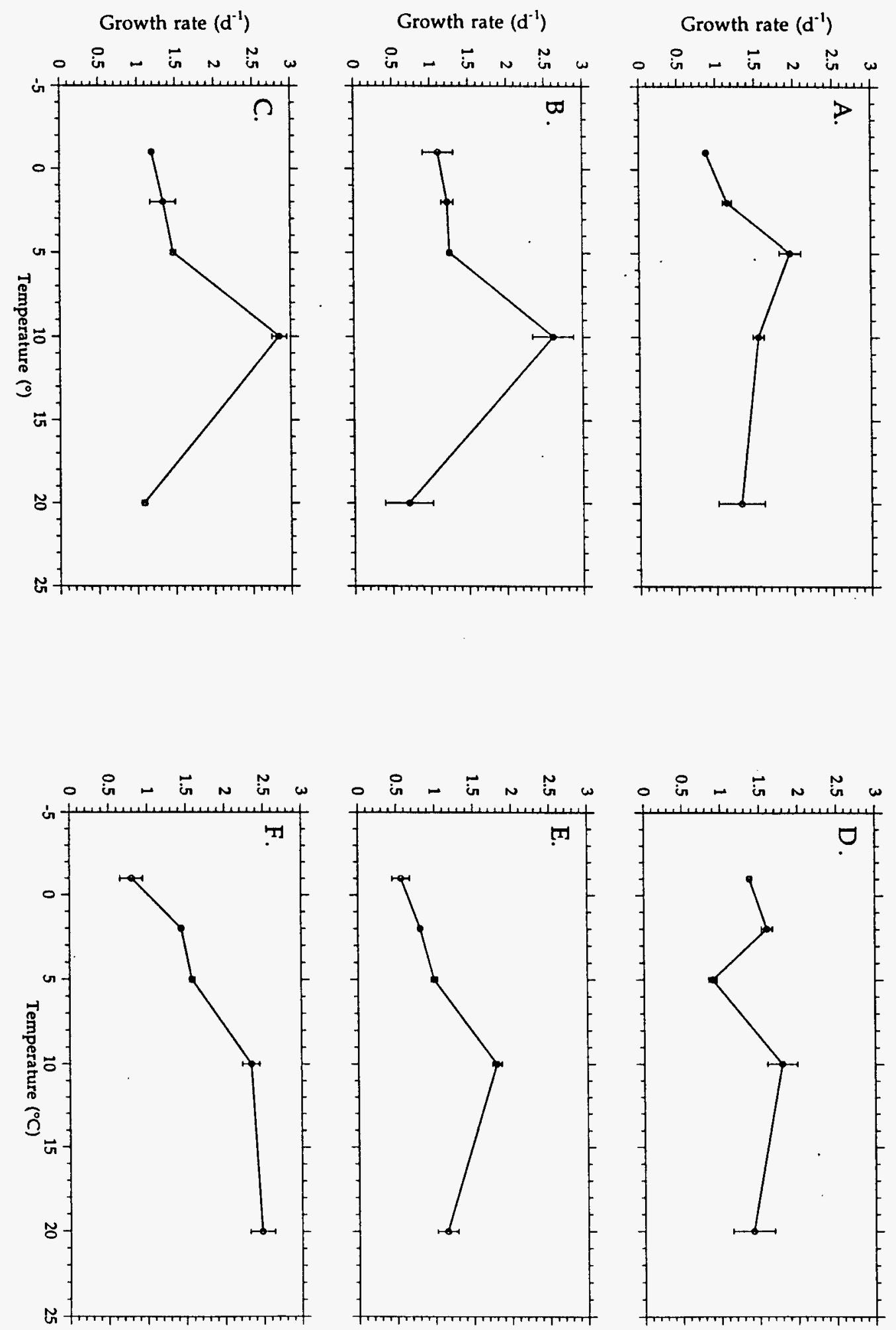
expected. Either polynya bacteria are resistant to Nalidixic acid or, more likely, incubation conditions were not optimal for detecting enlarged cells. The method has not been applied before to sub-zero waters to our knowledge; our experiments represent incomplete tests of the method as we did not verify optimal substrate type or concentration for this environment, but rather used the published method directly. In any case, the percentage of active cells was not accessible using this method.

\section{Utilization}

Utilization rates at near-surface fluorescence maximum depths showed linearity in the time-course experiments up to about $16 \mathrm{~h}$ (Fig. III-5) at subzero temperatures, even at the highest concentrations of added substrate. An end point of $12 \mathrm{~h}$ or less, therefore, was used for most subsequent end-point experiments. From the observed linearity, we expected that a 12-h incubation would be short enough to avoided changes in community structure during our experiment (see, for example, discussion in Jumars et al., 1993); in samples where we observed the relatively high specific growth rates described above, however, community shifts may have occurred. In the experiments with deep, warmer water samples (92-72, 92-78; see Table III-1) utilization was not detected.

Multivariate ANOVA was used to analyze the kinetics experiments for added substrate and temperature effects. In all nine experiments analyzed (Table III-2), added substrate concentration had a significant effect on utilization rates (with $\mathrm{P}_{\text {substrate }}<0.001$ at all but one station, where $\mathrm{P}_{\text {substrate }}$ was 0.022 ). Temperature had a significant effect at six of the nine stations, but had a combined effect with substrate concentration at only two of the nine 

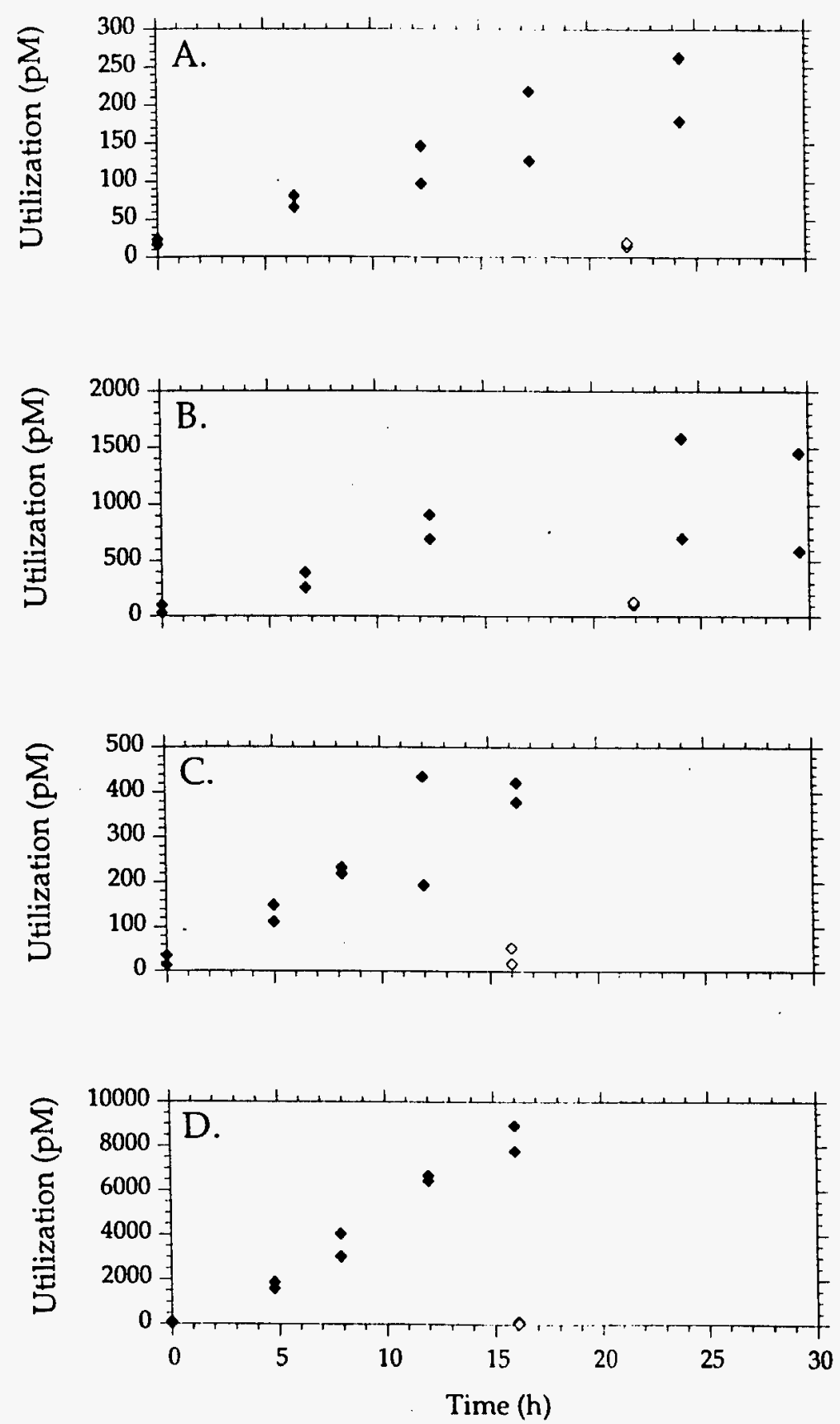

Figure III-5. Utilization of ${ }^{14} \mathrm{C}$-amino acid mixture (pmol $\mathrm{l}^{-1}$; solid diamonds) as function of time $(\mathrm{h})$ for seawater samples from station $92-25 \mathrm{~A}(\mathrm{a}$ and $\mathrm{b}$ ) and 92-43A ( $\mathrm{c}$ and $\mathrm{d}$ ) with $1 \mathrm{nM}$ ( $\mathrm{a}$ and $\mathrm{c}$ ) and $100 \mathrm{nM}$ ( $\mathrm{b}$ and d) substrate additions. Open diamonds are $2 \%$-formaldehyde killed controls. 
TABLE III-2: Results of M(ANOVA) test for effects on utilization rate.

\begin{tabular}{cccccc}
\hline Station & $\mathrm{n}$ & $\mathrm{R}^{2}$ & $\begin{array}{c}\mathrm{P}[\mathrm{A}] \\
\text { Added } \\
\text { Substrate }\end{array}$ & $\begin{array}{c}\mathrm{P}_{\mathrm{T}} \\
\text { Temperature }\end{array}$ & $\begin{array}{c}\mathrm{P} \\
{[\mathrm{A}] \times \mathrm{T}}\end{array}$ \\
\hline $92-25 \mathrm{~B}$ & 36 & 0.893 & $<0.001^{* *}$ & $0.003^{* *}$ & 0.157 \\
$92-43 \mathrm{~B}$ & 36 & 0.736 & $<0.001^{* *}$ & 0.390 & 0.620 \\
$92-49$ & 36 & 0.883 & $<0.001^{* *}$ & $0.002^{* *}$ & 0.195 \\
$92-56$ & 35 & 0.571 & $0.022^{* *}$ & 0.798 & 0.920 \\
$92-64$ & 36 & 0.912 & $<0.001^{* *}$ & $0.002^{* *}$ & $0.039^{*}$ \\
$93-30$ & 50 & 0.964 & $<0.001^{* *}$ & $<0.001^{* *}$ & $<0.001^{* *}$ \\
$93-43$ & 52 & 0.810 & $<0.001^{* *}$ & $<0.001^{* *}$ & 0.545 \\
$93-85$ & 100 & 0.818 & $<0.001^{* *}$ & $<0.001^{* *}$ & 0.289 \\
$93-2$ & 90 & 0.714 & $<0.001^{* *}$ & 0.651 & 0.930 \\
\hline
\end{tabular}

** Indicates $>99 \%$ confidence.

* Indicates $>95 \%$ confidence. 
stations. On average, added substrate concentration and temperature explained $81 \pm 12 \%$ of the variance seen in these experiments. A notable endmember is Station 92-56 which exhibited the lowest $r^{2}$ and $P_{\text {substrate }}$ values; this station also had the highest measured DFAA concentration.

\section{Kinetics}

Kinetic curves for the amino acid mixture appeared to follow a standard rectangular hyperbolic model for single substrate-enzyme interactions. Most of the stations showed rapid increase in utilization rates at low added concentrations and saturation at higher concentrations (Fig. III-6). With this result, we felt confident assuming the Michaelis-Menton uptake model and calculating $a^{o}{ }_{A}, V_{\max }$, and $K_{t}$ for each station.

Specific affinity. Values for $a^{0} A$ ranged from 1.23 to $12.8 \times 10^{-3} \mathrm{~h}^{-1}$ at sub-zero temperatures (Table III-3). Button (1994) reports specific affinity scaled to cell biomass per media volume (liter g-cells ${ }^{-1} \mathrm{~h}^{-1}$ ). To convert our data to these units, we used bacterial abundance from each station and assumed a cell mass of $116 \mathrm{fg}$ cell-1 $\left(0.525 \mu \mathrm{m}^{3} \times 133 \mathrm{fg} \mathrm{C}^{-1} \mathrm{~m}^{-3} \times 0.56 \mathrm{fg} C\right.$ fg dry weight $^{-1}$; Simon and Azam, 1989). Results ranged from 307 to 2340 liter gcells ${ }^{-1} \mathrm{~h}^{-1}$, or up to 4290 liter g-cells ${ }^{-1} \mathrm{~h}^{-1}$ when warmed to $2^{\circ} \mathrm{C}$. These values overlap with and even exceed the high end of values reported by Button (1994) for pure cultures of oligotrophs.

The response of $a_{A}^{o}$ to temperature was not uniform across all the stations in the polynya (Table III-3). Four stations confirmed the Pomeroy hypothesis of increased affinity for substrate at warmer temperatures. Three of the four experiments that showed this response were from the time-series 
Figure III-6: Distance-weighted least-squares surface fits (tension $=1$ ) of utilization rate (pmol $\mathrm{l}^{-1} \mathrm{~h}^{-1}$ ) as a function of added substrate concentration (nM) and temperature $\left({ }^{\circ} \mathrm{C}\right)$ for selected stations chosen to exemplify three behaviors described in text according to statistical information in Table III-2. a) substrate alone had a significant effect (Station 92-43B); b) substrate and temperature had significant effects (Station 92-25B); c) substrate, temperature, and an interaction between substrate and temperature, had significant effects (Station 92-64). 


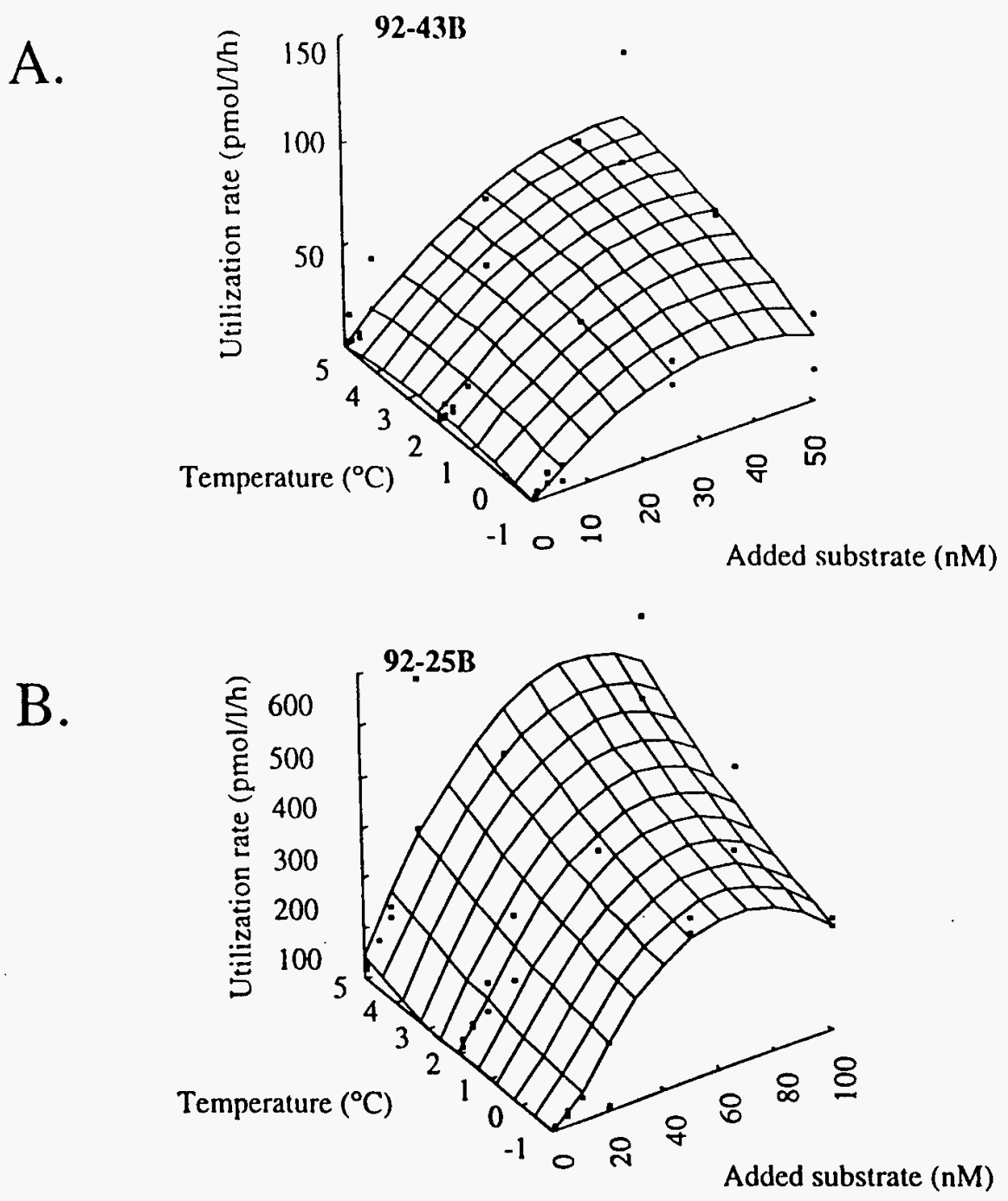

C.

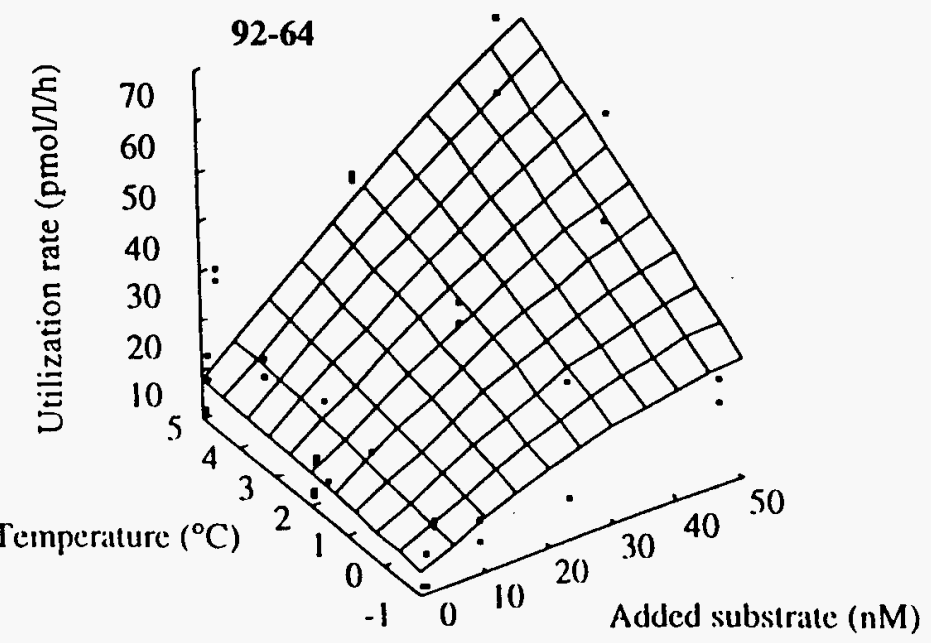


104

location in the central part of the polynya region. Two stations from the northeastern region showed strong psychrophilic behavior, with maximum affinities at either -1 or $2^{\circ} \mathrm{C}$. Three stations showed a bimodal response, with higher affinities at subzero temperatures decreasing at intermediate temperatures and then increasing again with warming. This result suggests either two distinct microbial communities or a shift in uptake mechanisms used by a single population.

Community $V_{\max }$ values ranged from 20 to $400 \mathrm{pmol}^{-1} \mathrm{~h}^{-1}$ (or 1.2 to $\left.22 \mathrm{ng} \mathrm{C}^{-1} \mathrm{hr}^{-1}\right)$ at sub-zero temperatures and were as high as $500 \mathrm{pM} \mathrm{h}^{-1}$ when incubated at $5^{\circ} \mathrm{C}$ (Table III-4; please note that the ordering of stations is different from in Table III-3). Community $V_{\max }$ did not correlate with bacterial abundance $(r=0.063, p>0.1)$, highlighting the weakness of the assumption that $100 \%$ of the directly counted bacteria were active. Thus, we do not present cell-specific $V^{S}{ }_{\max }$ here, but rather community $V_{\max }$ values. For comparison to other published data sets, however, if we do assume $100 \%$ active cells, $V_{\text {max }}^{S_{\text {max }}}$ ranged from 0.4 to $5.3 \mathrm{amol}^{\text {cell }} \mathrm{l}^{-1} \mathrm{~h}^{-1}$ (or 0.35 to $10 \mathrm{mg} \mathrm{g}$ cell $^{-1} \mathrm{~h}^{-1}$, if we assume $116 \mathrm{fg}^{\text {cell }}{ }^{-1}$; Simon and Azam, 1989).

Temperature effects on $V_{\max }$ were mixed (Table III-4). At four of the stations, including the two visits to the time-series station, there was a monotonic increase in $V_{\max }$ as incubation temperature warmed. At three of the stations there was a step up in $V_{\max }$ upon warming from sub-zero to 0 or $2^{\circ} \mathrm{C}$, but no significant increase after that. One station to the northeast showed extreme psychrophilic behavior with a maximum at $2^{\circ} \mathrm{C}$. One station (93-85) showed no difference in $V_{\max }$ due to temperature. 
$\mathbf{K}_{\mathbf{t}}-\mathbf{S}$, our estimation of the half-saturation concentration, ranged from 2.2 to $82.5 \mathrm{nM}$ (or 0.3 to $10 \mu \mathrm{g}$ liter $^{-1}$ ) at sub-zero temperatures and tended to have high associated standard errors (Table III-4). Computed values for an oligotrophic capacity index $\left(\log _{10}\left(a_{A}^{0} / K_{t}\right)\right.$; Button, 1994) were $8.58 \pm 0.71$ ( $\mathrm{n}=$ 9) at sub-zero temperatures, not significantly different from the value (9.0) described for organisms well adapted for survival in the pelagic ocean. This index only drops to $7.84 \pm 0.44$, if we try to compensate for our assumption that $K_{t} \approx K_{t}-S$ by letting $S=10 \mu \mathrm{g} \mathrm{liter}^{-1}$, an upper end of most of the amino acid concentrations measured, although this calculation does not account for any potential increase in $a^{0}$ had we incorporated $S$ in the estimation.

\section{Diffusion limitation}

For each experimental treatment we determined $P^{*}$, a dimensionless ratio that suggests diffusion limitation if it drops below about 2 (Pasciak and Gavis, 1974). If we assumed that $100 \%$ of the bacteria were active, $P^{*}$ values ranged from 6 to 127 at in situ temperatures (Table III-3), indicating no. diffusion limitation. If we calculate $P^{*}$ as a function of percent active cells, diffusion limitation at sub-zero temperature begins when the percent active drops below 15\% (Fig. III-7). Field measurements from Kiel Bight suggest anywhere from 2 to $60 \%$ of directly counted cells are actively taking up radiolabeled substrate (Meyer-Reil, 1978). Our cell morphology observations indicated that over $70 \%$ of the bacteria in the polynya were rod-, spiral-, or crescent-shaped. The dominance of small, apparently inactive (Morita, 1985), cocci expected in typical oligotrophic environments (Dawes, 1985; Deming and Baross, 1994) was not observed in the polynya and suggests that most of the cells were probably active. To completely address this question, a good 
106

TABLE III-3: Specific affinity as a function of incubation temperature (T).

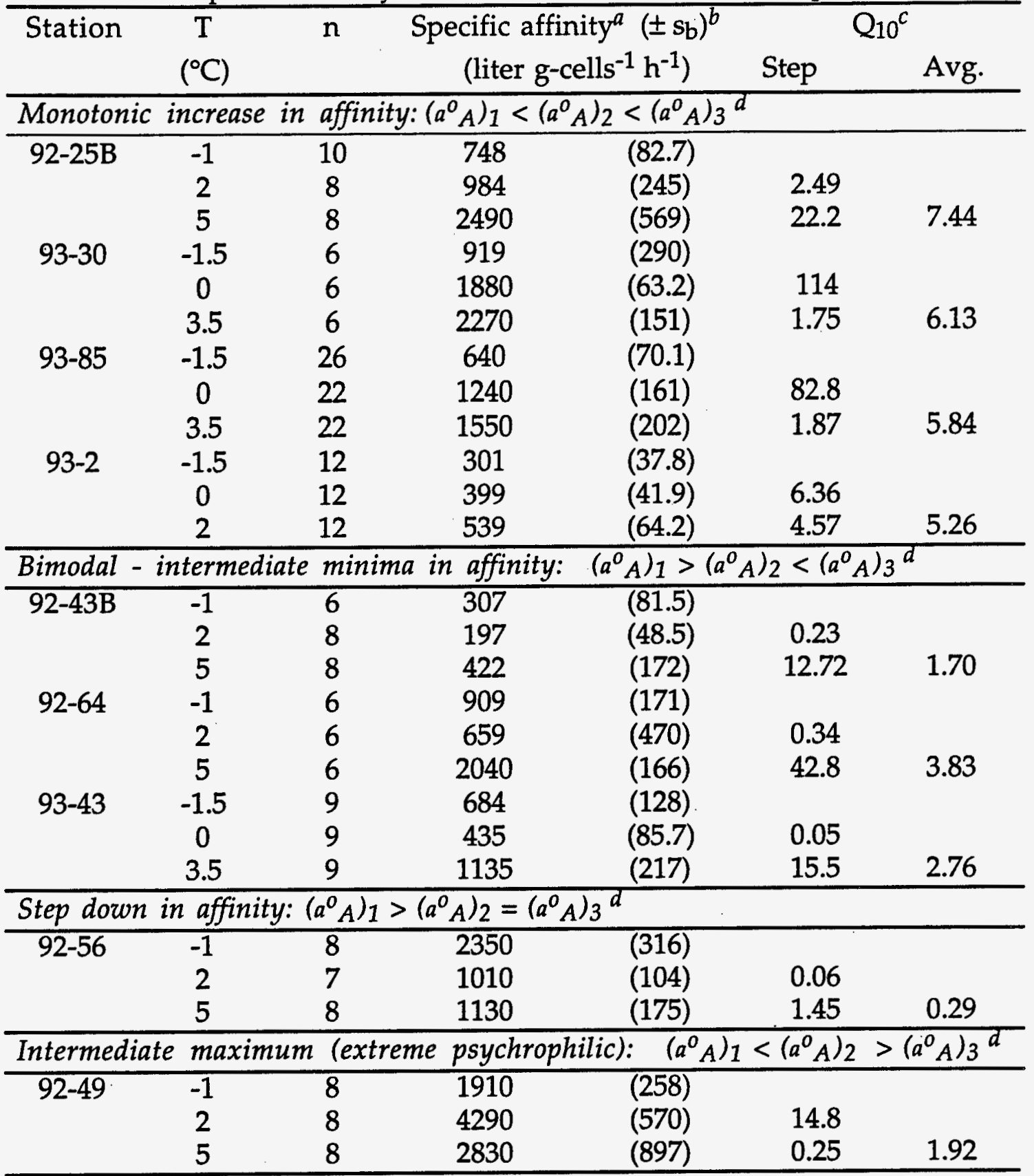

a Specific affinity (liter $\mathrm{g}$-cells $\mathrm{s}^{-1} \mathrm{~h}^{-1}$ ) unit conversion assumes $100 \%$ active cells, cell counts from Table III-1, $116 \mathrm{fg} \mathrm{cell}^{-1}$ (Simon and Azam, 1989), and $C_{\infty} \approx A$. (see text).

$b \quad \mathrm{sb}=1$ standard error of the specific affinity slope estimate (Sokal and Rohlf, 1981).

$c$ Step $Q_{10}=\left(\left(a_{A}^{o}\right)_{n+1} /\left(a_{A}^{o}\right)_{n}\right)^{\wedge}\left(10 /\left(T_{n+1}-T_{n}\right)\right)$. Avg. $\left.Q_{10}=\left(a_{A}^{o}\right)_{3} /\left(a_{A}\right)_{1}\right)^{\wedge}\left(10 /\left(T_{3}-T_{1}\right)\right.$.

$d$ Determined by one-tailed, planned pairwise $T$-tests for equality of samples with unequal variance, $\alpha \leq 0.05$, where $\left(\mathrm{a}^{\circ} \mathrm{A}\right)_{1}$ is $\mathrm{a}^{\circ} \mathrm{A}$ at the lowest, $\left(\mathrm{a}^{\circ} \mathrm{A}\right)_{2}$ the intermediate, and $\left(\mathrm{a}^{\circ} \mathrm{A}\right)_{3}$ the warmest temperature. 
TABLE III-4: Vmax and Kt-S as function of incubation temperature (T).

\begin{tabular}{|c|c|c|c|c|c|c|c|c|}
\hline Station & $\begin{array}{c}\mathrm{T} \\
\left({ }^{\circ} \mathrm{C}\right)\end{array}$ & \multicolumn{2}{|c|}{$\begin{array}{c}\mathrm{V}_{\max }(\mathrm{ASE})^{a} \\
\left(\mathrm{pM} \mathrm{h}^{-1}\right)\end{array}$} & \multicolumn{2}{|c|}{$\begin{array}{c}Q_{10}^{b} \\
\text { Step Avg. }\end{array}$} & \multicolumn{2}{|c|}{$\begin{array}{c}\mathrm{K}_{\mathrm{t}}-\mathrm{S}^{c}(\mathrm{ASE})^{a} \\
(\mathrm{nM})\end{array}$} & \multirow[t]{2}{*}{$\mathrm{p} * d$} \\
\hline \multicolumn{8}{|c|}{ Monotonic increase in $V_{\max }: V_{1}<V_{2}<V_{3} e$} & \\
\hline $92-25 B$ & $\begin{array}{c}-1 \\
2 \\
5\end{array}$ & $\begin{array}{l}379 \\
418 \\
511\end{array}$ & $\begin{array}{l}(109) \\
(75.5) \\
(117)\end{array}$ & $\begin{array}{l}1.39 \\
1.94\end{array}$ & 1.64 & $\begin{array}{l}39.9 \\
25.3 \\
16.4\end{array}$ & $\begin{array}{l}(26.6) \\
(12.5) \\
(12.1)\end{array}$ & $\begin{array}{l}17.7 \\
11.4 \\
6.76\end{array}$ \\
\hline $92-43 B$ & $\begin{array}{c}-1 \\
2 \\
5\end{array}$ & $\begin{array}{l}42.1 \\
86.1 \\
175\end{array}$ & $\begin{array}{l}(9.2) \\
(30.3) \\
(337)^{f}\end{array}$ & $\begin{array}{l}10.9 \\
10.7\end{array}$ & 10.8 & $\begin{array}{l}10.1 \\
15.2 \\
81.2\end{array}$ & $\begin{array}{l}(6.55) \\
(14.1) \\
(231)\end{array}$ & $\begin{array}{l}54.0 \\
44.6 \\
127\end{array}$ \\
\hline $92-49$ & $\begin{array}{c}-1 \\
2 \\
5\end{array}$ & $\begin{array}{l}128 \\
240 \\
333\end{array}$ & $\begin{array}{l}(19.6) \\
(28.0) \\
(58.4)\end{array}$ & $\begin{array}{l}8.32 \\
2.95\end{array}$ & 4.95 & $\begin{array}{l}6.93 \\
2.92 \\
9.42\end{array}$ & $\begin{array}{l}(3.80) \\
(1.62) \\
(5.71)\end{array}$ & $\begin{array}{l}7.41 \\
1.88 \\
4.87\end{array}$ \\
\hline $93-2$ & $\begin{array}{c}-1.5 \\
0 \\
2\end{array}$ & $\begin{array}{l}128 \\
199 \\
318\end{array}$ & $\begin{array}{l}(58.1) \\
(131) \\
(382) g\end{array}$ & $\begin{array}{l}18.9 \\
10.5\end{array}$ & 13.5 & $\begin{array}{l}52.5 \\
62.2 \\
120\end{array}$ & $\begin{array}{l}(40.4) \\
(67.6) \\
(229)\end{array}$ & $\begin{array}{l}59.8 \\
48.5 \\
63.5\end{array}$ \\
\hline \multicolumn{9}{|c|}{ Step up in $V_{\max }: V_{1}<V_{2}=V_{3} e$} \\
\hline $92-64$ & $\begin{array}{c}-1 \\
2 \\
5\end{array}$ & $\begin{array}{l}21.4 \\
54.4 \\
51.3\end{array}$ & $\begin{array}{l}(3.90) \\
(30.0) \\
(4.71)\end{array}$ & $\begin{array}{l}22.4 \\
0.82\end{array}$ & 4.29 & $\begin{array}{l}2.20 \\
12.8 \\
2.71\end{array}$ & $\begin{array}{l}(1.59) \\
(23.7) \\
(1.07)\end{array}$ & $\begin{array}{l}14.5 \\
36.7 \\
9.34\end{array}$ \\
\hline $93-30$ & $\begin{array}{c}-1.5 \\
0 \\
3.5\end{array}$ & $\begin{array}{l}52.3 \\
101 \\
119\end{array}$ & $\begin{array}{l}(8.04) \\
(28.8) \\
(12.7)\end{array}$ & $\begin{array}{l}81.9 \\
1.58\end{array}$ & 5.16 & $\begin{array}{l}24.0 \\
74.8 \\
32.1\end{array}$ & $\begin{array}{l}(10.2) \\
(42.0) \\
(8.43)\end{array}$ & $\begin{array}{l}17.5 \\
29.6 \\
12.3\end{array}$ \\
\hline $93-43$ & $\begin{array}{c}-1.5 \\
0 \\
3.5\end{array}$ & $\begin{array}{l}29.1 \\
39.2 \\
40.3\end{array}$ & $\begin{array}{l}(5.10) \\
(7.02) \\
(4.88)\end{array}$ & $\begin{array}{l}7.36 \\
1.08\end{array}$ & 1.92 & $\begin{array}{l}23.1 \\
30.4 \\
9.11\end{array}$ & $\begin{array}{l}(11.4) \\
(13.7) \\
(4.01)\end{array}$ & $\begin{array}{l}30.1 \\
31.2 \\
10.4\end{array}$ \\
\hline \multicolumn{9}{|c|}{ No change in $V_{\max }: V_{1}=V_{2}=V_{3} e$} \\
\hline 93-85 & $\begin{array}{c}-1.5 \\
0 \\
3.5\end{array}$ & $\begin{array}{l}159 \\
149 \\
150\end{array}$ & $\begin{array}{l}(41.3) \\
(27.6) \\
(22.7)\end{array}$ & $\begin{array}{l}0.67 \\
1.02\end{array}$ & 0.9 & $\begin{array}{l}82.5 \\
52.4 \\
33.7\end{array}$ & $\begin{array}{l}(40.5) \\
(21.6) \\
(13.2)\end{array}$ & $\begin{array}{l}20.1 \\
14.3 \\
10.4\end{array}$ \\
\hline \multicolumn{9}{|c|}{ Intermediate maximum $V_{\max }\left(\right.$ Extreme psychrophilic): $V_{1}<V_{2}>V_{3} e$} \\
\hline $92-56$ & $\begin{array}{c}-1 \\
2 \\
5\end{array}$ & $\begin{array}{l}78.3 \\
267 \\
33.8\end{array}$ & $\begin{array}{l}(18.3) \\
(100) \\
(8.15)\end{array}$ & $\begin{array}{l}59.4 \\
0.001\end{array}$ & 0.25 & $\begin{array}{l}5.70 \\
22.4 \\
2.90\end{array}$ & $\begin{array}{l}(4.76) \\
(22.3) \\
(2.36)\end{array}$ & $\begin{array}{l}6.03 \\
7.97 \\
8.76\end{array}$ \\
\hline
\end{tabular}

\footnotetext{
a Associated Standard Error (SYSTAT, 1992).

$b$ Step $Q_{10}=\left(V_{n+1} / V_{n}\right)^{\wedge}\left(10 /\left(T_{n+1}-T_{n}\right)\right)$. Average (Avg.) $\left.Q_{10}=V_{3} / V_{1}\right)^{\wedge}\left(10 /\left(T_{3}-T_{1}\right)\right.$.

$c$ Curve fit made to added concentration [A], not total $[S+A]$, half-saturation value is $K_{t}-S$.

$d \mathrm{P}^{*}$ is the ratio of diffusive flux to the cell and cell-specific maximum uptake rate (see text); Assume $100 \%$ active cells. $P^{*} \leq 2$ indicates diffusion-limitation (Pasciak and Gavis, 1974).

$e$ Determined by one-tailed, planned pairwise T-tests for equality of samples (variances assumed unequal), where $V_{1}$ is $V_{\max }$ of lowest, $V_{2}$, intermediate, and $V_{3}$, warmest temp.

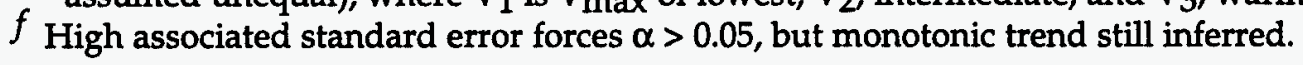




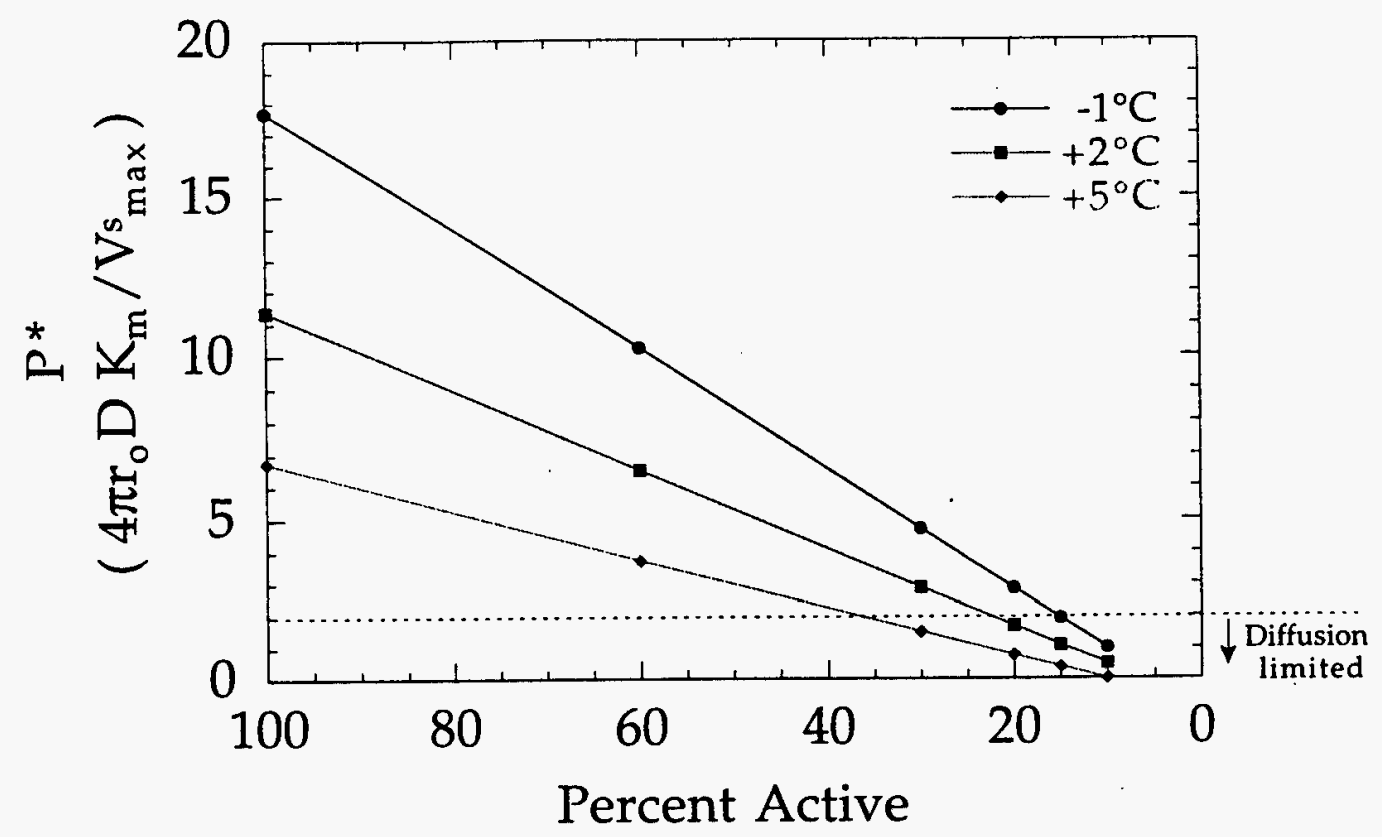

Figure III-7. Dimensionless ratio $\left(P^{*}\right)$ of cell-specific diffusive flux to cellspecific maximum utilization rate (as determined from measured values for community $V_{\max }$ and direct counts of bacterial abundance) as a function of the percentage of active cells assumed (data from Station 25B). Results generated by repeated non-linear curve fits to same data set using different concentrations of active cells. Diffusion limitation (as defined by $\mathrm{P}^{*}<2$; dotted line) at sub-zero temperatures begins when active cells drop below about $15 \%$ of direct counts. 
measure of the percent active cells in a high-latitude environment is required. Also, if the dominant food source for microbes were larger molecules than we modeled (see below), diffusion rates could be slower and cells diffusion-limited in situ.

\section{Discussion}

In polar oceans, heterotrophic pelagic bacteria must cope with a highly seasonal fresh food supply but permanently cold temperatures. The most competitive organism in such an environment would be expected to have constitutive, high-affinity transport systems but metabolic rates sensitive to available substrate concentrations. Combining the pure culture data of Wiebe et al. $(1992,1993)$ with the kinetic model of Button (1985; 1991; 1994), we expected to find a strong temperature sensitivity in substrate affinity (or in growth efficiencies; Chapter 4), with affinity increasing with warming, as long as the cells were not diffusion-limited. We also expected $V_{\max }$, which reflects the density of membrane transporters as well as the most rate-limiting step in cytoplasmic enzymatic processing, to change little with temperature, with $\mathrm{Q}_{10}$ (reaction rate quotient for $10^{\circ} \mathrm{C}: \log \mathrm{Q}_{10}=\log \left\{\mathrm{V}_{2} / \mathrm{V}_{1}\right\}\left\{10 / \mathrm{T}_{2}-\mathrm{T}_{1}\right\}$; Thimann, 1963) ranging between the diffusional value of 1.4 (Jumars et al., 1993) and the physiological value of about 2 .

Temperature effects on $a_{A}^{o}$ and $V_{\max }$ followed our predictions at only some of the stations we studied. The time-series station exhibited consistently increasing values with warming for both $V_{\max }$ and $a^{0} A$ and a population that showed optimum potential growth at $10^{\circ} \mathrm{C}$. This station is in the central, mostly open-water region and may have received greater cumulative radiative flux by the time of our sampling (Minnett, 1995) 
compared to other stations. Strong psychrophilic behavior was observed at other stations, particularly those in the far northeast corner of the study region influenced more by Arctic Ocean source waters (Wallace et al., 1995c). Although the variability we observed likely reflects naturally occurring variability in the system, some of the variability in the data may have been caused by unknown differential presence of grazers, since we did not prefilter the samples. We opted not to prefilter, however, because of the potentially dramatic effect filtration can have on the DOM available to bacteria (e.g. Carlson et al., 1996).

In our experiments, we looked only at microbial utilization of low molecular weight, $\mathrm{N}$-rich organic matter. Implicit in these experiments, therefore, is the assumption that microbes will use this type of substrate preferentially over other, less labile or higher molecular weight organic material. Since bacteria are known to be capable of diauxic growth (as originally proposed by Monod, 1942), they can be expected to regulate uptake processes so as to utilize the better substrate first; i.e., as the NEW Polynya bacteria encounter amino acids, they will prefer them to other less labile material. By using a mixture of amino acids that mimics the composition of phytoplankton or zooplankton exudate, we expected our results to reflect "reality" better than if we had used a single substrate. Nevertheless, if the bacteria in the polynya are not regularly exposed to such a labile food supply, we measured their behavioral response to high quality food pulses and not some "average" condition. Since our goal was a comparative one (temperature and substrate concentration effects on utilization), we can still draw conclusions about the sensitivity of this microbial response. 
Generalizing the results to the overall carbon cycle of the polynya should await a better understanding of controls on DOM production in the region.

Specific affinities were high compared to those reported by Button (1994) and seem to indicate that the bacteria in the polynya were ready to take up whatever labile substrate diffused towards them. This responsiveness is also confirmed by high oligotrophic capacities. Polynya bacteria certainly appear ready, at least at some stations, to respond quickly to increases in substrate availability.

Polynya $V_{\max }$ values (ranging from 21 to $510 \mathrm{pmol} \mathrm{l}^{-1} \mathrm{~h}^{-1}$ ) compared favorably to some of those measured by other investigators in coastal Arctic waters (1.4 - $770 \mathrm{pmol} \mathrm{l}^{-1} \mathrm{~h}^{-1}$ for glutamic acid in Alaskan waters; Griffiths et al., 1978). Our rates also compare well with those reported by Baross and Morita (1978) for glutamic acid utilization in Arctic (6.8 - $1160 \mathrm{pmol} \mathrm{l}^{-1} \mathrm{~h}^{-1}$; Morita et al., 1977) and Antarctic seawater (7.5 - $591 \mathrm{pmol} \mathrm{l}^{-1} \mathrm{~h}^{-1}$; Morita, 1975). Pomeroy et al. (1990) did not calculate $V_{\max }$, but they added sub-saturating (at least according to those we observed in this study) concentrations of substrate (34 $\mathrm{nM})$ to an Arctic Ocean water sample from $30 \mathrm{~m}$ depth and measured utilization of ${ }^{14} \mathrm{C}$-glutamic acid over an order of magnitude greater (2670 pmol $\mathrm{l}^{-1} \mathrm{hr}^{-1}$ ) than most of our maximum rates.

The result that utilization did not correlate with bacterial abundance has been reported before for polar (Antarctic) environments (Karl et al., 1991; Hanson et al., 1983) and may indicate either a high degree of metabolic diversity of cells related to phenotypic or genotypic community structure or that a large and variable percentage of the cells were inactive. If grazing was important in the polynya (see Chapter 4 for data suggesting that it was), the 
112

half-life of an inactive cell should have been fairly short, supporting the former rather than the latter hypothesis.

The larger than normal cell size is indeed consistent with significant grazing pressure since the cell diameter that provides the minimum encounter rate with non-swimming prey at these temperature and salinities is around $1 \mu \mathrm{m}$ (see Fig III-3), which gives a spherical volume of about 0.524 $\mu \mathrm{m}^{3}$, precisely the average cell size measured in the polynya $\left(0.525 \mu \mathrm{m}^{3}\right)$. This correspondence may be merely coincidence, especially since the coagulation model we used does not account for non-spherical or motile "particles." Incorporating grazer morphology and behavior, and also the efficiency with which encounter translates into ingestion, can increase or decrease the optimum prey size for minimal encounter (Shimeta, 1993; Shimeta et al., 1995). Until we know more about the bacterivores from the polynya, however, accounting for such complexity is not possible in our analysis. The most we can infer is that the result from the simple coagulation model is consistent with interpretations of the chlorophyll $a$ versus bacterial abundance comparison (Fig. III-2 and Smith et al., 1995): both approaches support the hypothesis that the bacteria are under significant grazing pressure. (As discussed in Chapter 4, results of directly measuring bacterivory also agree with this conclusion.)

On the basis of previous research, we expected to measure a single response to temperature by the polynya bacteria. The null hypothesis was that specific affinity would increase with warming; we expected to collect data that would either support this hypothesis or disprove it. In fact we have some stations that support the hypothesis and others that do not. It is clear that the polynya region supports a complex microbial community with a 
range of responses to temperature. Since the collection of our data, Pomeroy and Wiebe have experimented with pure cultures of psychrophiles and reached much the same conclusion (Pomeroy et al., 1995). Their research with pure cultures confirms that we can no longer simplify the temperature and substrate responses of psychrophiles with a single type of behavior. Prediction now becomes more difficult, unless we can obtain a better idea of community structure at any given point in time and space and what determines it.

The larger question is what will happen over longer-term warming of Arctic water masses? Will a permanent environmental temperature shift cause a behavioral shift by the existing community, as we observed in our short-term experiments, or will a change in temperature favor one part of the community over the other and generate a shift in community structure? We might have predicted the former had we only observed one behavioral response to warming. However, our detection of several different behaviors favors the latter scenario, in which case a closer examination phenotypic and genotypic microbial diversity (and related controls) is warranted.

\section{Conclusions}

Pelagic bacteria in the NEW Polynya exhibited very high affinity for mixed amino acids and appeared to be well-adapted to living at low temperatures. In the NEW Polynya region, phytoplankton productivity and biomass has been described as a mosaic in terms of spatial and temporal heterogeneity (Smith, 1995). In the case of the bacterioplankton, we observed a similar heterogeneity with respect to temperature responses, reflecting perhaps large variations in community structure linked to primary 
productivity, hydrography, or both. Temperature limitation seems to occur only sometimes, and then in the main polynya regions where residence times of water masses may be longer-(Top, 1994), and surface waters have the potential to warm more later in the season. More psychrophilic behavior seems to occur in the northeast quadrant, perhaps reflecting more influence from the Arctic outflow, including increased nutrient flux, primary production, and herbivory. For the remineralization role of pelagic bacteria to be modeled accurately, and insightful prediction of carbon fluxes in the Arctic reached, a better understanding of microbial community structure and what controls it must be achieved. Our work suggests that more knowledge of the behavior of psychrophilic bacteria is warranted and that grazing pressure on bacteria cannot be ignored in either ecosystem or carbon-flux models. 


\section{Pelagic microbial efficiency in the Northeast Water Polynya:}

IMPLICATIONS FOR INORGANIC CARBON CYCLING

AND THE BIOLOGICAL PUMP.

\section{Abstract}

The microbial fate of carbon in the Northeast Water (NEW) Polynya $\left(77-81^{\circ} \mathrm{N}, 6-17^{\circ} \mathrm{W}\right)$ during summertime 1992 and 1993 was investigated using a mass balance approach involving a diverse suite of measurements. We measured microbial utilization of ${ }^{14} \mathrm{C}$-labeled organic substrates and followed carbon through anabolic (incorporation) and catabolic (respiration) pathways. Incorporation efficiencies (incorporation relative to total utilization) were obtained for mixed amino acids, leucine, glutamic acid, and glucose. Unusually high efficiencies were observed for mixed amino acids ( $86 \pm 5 \%$ ) and leucine (>95\%), suggesting that high-latitude microbes may tend to reserve rather than quickly metabolize nitrogen-rich or labile food supplies. Bacterial nucleic acid and protein production were measured using ${ }^{3} \mathrm{H}$ thymidine and ${ }^{14} \mathrm{C}$-leucine incorporation. Unbalanced growth with preference for biomass building over cell division was observed, depending on our assumption of genome size. This result corresponds with the observations of unusually large cells and low to moderate bacterial abundance in these waters. Bacterivory, measured by the dilution technique, was patchy and ranged from 25 to $>100 \%$ of bacterial growth when detected by this method, suggesting that these highly efficient bacteria provide a link to higher trophic levels. Bacterial specific growth rates $\left(0.74-3.0 \mathrm{~d}^{-1}\right)$, at in situ 
temperatures $\left(-1.5^{\circ} \mathrm{C}\right)$ obtained using the dilution technique, also agreed with potential bacterial growth rates measured using 8-d enrichment experiments. Our results suggest some survival strategies adopted by these high-latitude microbes and allow us to estimate the role of pelagic microbes in the overall carbon flux of the NEW polynya region; they concur with undersaturated inorganic carbon concentrations observed in the polynya surface waters and suggest a highly efficient biological pump in the NEW Polynya surface waters.

\section{Introduction}

One of the most resilient paradigms in oceanography is the idea of the biological pump, the mechanism by which organisms facilitate carbon removal from the atmosphere to the deep ocean. The efficiency of the biological pump at high latitudes influences atmospheric carbon concentrations over glacial-interglacial time periods (Knox and McElroy, 1984) and is of vital importance in understanding the linkages between ocean productivity, ocean chemistry, and atmospheric carbon dioxide (Berger et al., 1989). Coastal oceans are both more productive and better at sequestering carbon than open-ocean ecosystems, perhaps due to their more episodic nature (Berger et al., 1989) and thus more efficient biological pump. Episodicity is especially critical in high-latitude ecosystems where spatial and temporal heterogeneity are the rule (e.g., Smith et al., 1995). The multidisciplinary NEW Polynya project (NEWater Investigators, 1993; Overland, 1995; Hirche and Deming, in press) provided a unique opportunity for us to investigate the efficiency of the biological pump in a region which combines both coastal and high-latitude characteristics. 
The NEW Polynya is a seasonally recurrent opening in the permanent ice of the coastal Arctic (Fig. IV-1). It typically starts to open in May, and closes by late September to mid-October (Böhm et al., 1995). During the 24-h sunlight of the boreal summer, reduced snow and ice cover allow deeper light penetration which enables first ice algae and then phytoplankton to bloom. Polynyas are being considered as model environments for seasonally icecovered Arctic continental shelves. The proposed biological pump for the NEW Polynya region (Deming et al., 1995) shows how it functions as a carbon shunt locally to the shelf benthos and regionally to the slope and Greenland Sea basin. The timing of biological activity with respect to sea-ice coverage is quite important, however, in controlling the magnitude and direction of carbon flux in seasonally ice-covered oceans like the polynya (Yager et al., 1995).

In coastal Arctic regions, where carbon export may not follow typical steady-state assumptions, the efficiency of the biological pump may depend on the role of the microbial loop (Chapter 1); i.e., whether microbes operate as a carbon link between dissolved organic matter (DOM) and higher trophic levels (e.g., Azam et al., 1983) or simply respire the available organic carbon, returning primary production to the inorganic pool, and allowing little carbon transfer to higher trophic levels (e.g., Ducklow et al., 1986).

The behavior of the microbial loop in high-latitude regions is of particular interest (Karl, 1993; Pomeroy and Wiebe, 1993) because sub-zero in situ temperatures seem to constrain some, though not all (Chapter 3), marine bacteria to utilizing organic matter only when it is available in high concentrations (Pomeroy and Deibel, 1986; Pomeroy et al., 1990; 1991; Wiebe et al., 1992; 1993). Organic matter concentrations in high-latitude seas that 


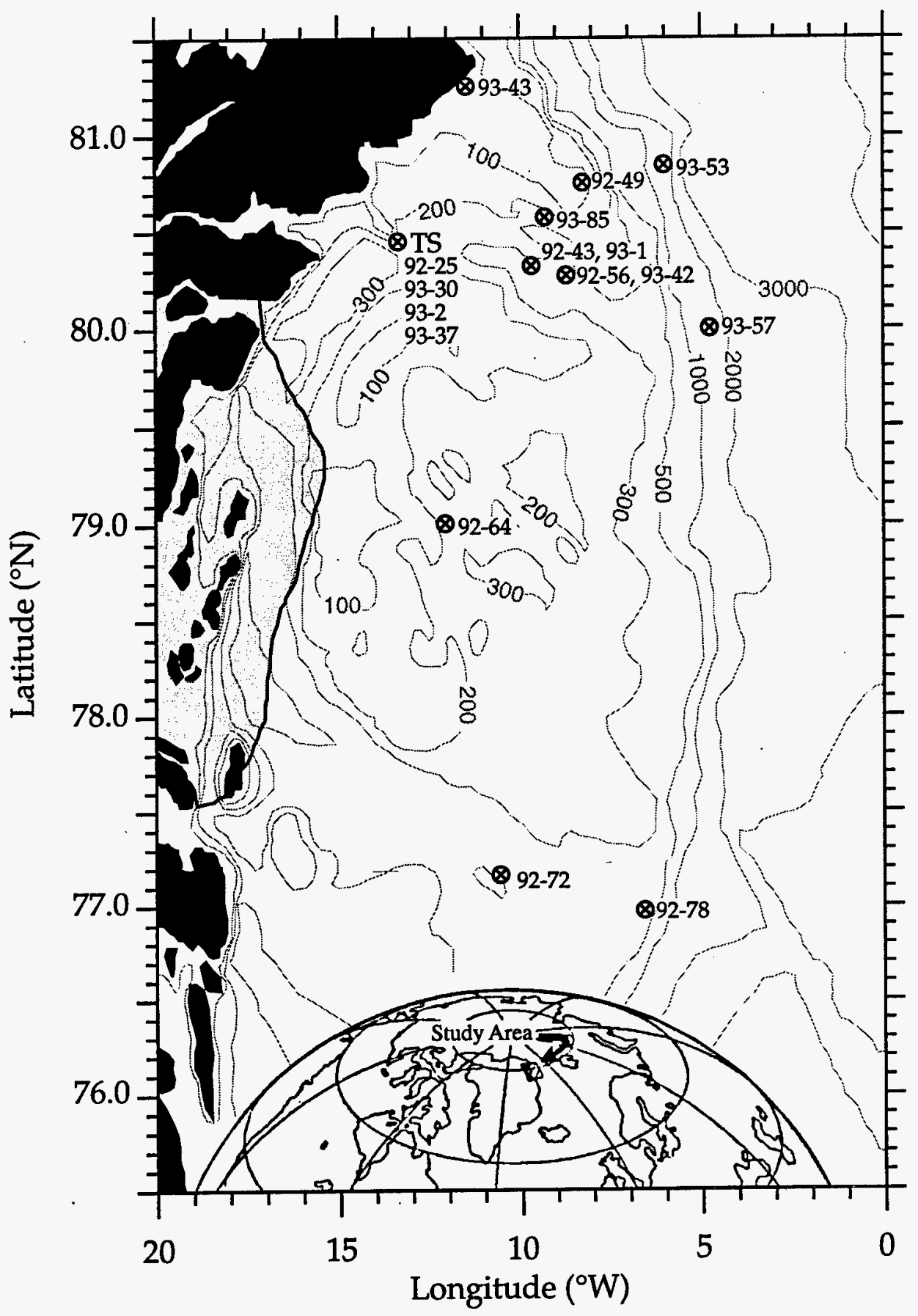

Figure IV-1. Map of NEW Polynya with microbiological stations. Depth contours in meters. 
remain below this threshold presumably escape microbial remineralization and contribute to a more efficient biological pump. An alternative mechanism for minimizing the respiration of carbon is for some highlatitude bacteria to respond to low concentrations of organic matter, but utilize it very efficiently, acting as a biomass shunt or "link" to higher trophic levels. By storing carbon in the organic form during critical times of the annual cycle, high-latitude seas may enhance their function as atmospheric carbon sinks (Chapters 1 and 2). Whether by one or both of these mechanisms, minimized summertime respiration contributes to the seasonal model for air-sea gas exchange hypothesized for the NEW Polynya region (Yager et al., 1995). Understanding the sensitivity of this storage behavior to predicted high-latitude warming (Hansen et al., 1984) may be critical to predicting potential biogenic feedbacks to anthropogenic perturbation.

The first hypothesis described above, that high-latitude bacteria are unable to access low concentrations of organic matter at sub-zero temperatures, was supported by only some microbial community experiments in the NEW Polynya (Chapter 3). Other stations, particularly those that may be more strongly influenced by recent Arctic Ocean outflow (e.g., 92-49 and 92-56), show no such limitation (Chapter 3; Table III-3), yet still exhibit significant biologically mediated inorganic carbon deficits during the summer (Chapter 2; Table II-1). This chapter will address the latter part of the second hypothesis described above, that psychrophilic bacteria contribute to the biological pump in high-latitude seas by efficiently incorporating or storing DOM as biomass and acting as a link to higher trophic levels.

The efficiency with which bacteria and other microorganisms utilize their food supply depends on several factors. Low carbon to nitrogen $(C / N)$ 
ratios of utilizable substrates have been shown to increase gross growth efficiency of some bacteria (Goldman et al., 1987; Linley and Newell, 1984). Limited nitrogen supplies, however, can also contribute to increased storage and cell size in some bacteria (Kragelund and Nybroe, 1994; Ramsay et al., 1992), which may resemble high growth efficiency depending on the measurement method used. Lower temperatures may also contribute to higher efficiency by reducing respiratory rates relative to growth (Bjørnsen, 1986; Christian and Wiebe, 1974) or inducing higher enzyme production (Reichardt, 1991) in cold-adapted microbes. We found deep-sea benthic microbial populations at high latitudes to show increased incorporation efficiency (Deming and Yager, 1992) at cold (sub-zero) temperatures relative to temperate deep-sea counterparts $\left(\right.$ at $\left.2^{\circ} \mathrm{C}\right)$, when identical measurement methods were used. The apparent trend of decreased respiration at cold temperatures motivated us to investigate the respiration-temperature relationship more explicitly in the permanently cold $\left(\leq 5^{\circ} \mathrm{C}\right)$ pelagic zone of the NEW Polynya.

\section{Methods}

During the 1992 and 1993 cruises of the USCGC Polar Sea (July 15 August 15, 1992; July 18 - August 18, 1993) and FV Polarstern (ARK IX/2 May 20 - June 29, 1993) to the continental shelf of northeast Greenland (Fig. IV-1), our goals were to determine the microbial fate of carbon in the surface waters of the NEW Polynya and link it to the inorganic carbon cycle. Fig. IV-2 shows a schematic representation of the carbon pools and fluxes we considered, along with the techniques used to measure them. 


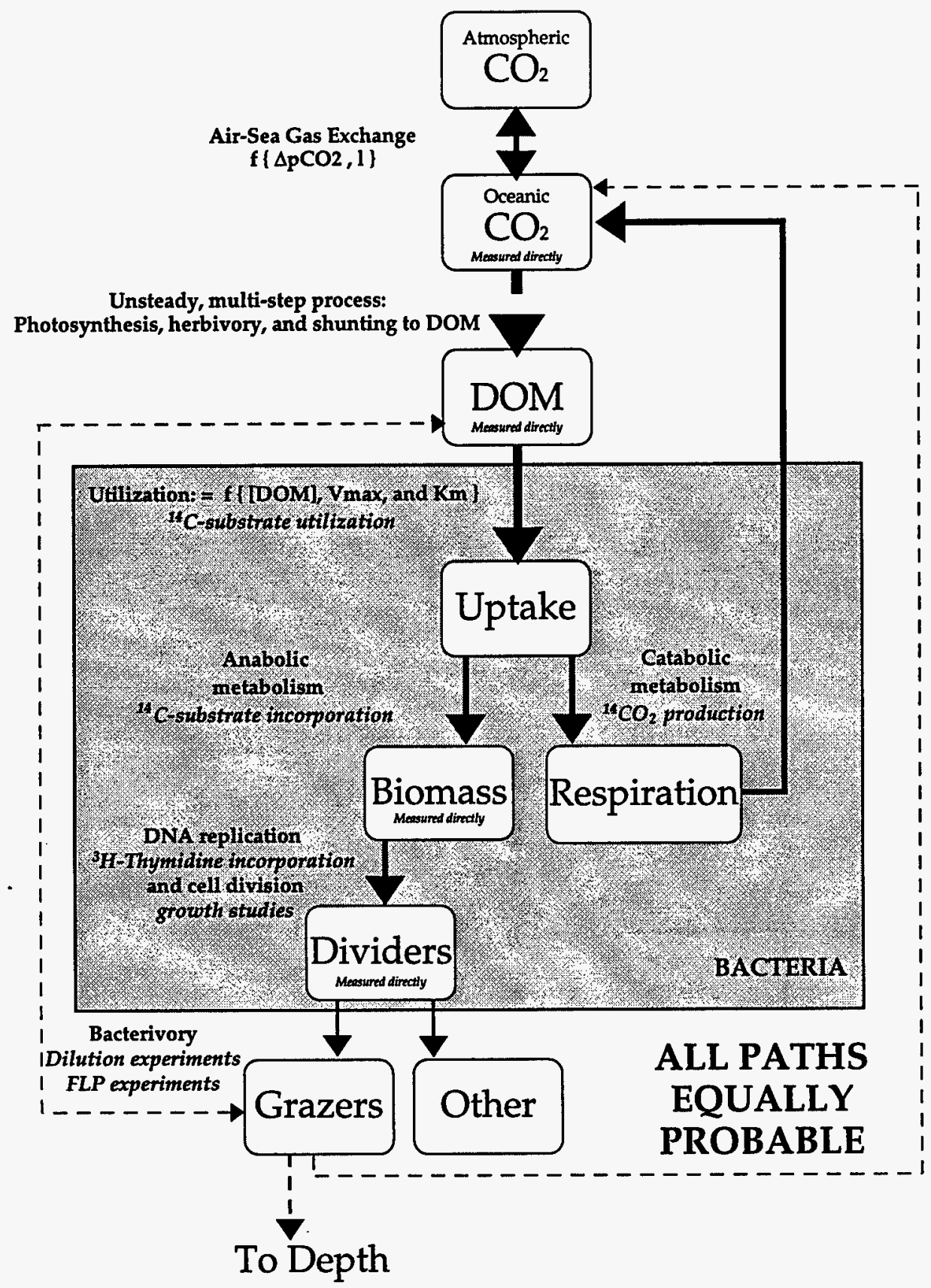

Figure IV-2. Mass-balance flow chart for polynya bacteria with methods used to measure illustrated stocks and fluxes; all fluxes equally probable. 
Seawater samples from the NEW Polynya were collected and subsampled as described in Chapter 3. DOM utilization was measured using a method modified from (Deming, 1993), originally developed by Wright and Hobbie (1966), using uniformly ${ }^{14}$ C-labeled substrates purchased from New England Nuclear (NEC-445E L-[14C(U)] amino acid mixture, $3.80 \mu \mathrm{mol} \mathrm{mCi}^{-1}$ or $218 \mu \mathrm{g} \mathrm{C} \mathrm{mCi}^{-1}$; NEC-279E L-[14C(U)] leucine, $314.8 \mathrm{mCi} \mathrm{mmol}^{-1}$; NEC290EL-\{14C(U)] glutamic acid, $261.6 \mathrm{mCi} \mathrm{mmol}^{-1}$; NEC-042X D-[14C(U)] glucose, $298.0 \mathrm{mCi} \mathrm{mmol}-1$ ). The prepared mixture of amino acids compared favorably $(r=0.83, \mathrm{P}<0.01)$ on a mole $\%$ basis with amino acid compositions of coastal marine phytoplankton (Cowie and Hedges, 1992). Substrates were added to final concentrations of $0.5,1,2,5,10,20,50$, or $100 \mathrm{nM}$. Samples were incubated in the dark, in temperature-controlled water baths $(-1.5,0,2,3.5$, or $5^{\circ} \mathrm{C}$ ) for time-course or end-point experiments ranging from 3 to $24 \mathrm{~h}$; the average in situ temperature for the fluorescence-maximum depths sampled was $-1.2^{\circ} \mathrm{C} \pm 0.66$. At the end of each incubation (including time-zero and $2 \%$ formaldehyde-killed controls), incorporation $\left({ }^{14} \mathrm{C}\right.$ incorporated to macromolecules captured on a $0.2-\mu \mathrm{m}$ Millipore filter) and respiration (determined as ${ }^{14} \mathrm{CO}_{2}$ extracted from seawater) were determined as described in Chapter 3. Incorporation efficiency (IE) was defined as the fraction of ${ }^{14} \mathrm{C}$ incorporation relative to total utilization $\left({ }^{14} \mathrm{C}\right.$-incorporation plus ${ }^{14} \mathrm{C}$ respiration). Standard curves and quench corrections for both data types making up the IE ratio were examined intensively to account for any differential effects on the ratio value. Quenching by the $\mathrm{CO}_{2}$-trapping PEA on the Whatman filter paper was greater than quenching by the Millipore filter, so respired counts-per-minute (CPM) needed to be corrected to disintegrationper-minute (DPM) to a greater extent $(x 1.08)$ than incorporated CPM to DPM 
(x 1.04). Because we were looking for an enhancement in efficiency, we processed the data conservatively so as to minimize IE (preferring Type I to Type II error, Sokal and Rohlf, 1981). Any enhancement seen is, therefore, an underestimate.

Bacterial biomass production was measured by the incorporation of ${ }^{14} \mathrm{C}$-radiolabeled leucine (New England Nuclear: NEC-279E L-[14 C(U)] leucine, $314.8 \mathrm{mCi} \mathrm{mmol}^{-1}$ ) into cold-TCA insoluble material (Kirchman, 1993). Substrate was added to $20-\mathrm{ml}$ seawater samples to a final concentration of 15 nM. Samples were capped and incubated in the dark, in temperaturecontrolled water baths at -1 or $-1.5^{\circ} \mathrm{C}$ (approximate in situ temperature) for time-course experiments ranging from 3 to $12 \mathrm{~h}$. At the end of each incubation (including time-zero and $2 \%$ formaldehyde-killed controls) activity was stopped using $0.1 \mathrm{ml}$ of $5 \mathrm{~N} \mathrm{NaOH}$. Samples were stored in the dark at $2^{\circ} \mathrm{C}$ for up to three months, as the ship returned to Seattle. Samples were processed by first adding $20 \mathrm{ml} 10 \%$ ice-cold TCA to the serum bottle, then gently filtering the sample through a $0.2-\mu \mathrm{m}$ nitrocellulose filter to collect the precipitate. The filter was then rinsed twice with $20 \mathrm{ml}$ of ice-cold $5 \% \mathrm{TCA}$ and once with $20 \mathrm{ml}$ of distilled water. Filters were transferred to scintillation vials and counted using Ecolume scintillation cocktail. Conversion from incorporated leucine to biomass production assumes no extracellular leucine, and uses $13.7 \mathrm{~g}$ protein $\mathrm{g}$ leucine ${ }^{-1}$ and $0.88 \mathrm{~g} \mathrm{C} \mathrm{g}$ protein $^{-1}$ (53.3 fg C and $60.6 \mathrm{fg}$ protein per $0.4 \mu \mathrm{m}^{3}$ cell; Simon and Azam, 1989).

Bacterial DNA production was measured using ${ }^{3} \mathrm{H}$-radiolabeled thymidine incorporation into the cold TCA-, chloroform-phenol-, and cold ethanol-insoluble fractions (Wicks and Robarts, 1987). Substrate (New 
England Nuclear: NET-027Z [Methyl-3H]-thymidine, $82.3 \mathrm{Ci} \mathrm{mmol}^{-1}$ ) was added to $20-\mathrm{ml}$ seawater samples to a final concentration of $15 \mathrm{nM}$. Samples were treated in a manner identical to the bacterial biomass production samples described above except for an additional rinse of $5 \mathrm{ml}$ of phenolchloroform $(50 \% \mathrm{w} / \mathrm{v})$ followed by two rinses of $5 \mathrm{ml}$ of ice-cold $80 \%$ ethanol. Conversion from incorporated thymidine to biomass was made using $2 \times 10^{18}$ cells mol thymidine ${ }^{-1}$ and $10 \mathrm{fg} \mathrm{C}$ cell $^{-1}$ (Ducklow and Carlson, 1992). These values range in the ocean from $1 \times 10^{17}$ to $60 \times 10^{18}$ cells mole ${ }^{-1}$ and 2 to 28 fg C cell-1 ${ }^{-1}$ respectively (Ducklow and Carlson, 1992), and thus the interpretation of our results will be quite sensitive to the choice we make for these conversion factors (see discussion).

We measured bacterivory and bacterial growth rate using the dilution method (Tremaine and Mills, 1987). One-liter samples were pre-filtered through a $200-\mu \mathrm{m}$ Nitex mesh and then diluted to $100,75,50$, and $25 \%$ of original concentration using gently-filtered $(0.2-\mu \mathrm{m})$ seawater from the same station and depth. Filtration was done using the lowest possible setting of a vacuum pump and frequent filters changes, yet some DOC enrichment may have still occurred due to cell breakage under vacuum. Time-zero samples were taken and then each bottle incubated for $24 \mathrm{~h}$ in the on-deck water table while screened to $5 \%$ ambient sunlight (bath temperature typically ranged from -1 to $0^{\circ} \mathrm{C}$ ). After incubation, samples were fixed and counted for bacterial abundance, as described in Chapter 3, to determine bacterial growth rate as a function of dilution factor. Grazing rate is taken from the slope of this relationship; bacterial growth rate in the absence of grazers is taken as the $y$-intercept. This technique is more commonly applied to measure herbivory by macrozooplankton, but can also be used to measure bacterivory (Tremaine 
and Mills, 1987, E. Lessard, personal communication). Subsamples for chlorophyll $a$ were taken from the same incubations simultaneously to determine rates of protozoan herbivory (Sime-Ngando et al., manuscript in preparation).

\section{Results}

14C-labeled substrates were taken up and respired at detectable levels for all substrate concentrations and incubation temperatures used for samples from the depths of maximum fluorescence. The efficiency at which cells incorporated substrate into biomass was remarkably consistent across all stations in the polynya except for those stations sampled aboard Polarstern earlier in the Spring of 1993 where IE tended to be lower.

Since IE measurements can be very sensitive to the technique used (Bjørnsen, 1986), particularly to the extent of radiolabel that enters the cell (and is only then capable of being respired) during incubation, we first examined the effects of incubation time and strength of the radioactive signal. Incorporation efficiency of mixed amino acids was not a significant function of incubation time $(P>0.1)$ over the range we measured $(4-16 h)$. Nor was it significantly sensitive to the strength of the signal as measured by pmol substrate utilized per liter of sample (i.e., the rate measurement before being scaled by time of incubation; P $>0.1)$. At very low signal strengths $(<500 \mathrm{pmol}$ liter $\left.^{-1}\right)$, however, there was more noise in the measurement: IE for mixed amino acids ranged from 30 to $100 \%$, although the average value (82\%) for all 1992 stations at low signal strength was not different from that measured at up to 9000 pmol liter $^{-1}$. These results provide some confidence that our estimates are valid and interpretable. 
For $10 \mathrm{nM}$ substrate additions incubated at in situ temperature over a total of eight stations in 1993, the uniformity of $\mathrm{IE}$ as a function of substrate type was remarkably high (Fig. IV-3). In general, leucine was used extremely efficiently, ranging from 90 to $100 \%$. Mixed amino acids were used slightly less efficiently, averaging $82 \pm 5 \%$. The efficiency on glucose averaged $68 \pm$ $4 \%$, while glutamic acid, which may go directly into the respiratory cycle, averaged $41 \pm 5 \%$.

Multivariate ANOVA was used, as with utilization rate in Chapter 3, to test for effects of temperature and substrate on incorporation efficiency. Overall, temperature and substrate explained an average of $71.6 \pm 11.8 \%$ of the variation in incorporation efficiency (i.e., the average $r^{2}=0.716 \pm 0.118 ; n=9$ ). In all but one of the nine stations analyzed, substrate had a significant effect $(P$ $<0.05$ ) on IE (Table IV-1). Station 92-56 was the exception; as we have already discussed in Chapter 3, this was the station with the highest DFAA concentrations. Again, high in situ substrate concentrations appear to dampen any substrate effects.

Temperature had a significant $(P<0.05)$ effect on IE in only three of the nine experiments (Table IV-1), two of which were visits to the time-series location. Of note is the fact that these two experiments (Stations $92-25 \mathrm{~B}$ and 93-30) also exhibited temperature effects on utilization rate (Table III-2). Combined effects of temperature with substrate were found at two of the nine stations. The heavily ice-covered station over the central bank (92-64) was the one station that showed an interaction between temperature and substrate concentration for both IE and utilization rate.

Examining the three-dimensional surface fits to IE as a function of temperature and substrate concentration, we detected significant non- 


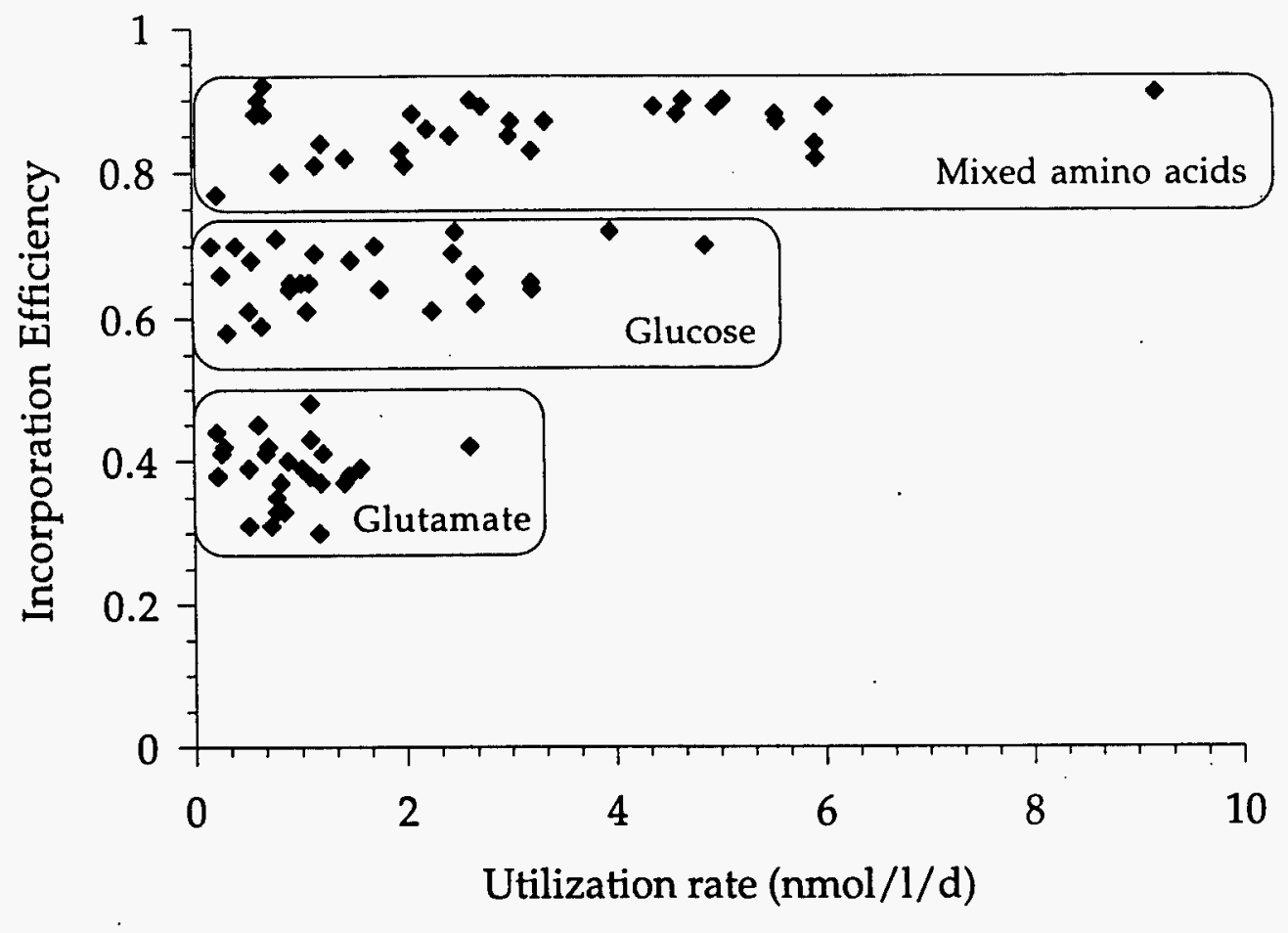

Figure IV-3. Incorporation efficiency versus utilization rate for seawater samples with $10 \mathrm{nM}$ added mixed amino acids, glucose, or glutamic acid, incubated at $-1.5^{\circ} \mathrm{C}$. 
128

TABLE IV-1: M(ANOVA) results for Incorporation Efficiency

\begin{tabular}{cccccc}
\hline Station & $\mathrm{n}$ & $\mathrm{R}^{2}$ & $\begin{array}{c}\mathrm{P} \\
\text { Added } \\
\text { Substrate }\end{array}$ & $\begin{array}{c}\mathrm{P} \\
\text { Temperature }\end{array}$ & $\begin{array}{c}\mathrm{P} \\
{[\mathrm{A}] \times \mathrm{T}}\end{array}$ \\
\hline \hline $92-25 \mathrm{~B}$ & 35 & 0.802 & $0.007^{* *}$ & $<0.001^{* *}$ & 0.258 \\
$92-43 \mathrm{~B}$ & 36 & 0.784 & $0.013^{* *}$ & $0.004^{* *}$ & $0.022^{* *}$ \\
$92-49$ & 36 & 0.683 & $0.001^{* *}$ & 0.829 & 0.736 \\
$92-56$ & 35 & 0.555 & 0.664 & 0.096 & 0.313 \\
$92-64$ & 36 & 0.888 & $<0.001^{* *}$ & 0.147 & $0.035^{*}$ \\
$93-30$ & 50 & 0.755 & $<0.001^{* *}$ & $0.013^{* *}$ & 0.406 \\
$93-43$ & 52 & 0.627 & $<0.001^{* *}$ & 0.736 & 0.331 \\
$93-85$ & 54 & 0.553 & $0.002^{* *}$ & 0.074 & 0.210 \\
$93-2$ & 53 & 0.801 & $<0.001^{* *}$ & 0.344 & 0.664 \\
\hline
\end{tabular}

* Indicates significance at $\geq 95 \%$ confidence.

** Indicates significance at $\geq 99 \%$ confidence. 
linearity in the surfaces. For improved visualization, we plotted respiration efficiency (RE \% = $100-\mathrm{IE} \%$ ) for each station (Figure IV-4). Incorporation efficiencies tended to drop with higher substrate concentrations, perhaps indicating luxury consumption or less tendency for storage.

Bacterial protein production measured using leucine (BP-LEU) ranged from 0 to $12 \mu \mathrm{g} \mathrm{C}^{-1} \mathrm{~d}^{-1}$ (with the median rate at $0.54 \mu \mathrm{g} \mathrm{Cl}^{-1} \mathrm{~d}^{-1}$ for 1992 stations and $2.61 \mu \mathrm{g} \mathrm{Cl}^{-1} \mathrm{~d}^{-1}$ for 1993). This production equaled, on average, about $20-25 \%$ of primary production rates for the same depth and station (Figure IV-5; the slope of the linear regression was $0.20 \pm 0.04$ for all stations, although the $\mathrm{r}^{2}$ value, 0.08 , was not significant). There were a few stations where primary production was low and bacterial production high $192-25 \mathrm{~B}$ and 93-86), and vice versa (particularly at the time series location in 1993: 93-2, 9317 , and 93-37), indicating that the two processes were often decoupled in the polynya region.

Bacterial production using thymidine incorporation into DNA (BPTDR) ranged from 0 to $9.0 \mu \mathrm{g} \mathrm{Cl}^{-1} \mathrm{~d}^{-1}$ (with the median rate for 1992 at 0.23 , and for 1993, $\left.1.63 \mathrm{\mu g} \mathrm{Cl}^{-1} \mathrm{~d}^{-1}\right)$, if we assumed the oceanic median genome size ( $2 \times 10^{18}$ cells mol thymidine ${ }^{-1}$; Ducklow and Carlson, 1992) and applied the large cell biovolume found in the polynya (Chapter 3; $0.525 \mu \mathrm{m}^{3}$ ) with the cell carbon to biovolume ratio determined by Simon and Azam (1989; $60 \mathrm{fg} \mathrm{C}$ cell $^{-1}$ for a cell size greater than $0.4 \mu \mathrm{m}^{3}$ ). Compared to the BP-LEU estimates, which do not require a cell biomass to biovolume assumption, BP-TDR rates were about the same or lower (BP-LEU : BP-TDR ratio had a median of 1.56 and ranged from 0.03 to 81 ) and exceeded the BP-LEU rates at only a few stations (Fig. IV-6). The estimated BP-TDR rates were significantly reduced if we instead used a theoretical genome size (ca. $0.5 \times 10^{18}$ cells mol thymidine ${ }^{-1}$ ) 
Figure IV-4. Three-dimensional surface plots of percent respiration $(R=1-I E)$ versus temperature $\left(T^{\circ} \mathrm{C}\right)$ and added substrate concentration ([A]): a) Station 92-25B; b) Station 92-43B; c) Station 92-49; and d) Station 92-56. 
a.

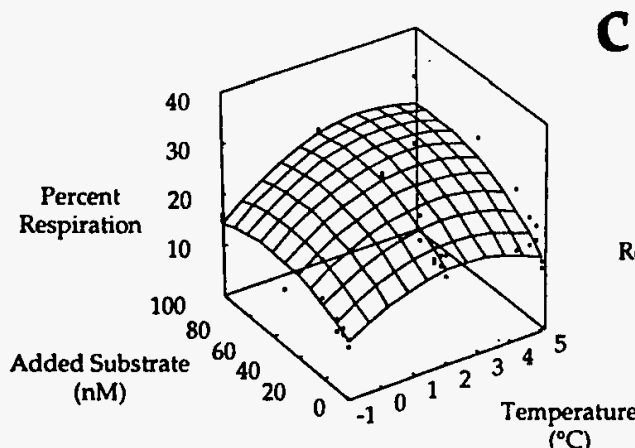

c.

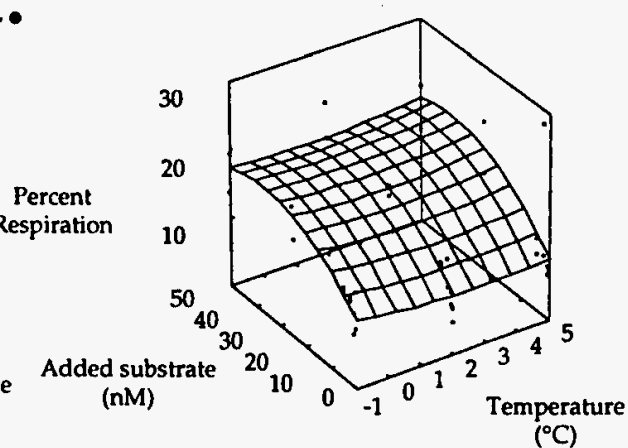

b.
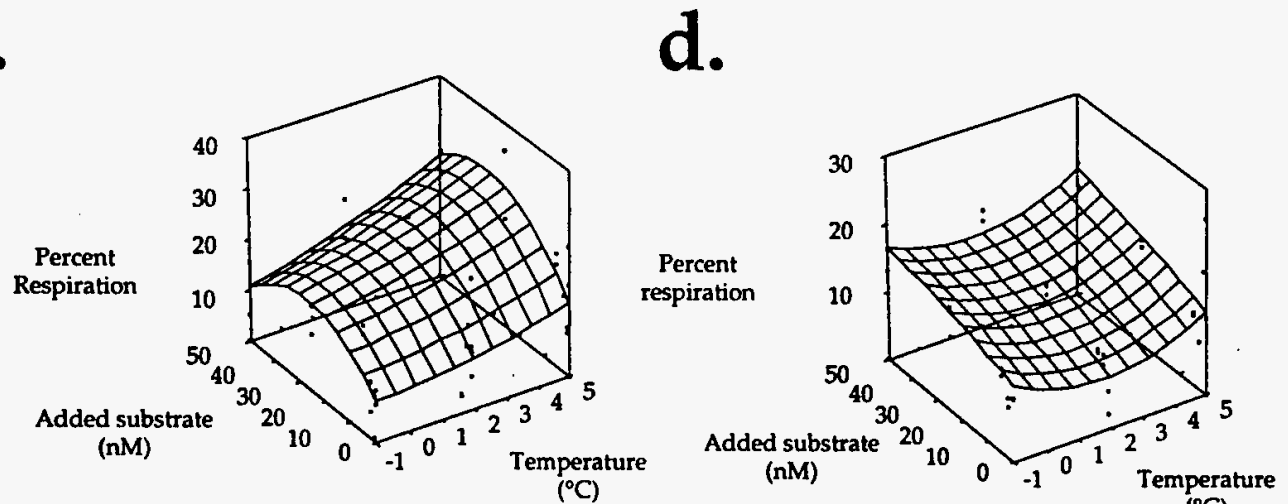

( $\left.{ }^{\circ} \mathrm{C}\right)$ 
132

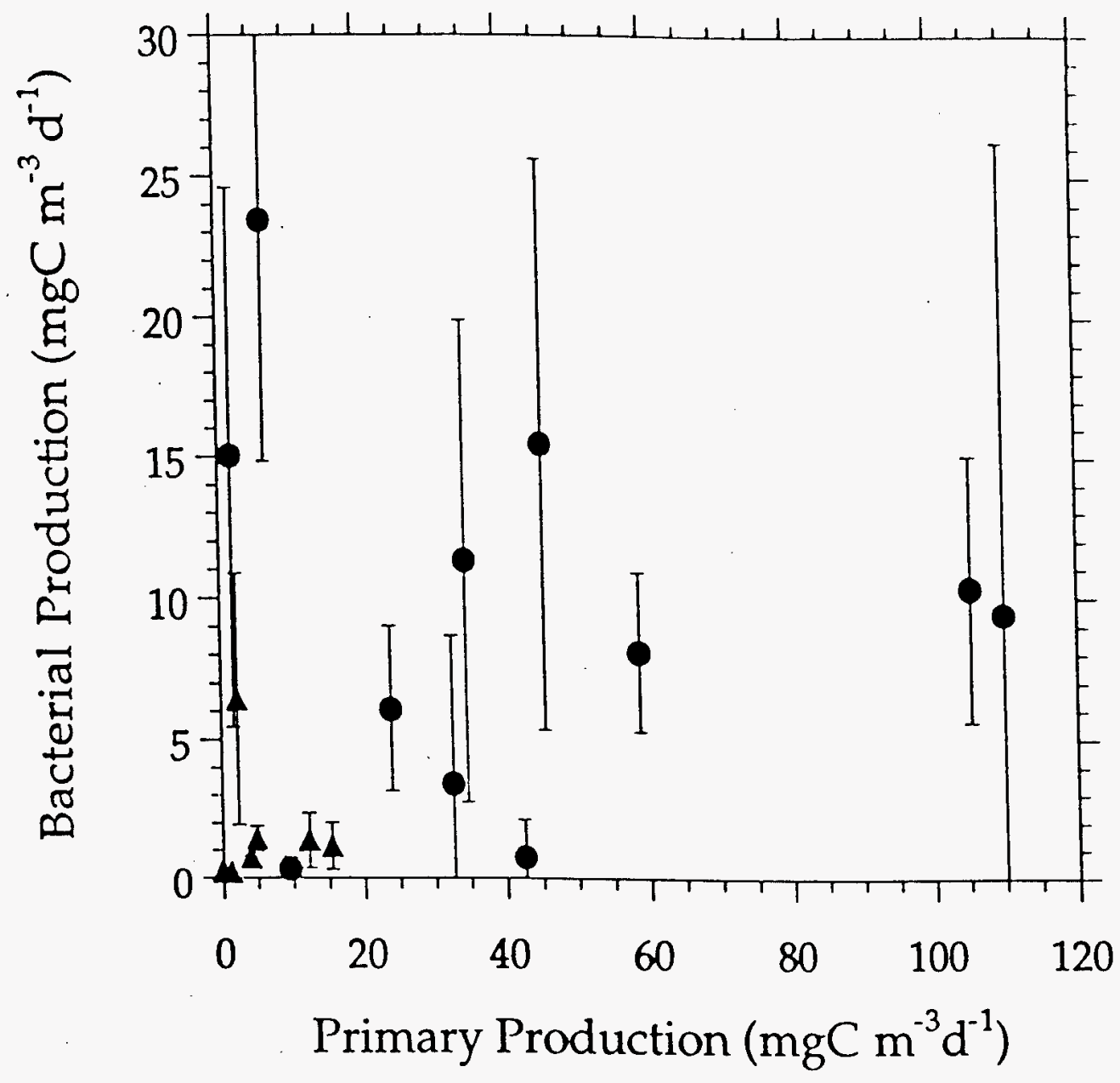

Figure IV-5. Bacterial production measured by ${ }^{14} \mathrm{C}$-leucine incorporation into TCA insoluble biomass $\left(\mathrm{mg} \mathrm{C} \mathrm{m} \mathrm{C}^{-3} \mathrm{~d}^{-1}\right)$ as a function of primary production ( $\mathrm{mg} \mathrm{C} \mathrm{m}^{-3} \mathrm{~d}^{-1}$; data courtesy of W. O. Smith) in the euphotic zone. Circles indicate stations measured in 1993, and triangles in 1992. Error bars indicate one. standard error on slope (rate) estimate from time course or endpoint experiments. 


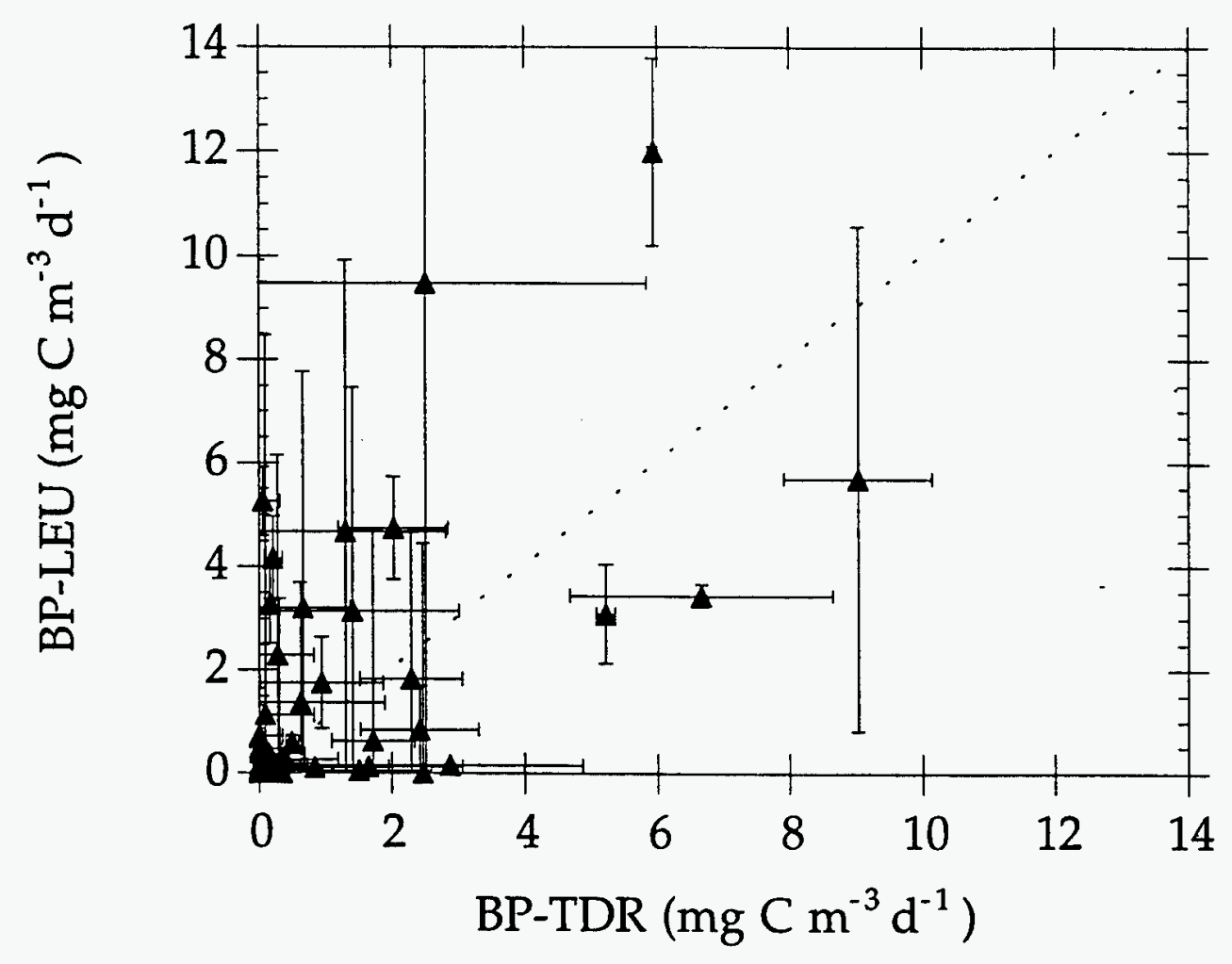

Figure IV-6. Bacterial production estimated by ${ }^{3} \mathrm{H}$-thymidine incorporation to DNA ( $m g \mathrm{C} \mathrm{m}^{-3} \mathrm{~d}^{-1}$ ) versus bacterial production estimated by ${ }^{14} \mathrm{C}$-leucine incorporation into protein $\left(\mathrm{mg} \mathrm{C} \mathrm{m}^{-3} \mathrm{~d}^{-1}\right)$. Error bars indicate one standard error on slope (rate) estimates from time course or endpoint experiments. 
or a more typical cell biomass (e.g., $10 \mathrm{fg}$ C cell-1; Ducklow and Carlson, 1992). In both cases, the production estimates would drop below those determined by leucine incorporation and indicate "unbalanced" growth (Kirchman et al., 1986; see Discussion).

Bacterivory ranged from 0 to $3.7 \mathrm{~d}^{-1}$ (using specific growth rates; up to 5 $\mu \mathrm{g} \mathrm{Cl}^{-1} \mathrm{~d}^{-1}$ if we convert to carbon) and in general kept pace (Fig. IV-7) with bacterial growth estimated using the $y$-intercept of the dilution curve (theoretical growth rate in the absence of grazers). These bacterial growth rates, estimated using the dilution technique, compared reasonably well to the potential growth rates described in Chapter 3 and to the bacterial production rates described above.

If we subdivide our Polarstern cruise stations into the two ecosystem types suggested by Pesant et al., (1995; using the size-fractionated phytoplankton biomass and production to divide the polynya stations into those ecosystems dominated by large diatoms, Type I, and those dominated by small autotrophic flagellates, Type V), we find that bacterivory tends to equal or exceed bacterial growth at Type V stations $(n=5)$ but fall short of growth at Type I stations ( $n=4$; Fig. IV-8). According to Legendre and LeFevre (1995), these ecosystem types indicate the local importance of the microbial loop, with Type I reflecting an herbivorous food web and Type $\mathrm{V}$ reflecting a microbial food web or loop. Our data confirms this idea in that a stronger link between bacterial growth and bacterivory occurs where autotrophic flagellates dominate. In an herbivorous food web, bacteria are active, but apparently not as strongly controlled by microzooplankton grazers. 


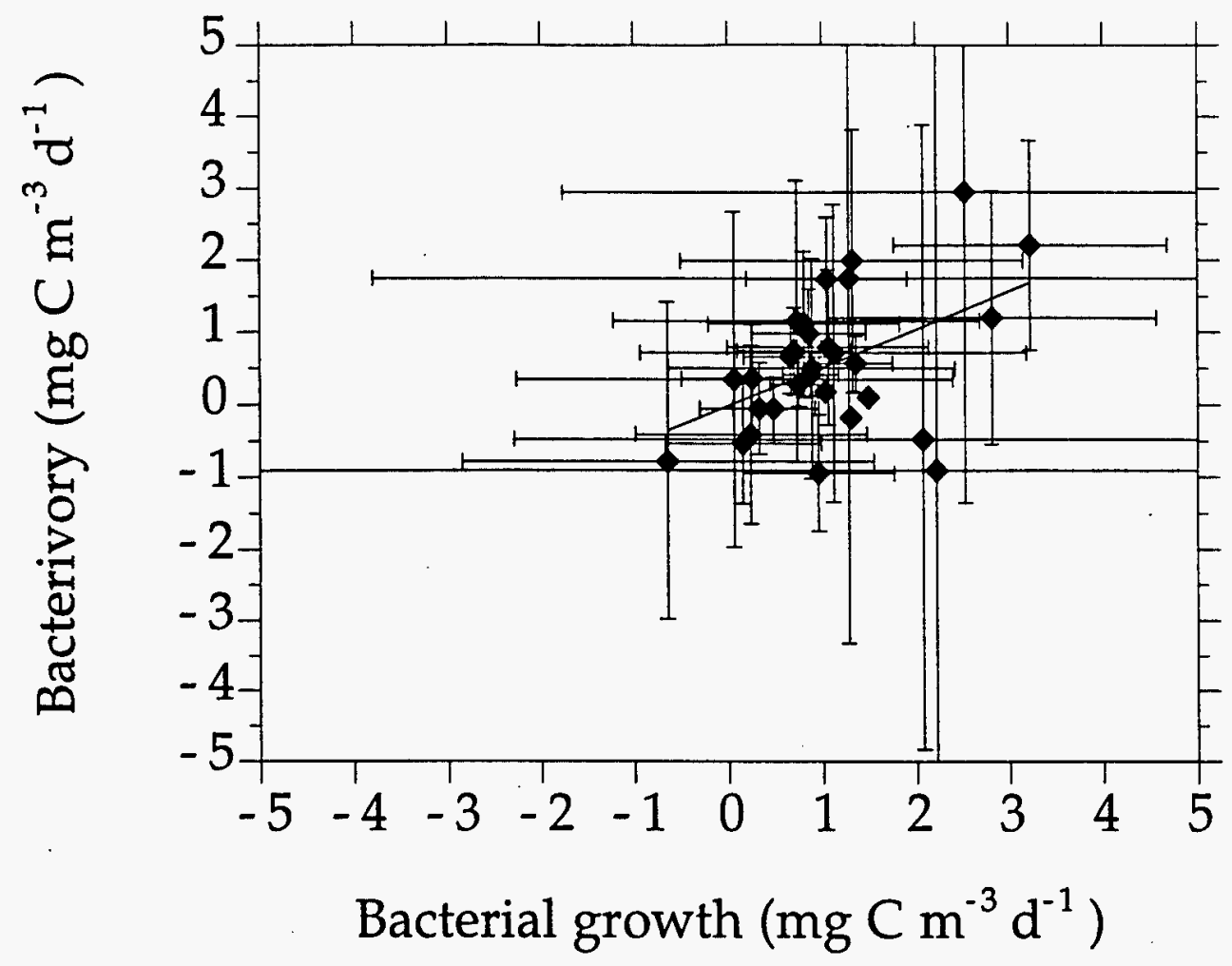

Figure IV-7. Grazing rate ( $g b, \mathrm{mg} \mathrm{C} \mathrm{m}^{-3} \mathrm{~d}^{-1}$; estimated by the slope) as a function of bacterial growth in the absence of grazers $\left(\mu, \mathrm{mg} \mathrm{C} \mathrm{m}^{-3} \mathrm{~d}^{-1}\right.$; estimated by the $y$-intercept) determined from the dilution versus bacterial growth relationship. Conversion of growth rate from units of $\mathrm{d}^{-1}$ to $\mathrm{mg} \mathrm{C} \mathrm{m}^{-}$ $3 \mathrm{~d}^{-1}$ assumes $60 \mathrm{fg} \mathrm{C}^{\mathrm{C}}$ cell $^{-1}$ (see text) and uses the measured bacterial abundance for each station (see Table III-1). 


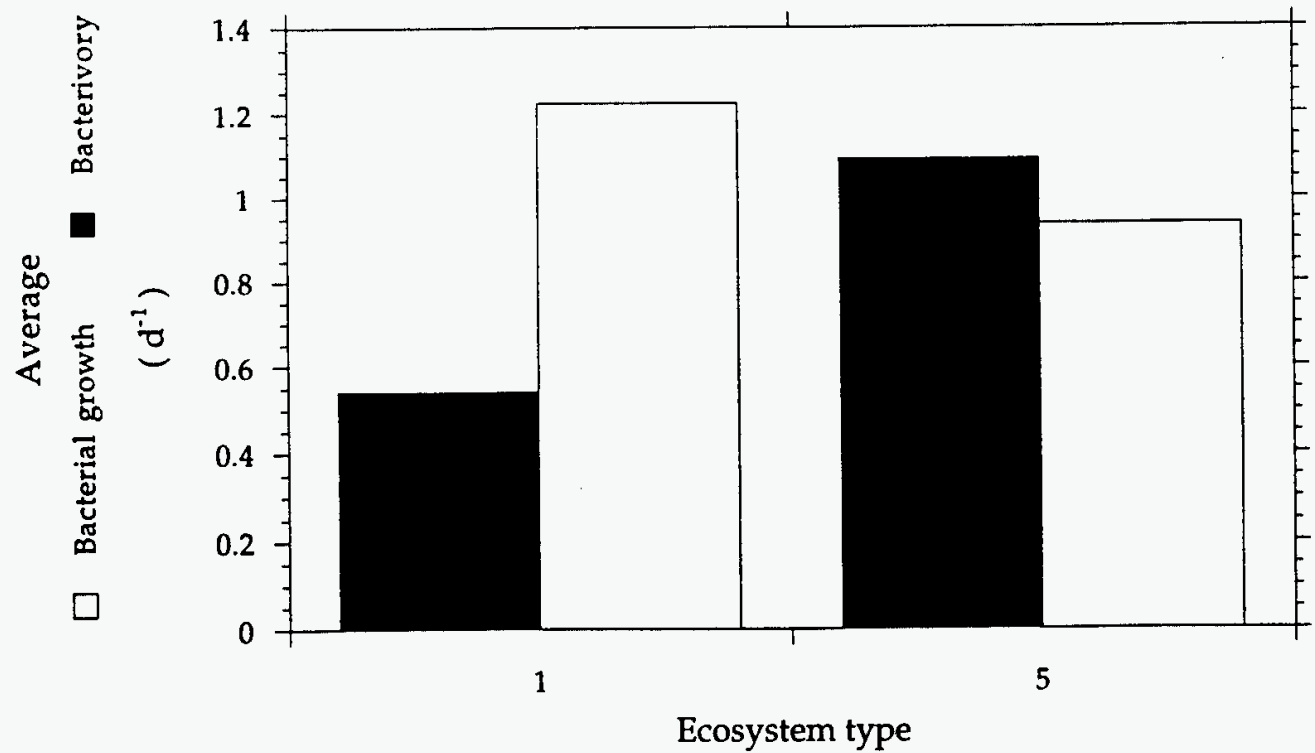

Figure IV-8. Average bacterial growth and bacterivory for Polarstern 1993 stations subdivided into Type I ecosystems (diatom-dominated; $\mathrm{n}=5$ ) and Type V ecosystems (autotrophic flagellate-dominated; $n=4$ ). Under conditions favoring the microbial loop, bacterivory tends to dominate bacterial growth. (Because of the small number of stations, however, error bars are $\pm>100 \%$; we can only infer a trend.) 


\section{Discussion}

Taken together, this suite of results points to the conclusion that bacteria in the NEW Polynya were taking up dissolved organics as they became available, using them efficiently with minimal respiration, and passing the carbon and energy to higher trophic levels (Fig. IV-9). Some of these carbon transfers may also be sensitive to warming and could feedback to perturbations of the inorganic carbon cycle.

Why do these results appear so different from the paradigm that the microbial loop is inactive in polar waters? One explanation may be that unique strategies adopted by high-latitude bacteria are underestimated by traditional methods. Previous attempts to measure bacterial activity at high latitudes have often relied solely on measurements of respiration $\mathrm{CO}_{2}$ utilization or $\mathrm{CO}_{2}$ production) or on thymidine incorporation into DNA. According to our data, Arctic bacteria may not expend much of their limited energy on respiration and bacterial production measured with thymidine incorporation may be underestimated if standard conversion factors are used (see below).

Why the metabolic partitioning of organic matter by polar bacteria should be different from temperate organisms is not entirely clear, unless we assume that oligotrophic strategies are especially successful in the polar environment. If there is a link between psychrophily and oligotrophy in the marine environment (Zobell, 1946), it should be detected most clearly in polar environments. High efficiencies may be related to the episodic nature of the polar food source (and resultant adaptations associated with oligotrophy, e.g., storage) or to community structure (i.e., if psychrophiles are more efficient 


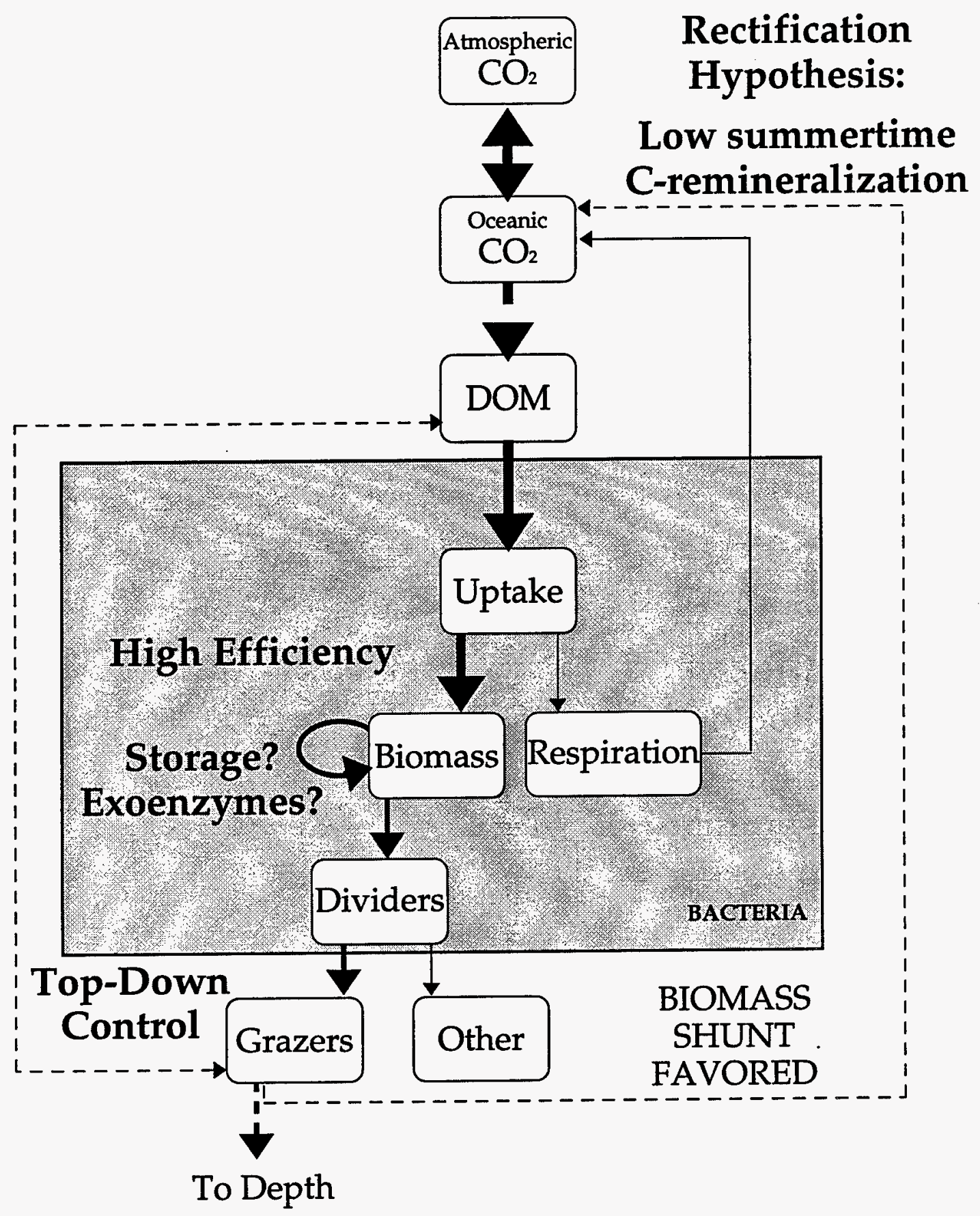

Figure IV-9. Mass-balance figure redrawn, showing overall conclusion from this study that the biomass shunt is favored in the NEW Polynya over carbon respiration; arrows are proportional. 
than psychrotolerant or mesophilic bacteria, the dominance of psychrophiles under some incubation conditions might be reflected in our observations). High polar efficiency as a strategy for survival is further supported by recent data from the Alaskan Arctic showing that high-latitude methane oxidation is also highly efficient ( $60 \%$, E. McLaughlin, personal communication). High incorporation efficiencies and unbalanced growth may also be a response to grazing pressure if larger cell size does provide more of a refuge from predation (Chapter 3).

There is some discussion in the literature about the validity of using radiolabeled substrates to measure growth efficiency (see for example, the review by Pomeroy and Wiebe, 1993). Bacterial incorporation of 14C-labeled substrates appears to be more efficient than that observed on a more "natural" mix of dissolved organic matter (e.g., Linley and Newell, 1984) or than that determined by the ratio of net biomass production relative to the sum of respiration $\left(\mathrm{CO}_{2}\right)$ and net biomass production (e.g., Bjørnsen, 1986). Bacteria gain more benefit from taking up an amino acid than a less labile organic molecule, and may therefore utilize it differently (e.g., more efficiently). Since bacteria are known to be capable of diauxic growth (as originally proposed by Monod, 1942), they can be expected to regulate their uptake processes so as to utilize the better substrate first when confronted with resources of diverse quality; i.e., as NEW Polynya bacteria encounter amino acids, they will prefer them to other less labile material. By using a mixture of amino acids that mimics the composition of phytoplankton or zooplankton exudate, we expected our results to reflect "reality" better than if we had used a single substrate. Nevertheless, if the bacteria in the polynya are not regularly exposed to such a labile food supply, we measured their behavioral 
responses to high quality food pulses and not some "average" condition. Since our goal was a comparative one (temperature and substrate concentration effects on efficiency), we can still draw conclusions about the sensitivity of this microbial response. Generalizing our results to the overall carbon cycle of the polynya should await better understanding of controls on DOM production in the region.

Interpretation of bacterial production data is also challenging. Because of the unusually large cell sizes in the polynya, particularly the fact that a high percentage $(72 \pm 6.5 \%)$ of cells were rod-, spiral-, or crescent-shaped (Chapter 3), rather than tiny cocci, the choice of conversion factors becomes a dilemma. The thymidine technique works best in oligotrophic environments when cells are uniformly small and contain a single genome (J. Baross, pers. comm.). Once cells become large and active, the genome-to-carbon ratio can fluctuate a great deal and make interpretation difficult. Data from other arctic environments, where measurements were made frequently throughout the year (Rivkin, 1994), indicate that conversion factors can vary several orders of magnitude depending on the season. Given the problems with conversion, we cannot be certain that bacterial growth in the polynya was either balanced or unbalanced. The appearance of unbalanced growth, however, indicates a microbial community out of steady state, a finding that supports the idea that high-latitude bacteria may have unusual survival strategies for their extremely heterogeneous environment.

Under conditions of nitrogen limitation, bacteria store carbon energy in the form of long-side-chain polyhydroxyalkanoate (PHA; Ramsay et al., 1992). Temperature (Huijberts et al., 1992) and unsteady food supply (Pagni et al., 
1992) can also influence PHA production. Carbon storage due to these or other factors may explain our observations of high incorporation efficiency.

Extracellular enzyme production may also increase at low temperatures (Reichardt, 1991). If such enzymes were produced from the radiolabeled substrate added in our experiments and also exhibited the high binding affinities to particle surfaces predicted from modeling exercises (Vetter and Deming, 1996), they may have been retained on the $0.2-\mu \mathrm{m}$ filter and thus contributed to the measures of high incorporation efficiency.

From this study, pelagic bacteria in the polynya appear to be highly responsive to pulses of labile organic matter (Chapter 3 ) and very efficient at retaining it in the organic carbon pool, releasing only a small fraction of it to respiration (this chapter). Bacterial biomass does not accumulate, however, because the cells are, by all measures (Fig. III-3 and Fig. IV-7), living under intense grazing pressure. An obvious question arises: given that bacteria have minimized respiration in this and perhaps other polar environments, do the bacterivores play a more dominant role than their prey in carbon and nitrogen remineralization? The only study of the growth efficiency of polar heterotrophic flagellates, of which I am aware, is that by Choi and Peters (1992). In this study using cultured organisms, IE was high at subzero temperatures (60-70\%) and decreased with warming, much as we observed in some of our experiments in the polynya. If these flagellate results can be extrapolated to other grazers in polar waters, then highly efficient trophic links may continue up the food web, providing an ecosystem response that contributes as a whole to an efficient biological pump. 
142

Conclusions

We found active and responsive microbial populations at the fluorescence maxima of the NEW Polynya surface waters. High incorporation efficiencies on labile organic matter suggest that polynya bacteria reserve rather than quickly metabolize (catabolize) favored food sources and may have evolved survival strategies for dealing with episodic food availability, nitrogen limitation, and grazer control. Incorporation efficiencies tended to drop with higher substrate concentrations, perhaps indicating luxury consumption. When sensitive to temperature, IE showed a varied response, showing a decrease with warming at some stations, but highly non-linear and non-monotonic responses at others. Unbalanced growth was observed (subject to choice of conversion factors), with a tendency towards biomass building consistent with the large cell size observed. This behavior may reflect a storage response to episodic food supply or a refuge response to grazing pressure given the role of size in determining predatorprey encounter efficiency. Bacterivory was patchy but accounted for $25->100 \%$ of bacterial growth when detected by the dilution method, suggesting that bacteria provide a link to higher trophic levels when there is sufficient food available for bacterial growth. This link may be enhanced in those communities dominated by the microbial loop. We suggest that the biological pump functions with high efficiency in polar environments not because the microbial community is inactivated by low temperature, but rather because active psychrophilic microbial communities minimize summertime respiration of labile organic carbon as a survival strategy in the face of an episodic food supply and significant grazing pressure. 


\section{Overall Conclusions and Future Research Plans}

The fundamental conclusion derived several times from this research project is that mechanisms exist by which high-latitude marine biota may feedback to global climate change via their effects on the inorganic carbon cycle. These mechanisms include 1) non-steady state behavior in the temporally and spatially heterogeneous environment of the high-latitude seas; 2) interactions between marine biota and their physical environment (particularly with respect to timing) which influence the extent to which icecover can act as a wintertime lid to outgassing of $\mathrm{CO}_{2}$; and 3) temperature and food source effects on microbes which can influence the strength and efficiency of the biological carbon pump.

In Chapter 1, the sensitivity of local air-sea carbon flux to small changes in a single biological parameter was shown using a food web model linked to a simple ocean and atmosphere. Field data collected for Chapter 2 from the Northeast Water (NEW) Polynya confirmed that there were indeed significant biologically mediated inorganic carbon deficits in the summertime surface waters. This drawdown, put into the context of the seasonal cycle of ice-cover and wind speed, suggests that because of the marine biota, there is no time during the year when seasonally ice-covered seas can be a source of $\mathrm{CO}_{2}$ to the atmosphere. Due to this effect, these regions likely function as efficient biological pumps, sequestering carbon from the atmosphere. Because of strong cloud and ice-albedo feedbacks at high latitudes, the temperature sensitivity of the polar regions is acute and the global area of seasonally icecovered seas is expected to vary with natural and anthropogenically driven

climate change. If the results we found in our study area can be applied to 
these other regions, a small but significant negative feedback to climate change can be identified.

The above described scenario depends on low respiration rates during the productive summer season. These low respiration rates have been attributed historically to a disproportionate shut-down of the microbial remineralizers at sub-zero temperatures compared to the primary producers in polar regions. The mechanism for this shut down was thought to be an inability on the part of bacteria to acquire food in the form of low concentrations of organic matter, either because of the physiological challenges of this process at low temperature, or because diffusion rates of dissolved material were reduced significantly by the temperature effect on seawater density and viscosity. This study has shown that neither explanation is correct for all microbial communities sampled in the Northeast Water Polynya. In fact, there are indications that the microbial communities living in these regions are dominated by psychrophilic (coldloving) bacteria and that, for some, acquisition of dissolved organic matter is fastest at sub-zero temperatures compared to just a few degrees warmer (Chapter 3).

If the microbial communities are active, then why are the respiration rates so low in this region? One possibility supported by our data is that the active bacteria are not respiring much of the carbon they use, preferring to store it in response to either an episodic food supply or heavy grazing pressure. Since grazing pressure was indeed heavy, particularly at those stations where microbial loop processes were most developed, the biomass stored in the bacteria is likely transferred to the bacterivores rather than returned to inorganic form by significant respiration. Thus, an active and 
responsive bacterial community can still contribute to an efficient biological carbon pump at high latitudes.

Still, we are left with the question of what will happen when the Arctic warms up. Will the one-way sink remain intact as the area of seasonally icecovered regions increases and thus help ameliorate climate change forces? Will the warmer surface waters shift the microbial remineralization response, perhaps negating the rectification? Since we observed more than one response to temperature from communities sampled across a fairly small region, we are as yet unable to predict the final outcome.

Future research on this question of prediction requires two approaches, a theoretical and an experimental one. As described at the end of Chapter 1, many questions remain to be addressed using modeling, in particular the question of how the biologically mediated carbon flux can influence long term sequestration of carbon from the atmosphere, specifically for the case of anthropogenically enhanced concentrations of $\mathrm{CO}_{2}$. For the case of increasing temperature, we need to be able to predict which of the potential biotic feedbacks will dominate. This can be accomplished best through focused modeling exercises.

To determine the extent of phenotypic and genotypic diversity of microorganisms in polar seas requires an experimental approach. In order to better predict the response of microbial communities to warming, we need to know the players, how each responds to temperature, and what controls their activity with respect to other organisms in the same area. Molecular methods used to identify and distinguish in situ microorganisms genotypically, followed by laboratory work with pure cultures to distinguish ecologically relevant phenotypes, will be very helpful in this quest. 


\section{LIST OF REFERENCES}

Ambrose, W. G., Jr., and P. E. Renaud (1995). Benthic response to water column productivity patterns: evidence for benthic-pelagic coupling in the Northeast Water Polynya, J. Geophys. Res., 100: 4411-4422.

Amy, P. S., C. Pauling, and R. Y. Morita (1983a). Starvation-survival processes of a marine Vibrio, Appl. Env. Microbiol., 45: 1041-1048.

Anderson, L. G., and D. Dyrssen (1981). Chemical constituents of the Arctic Ocean in the Svalbard area, Oceanol. Acta, 4: 305-311.

Anderson, L. G., D. Dyrssen, and E. P. Jones (1990). An assessment of the transport of atmospheric $\mathrm{CO}_{2}$ into the Arctic Ocean, J. Geophys. Res., 95: 1703-1711.

Andrews, P., and P. J. Le B. Williams (1971). Heterotrophic utilization of dissolved organic compounds in the sea, J. Mar. Biol. Ass. U.K., 51: 111125.

Antia, N. J., C. D. McAllister, T. R. Parsons, K. Stephens, and J. D. H. Strickland (1963). Further measurements of production using a largevolume plastic sphere, Limnol. Oceanogr., 8: 166-183.

Antoine, D. , and A. Morel (1995a). Modeling the seasonal course of the upper ocean pCO2 (I). Development of a one-dimensional model, Tellus, 47B: 103-121.

Antoine, D., and A. Morel (1995b). Modeling the seasonal course of the upper ocean PCO2 (II). Validation of the model and sensitivity studies., Tellus, 47B: 122-144.

Armstrong, R. A. (1994). A simplified pelagic ecosystem model calibrated with BATS data; ABSTRACT, Proceedings of the 1994 Ocean Sciences Meeting, San Diego, CA, J. A F Spilhaus, San Diego, 100.

Ashjian, C. J., S. L. Smith , and P. V. Z. Lane (1995). The Northeast Water Polynya during summer 1992: distribution and aspects of secondary production of copepods., J. Geophys. Res., 100: 4371-4388. 
Azam, F., T. Fenchel, J. G. Field, J. S. Gray, L. A. Meyer-Reil , and F. Thingstad (1983). The ecological role of water-column microbes in the sea, Mar. Ecol. Prog. Ser., 10: 257-263.

Bacastow, R., and E. Maier-Reimer (1990). Ocean-circulation model of the carbon cycle, Clim. Dynam., 4: 95-125.

Banse, K. (1974). On the interpretation of data for the carbon-to-nitrogen ratio of phytoplankton, Limnol. Oceanogr., 19: 695-699.

Banse, K. (1994). Uptake of inorganic carbon and nitrate by marine plankton and the Redfield ratio, Global Biogeochem. Cycles, 8: 81-84.

Baross, J. A., and R. Y. Morita (1978). Microbial life at low temperatures: ecological aspects, in Microbial life in extreme environments, D. J. Kushner, ed., Academic Press, London, pp. 9-71.

Berger, W. H., V. S. Smetacek, and G. Wefer (1989). Ocean productivity and paleoproductivity--an overview, in Productivity of the ocean: present and past , W. H. Berger, et al., ed(s)., John Wiley \& Sons, pp. 1-34.

Berman, T. (1991). Protozoans as agents in planktonic nutrient cycling, in Protozoa and Their Role in Marine Processes , P. C. Reid, et al., ed(s)., Springer-Verlag, Berlin, pp. 417-429.

Billen, G. (1990). Delayed development of bacterioplankton with respect to phytoplankton: a clue for understanding their trophic relationships. Arch. Hydrobiol. Beih. Ergebn. Limnol. 114: 415-4299.

Billen, G. , and S. Becquevort (1991). Phytoplankton-bacteria relationship in the Antarctic marine ecosystem, Polar Res., 10: 245-253.

Bjørnsen, P. K. (1986). Bacterioplankton growth yield in continuous seawater cultures, Mar. Ecol. Progr. Ser., 30: 191-196.

Böhm, E. B., P. J. Minnett, and T. S. Hopkins (1996). Passive microwave observations of the interannual variability of ice cover in the NEWP: 1979-1991, J. Mar. Syst., in press. 
Boyd, P., and P. Newton (1995). Evidence of the potential influence of planktonic community structure on the interannual variability of particulate organic carbon flux., Deep Sea Res., 42: 619-639.

Bourke, R. H., J. L. Newton, R. G. Pacquette, and M. D. Tunnicliffe (1987). Circulation and water masses of the East Greenland Shelf, J. Geophys. Res., 92: 6729-6740.

Bradshaw, A. L., P. G. Brewer, D. K. Shafer, and R. T. Williams (1981). Measurements of total carbon dioxide and alkalinity by potentiometric titration in the GEOSECS program, Earth Planet. Sci. Lett., 55: 99-115.

Brewer, P. G., A. L. Bradshaw, and R. T. Williams (1986). Measurements of total carbon dioxide and alkalinity in the North Atlantic Ocean in 1981, in The Changing Carbon Cycle: A Global Analysis, edited by J. R. Trabalka and D. E. Reichle, Springer-Verlag, New York, pp. 348-370.

Broecker, W. S. (1991). Keeping global change honest, Global Biogeochem. Cycles, 5: 191-192.

Broecker, W. S. , and T.-H. Peng (1974). Gas Exchange rates between air and the sea, Tellus, 26: 21-35.

Broecker, W. S. , and T.-H. Peng (1982). Tracers in the Sea, Lamont-Doherty Geological Observatory, Palisades, NY, 690 pp.

Broecker, W. S., and T.-H. Peng (1989). The cause of the glacial to interglacial atmospheric $\mathrm{CO}_{2}$ change: A polar alkalinity hypothesis, Global Biogeochem. Cycles, 3: 215-239.

Broecker, W. S., and T.-H. Peng (1992). Interhemispheric transport of carbon dioxide by ocean circulation, Nature, 356: 587-589.

Broecker, W. S., T. Takahashi, H. J. Simpson, and T.-H. Peng (1979). Fate of fossil fuel carbon dioxide and the global carbon budget, Science, 206: 409-418.

Budéus, G., and W. Schneider (1994). Data report on CTD-measurements during ARK IX/2+3, in 1993 NEW Expedition. Appendix to Data Report of RV Polarstern cruises ARK IX/2+3 to the Northeast Water, 
edited by H.J. Hirche and G. Kattner, Alfred-Wegener-Institut für Polar- und Meeresforschung, Bremerhaven, Germany.

Button, D. K. (1985). Kinetics of nutrient-limited transport and microbial growth, Microbiol. Rev., 49: 270-297.

Button, D. K. (1991). Biochemical basis for whole-cell uptake kinetics: specific affinity, oligotrophic capacity, and the meaning of the Michaelis constant, Appl. Env. Micro., 56: 2033-2038.

Button, D. K. (1994). The physical basis of marine bacterial ecology, Microb. Ecol., 28: 273-285.

Carberry, J. J. (1976). Chemical and catalytic reaction engineering, McGrawHill, New York.

Carlson, C. A., H W Ducklow, D. A. Hansell (1996). Assessing the lability of the dissolved organic pool in the Sargasso Sea and the Ross Sea. ABSTRACT. 1996 Ocean Sciences Meeting, American Geophysical Union / American Society of Limnology and Oceanography, San Diego, February 1996.

Caron, D. A. (1991). Evolving role of protozoa in aquatic nutrient cycles, in Protozoa and Their role in Marine Processes, P. C. Reid, et al., ed(s)., Springer-Verlag, Berlin, pp. 367-415.

Chipman, D. W., J. Marra, and T. Takahashi (1993). Primary production at $47^{\circ} \mathrm{N}$ and $20^{\circ} \mathrm{W}$ in the North Atlantic Ocean: A comparison between the ${ }^{14} \mathrm{C}$ incubation and the mixed layer carbon budget, Deep Sea Res. Part II, 40: 151-169.

Choi, J. W. , and F. Peters (1992). Effects of temperature on two psychrophilic ecotypes of a heterotrophic nanoflagellate, Paraphysomonas imperforata, Appl. Env. Microbiol., 58: 593-399.

Christian, R. R. , and W. J. Wiebe (1974). The effects of temperature upon the reproduction and respiration of a marine obligate psychrophile., Can. J. Microbiol., 20: 1341-1345.

Cochran, J. K., C. Barnes, D. Achman, and D. Hirschberg (1995). The ${ }^{234}$ Th / ${ }^{238} \mathrm{U}$ disequilibrium as an indicator of scavenging rates and carbon 
fluxes in the Northeast Water Polynya, Greenland, J. Geophys. Res., 100: $4399-4410$.

Codispoti, L. A., G. E. Friederich, R. L. Iverson, and D. W. Hood (1982). Temporal changes in the inorganic carbon system of the south-eastern Bering Sea during spring 1980, Nature, 296: 242-245.

Codispoti, L. A., G. E. Friedrich, and D. W. Hood (1986). Variability in the inorganic carbon system over the southeastern Bering Sea shelf during spring 1980 and spring-summer 1981, Cont. Shelf Res., 5: 133-160.

Codispoti, L. A., G. E. Friedrich, C. M. Sakamoto, and L. I. Gordon (1991). Nutrient cycling and primary production in the marine systems of the Arctic and Antarctic, J. Mar. Syst., 2: 359-384.

Coffin, R. B. (1989). Bacterial uptake of dissolved free and combined amino acids in estuarine waters, Limnol. Oceanogr., 34: 531-542.

Cole, J. J., S. Findlay, and M. L. Pace (1988). Bacterial production in fresh and saltwater ecosystems: a cross-system overview, Mar. Ecol. Prog. Ser., 43: $1-10$.

Cowie, G. L., and J. I. Hedges (1992). Improved amino acid quantification in environmental samples: charge-matched recovery standards and reduced analysis time., Mar. Chem., 37: 223-238.

Cowie, G. L., and J. I. Hedges (1992). Sources and reactivities of amino acids in a coastal marine environment, Limnol. Oceanogr., 37: 703-724.

Dawes, E. A. (1985). Starvation, survival, and energy reserves., in Bacteria in Their Natural Environments , M. Fletcher and G. D. Floodgate, ed(s)., Society for General Microbiology, Academic Press, London, pp. 43-79.

DeLille, D., M. Bouvy, and G. Cahet (1988). Short-term variations of Bacterioplankton in Antarctic Zone: Terre Adelie area, Microb. Ecol., 15: 293-309.

Deming, J., G. Rowe, K. Cochran, I. Walsh, E. Bauerfiend, W. Smith, K. Daly, C. Ashjian, P. Yager, D. Wallace, W. Ritzrau, and G. Graf (1995). Carbon flow in the NEW Polynya: An interdisciplinary view., J. Mar. Syst., in press. 
Deming, J. W. (1985). Bacterial growth in deep-sea sediment trap and boxcore samples, Mar. Ecol. Prog. Ser., 25: 305-312.

Deming, J. W. (1986). Ecological strategies of barophilic bacteria in the deep ocean, Microbiol. Sci., 3: 205-211.

Deming, J. W. (1993). 14C tracer method for measuring microbial activity in deep-sea sediments, in Handbook of Methods in Aquatic Microbial Ecology , P. Kemp, et al., ed(s)., Lewis, Boca Raton, pp. 405-414.

Deming, J. W., and J. A. Baross (1993). The early diagenesis of organic matter: bacterial activity, in Organic Geochemistry, M. Engel and S. Macko, ed(s)., Plenum Press, New York.

Deming, J. W., and J. A. Baross (1994). Survival, Dormancy and nonculturable cells in extreme deep-sea environments, in Non-culturable microorganisms in the environment, R. R. Colwell and D. J. Grimes, ed(s)., Chapman and Hall, New York.

Deming, J. W. , and P. L. Yager (1992). Natural bacterial assemblages in deepsea sediments: towards a global view, Proceedings of the Deep-Sea Food Chains and the Global Carbon Cycle, College Station, TX, G. T. Rowe and V. Pariente, City, 11-27.

Dickson, A. G. (1990). The oceanic carbon dioxide system: Planning for quality data, U.S. JGOFS News, 2(2), U.S. Joint Global Ocean Flux Study Scientific Steering Committee, Woods Hole, MA, pp. 2-10.

Dickson, A.G., and C. Goyet, eds. (1991). Handbook of Methods for the Analysis of the Various Parameters of the Carbon Dioxide System in Seawater, version 1.0, Department of Energy, Washington, DC.

Deibel, D. (1988). Filter feeding by Oikopleura vanhoeffeni: grazing impact on suspended particles in cold ocean waters., Mar. Biol., 99: 177-186.

Ducklow, H. W., and C. A. Carlson (1992). Oceanic bacterial production, in Advances in Microbial Ecology , K. C. Marshall, ed., Plenum Press, New York, pp. 113-181. 
152

Ducklow, H. W., D. A. Purdie, P. J. Le B. Williams, and J. M. Davies (1986). Bacterioplankton: a sink for carbon in a coastal marine plankton community, Science, 232: 865-867.

Dyrssen, D. (1965). A Gran titration of seawater on board Sagitta, Acta Chem. Scand., 19: 1265.

Eccleston-Parry, J. D., and B. S. C. Leadbeater (1994). A comparison of the growth kinetics of six marine heterotrophic nanoflagellates fed with one bacterial species, Mar. Ecol. Progr. Ser., 105: 167-177.

Eppley, R. W. , and B. J. Peterson (1979). Particulate organic matter flux and planktonic new production in the deep ocean, Nature, 282: 677-680.

Erickson, D. J., III (1993). A stability dependent theory for air-sea gas exchange, J. Geophys. Res., 98: 8471-8488.

Evans, G. T., and M. J. R. Fasham (1993). Themes in modeling ocean biogeochemical processes, in Towards a Model of Ocean Biogeochemical Processes, G. T. Evans and M. J. R. Fasham, ed(s)., Springer-Verlag, Berlin, pp. 1-19.

Evans, G. T., and J. S. Parslow (1985). A model of annual plankton cycles. Biol. Oceanogr. 3: 327-347.

Fasham, M. J. R., H. W. Ducklow, and S. M. McKelvie (1990). A nitrogenbased model of plankton dynamics in the oceanic mixed layer., J. Mar. Res., 48: 591-639.

Fasham, M. J. R., J. L. Sarmiento, R. D. Slater, H. W. Ducklow, and R. Williams (1993). Ecosystem behavior at Bermuda Station $S$ and Ocean Weather Station India - A general circulation model and observational analysis., Global Biogeochem. Cycles, 7: 379-415.

Fenchel, T. , and B. J. Finlay (1983). Respiration rates in heterotrophic, freeliving Protozoa, Microb. Ecol., 9: 99-122.

Ferguson, R. L. , and P. Rublee (1975). Contribution of bacteria to standing crop of coastal plankton, Limnol. Oceanogr., 141-145. 
Frost, B. W. (1987). Grazing control of phytoplankton stock in the open subarctic Pacific Ocean: a model assessing the role of mesozooplankton, particularly the large calanoid copepods Neocananus spp., Mar. Ecol. Prog. Ser., 39: 449-68.

Fry, J. C. (1990). Oligotrophs, in Microbiology of Extreme Environments, C. Edwards, ed., McGraw-Hill Publishing Co., New York, pp. 93-116.

Fuhrman, J. (1987). Close coupling between release and uptake of dissolved free amino acids in seawater studied by an isotope dilution approach, Mar. Ecol. Progr. Ser., 37: 45-52.

Geesey, G. G., and R. Y. Morita (1979). Capture of arginine at low concentrations by a marine psychrophilic bacterium, Appl. Env. Microbiol., 38: 1092-1097.

Goldman, J. C., D. A. Caron, and M. R. Dennett (1987). Regulation of gross growth efficiency and ammonium regeneration in bacteria by substrate C:N ratio, Limnol. Oceanogr., 32: 1239-1252.

Goldman, J. C., and P. M. Glibert (1983). Kinetics of inorganic nitrogen uptake by phytoplankton, in Nitrogen in the marine environment, E. J. Carpenter and D. G. Capone, ed(s)., Academic Press, New York, pp. 233274.

Gounot, A. -M. (1991). Bacterial life at low temperatures: physiological and biotechnological implications. J. Appl. Bacteriol., 71: 386-397.

Goyet, C., and A. Poisson (1989). New determination of carbonic acid dissociation constants in seawater as a function of temperature and salinity, Deep Sea Res., Part A, 36: 1635-1654.

Grebmeier, J. M., W. O. Smith, Jr., and R. J. Conover (1995). Biological processes on Arctic continental shelves: ice-ocean-biotic interactions, in Arctic Oceanography: Marginal Ice Zones and Continental Shelves, W. O. Smith, Jr. and J. M. Grebmeier, ed(s)., American Geophysical Union, Washington, DC, pp. 231-261.

Griffiths, P., and I. D. Hill (1985). Applied statistics algorithms. Chichester: Ellis Horwood Limited. 
154

Griffiths, R. P., J. A. Baross, F. J. Hanus, and R. Y. Morita (1974b). Some physical and chemical parameters affecting the formation and retention of glutamate pools in a marine psychrophilic bacterium., Zeit. Allg. Mikrobiol., 14: 359-369.

Griffiths, R. P., B. A. Caldwell, and R. Y. Morita (1984). Observations on microbial percent respiration values in arctic and subarctic marine waters and sediments, Microb. Ecol., 10: 151-164.

Griffiths, R. P., F. J. Hanus, and R. Y. Morita (1974a). The effects of various water-sample treatments on the apparent uptake of glutamic acid by natural marine microbial populations., Can. J. Microbio., 20: 1261-1266.

Griffiths, R. P., S. S. Hayasaka, T. M. McNamara , and R. Y. Morita (1978). Relative microbial activity and bacterial concentrations in water and sediment samples taken in the Beaufort Sea, Can. J. Microbiol., 24: 1217-1226.

Hansen, J. E., A. Lacis, D. Rind, G. Russell, P. Stone, I. Fung, R. Ruedy , and J. Lerner (1984). Climate sensitivity: analysis of feedback mechanisms, in Climate Processes and Climate Sensitivity, J. E. Hansen and T. Takahashi, ed(s)., American Geophysical Union, Washington, DC, pp. 130-163.

Hanson, R. B., D. Shafer, T. Ryan, D. H. Pope, H. K. Lowery (1983). Bacterioplankton in Antarctic Ocean Waters during late austral winter: abundance, frequency of dividing cells, and estimates of production. Appl. Environ. Microbiol. 45: 1622-1632.

Harder, W., and L. Dijkhuizen (1983). Physiological responses to nutrient limitation, Ann. Rev. Microbiol., 37: 1-23.

Heinbokel, J. F. (1978). Studies on the functional role of tintinnids in the Southern California Bight. I. Grazing and growth rates in laboratory cultures., Mar. Biol., 47: 177-189.

Hellebust, J. A. (1965). Excretion of some organic compounds by marine phytoplankton., Limnol. Oceanogr., 10: 192-206.

Hill, P. S. (1992). Reconciling aggregation theory with observed vertical fluxes following phytoplankton blooms, J. Geophys. Res., 997: 2295-2308. 
Hill, P. S., and A. R. M. Nowell (1990). The potential role of large, fast sinking particles in clearing nepheloid layers., Phil. Trans. Royal. Soc. London, Ser. A, 331: 103-117.

Hirche, H. -J., and J. W. Deming (in press). Preface to special issue. J. Marine. Syst.

Hobbie, J. E., and C. C. Crawford (1969). Respiration corrections for bacterial uptake of dissolved organic compounds in natural waters, Limnol. Oceanogr., 14: 528-532.

Hoppe, H.-G., S.-J. Kim, and K. Gocke (1988). Microbial decomposition in aquatic environments: combined process of extracellular enzyme activity and substrate uptake, Appl. Environ. Microbiol., 54: 784-790.

Hoppe, H. G., H. W. Ducklow, and B. Kanasch (1993). Evidence for dependency of bacterial growth on enzymatic hydrolysis of particulate organic matter in the mesopelagic ocean., Mar. Ecol. Prog. Ser., 93: 277283.

Hubberten, U., R. J. Lara , and G. Kattner (1994). Amino acid composition of seawater and dissolved humic substances in the Greenland Sea., Mar. Chem., 45: 121-128.

Huijberts, G. N., G. Eggink, P. de Waard, G. W. Huisman, and B. Witholt (1992). Pseudomonas putida KT2442 cultivated on glucose accumulates poly(3- hydroxyalkanoates) consisting of saturated and unsaturated monomers. (PHA biosynthesis during growth on carbohydrates), Appl. Env. Microbiol., 58: 536-544.

Ingram, W. J., C. A. Wilson, and J. F. B. Mitchell (1989). Modeling climate change: an assessment of sea ice and surface albedo feedbacks, $J$. Geophys. Res., 94: 8609-8622.

Ishida, Y., I. Imai, T. Miyagaki , and H. Kadota (1982). Growth and uptake kinetics of a facultative oligotrophic bacterium at low nutrient concentrations, Microbial Ecol., 8: 23-32.

Jackson, G. A. (1990). A model of the formation of marine algal flocs by physical coagulation processes, Deep Sea Res., 37: 1197-1211. 
Johnson, K. M., P. J. leB. Williams, L. Brändström, and J. M. Sieburth (1987).

Coulometric $\mathrm{TCO}_{2}$ analysis for marine studies: Automation and calibration, Mar. Chem., 21: 117-133.

Johnson, K. M., K. D. Wills, D. B. Butler, W. K. Johnson, and C. S. Wong (1993). Coulometric total carbon dioxide analysis for marine studies: Maximizing the performance of an automated gas extraction system and coulometric detector, Mar. Chem., 44: 167-187.

Jumars, P. A. (1993). Concepts in Biological Oceanography, Oxford University Press, New York, 348 pp.

Jumars, P. A., J. W. Deming, P. S. Hill, L. Karp-Boss, P. L. Yager, and W. B. Dade (1993). Physical constraints on marine osmotrophy in an optimal foraging context, Mar. Microb. Food Webs, 7: 121-159.

Jumars, P. A., D. L. Penry, J. A. Baross, M. J. Perry, and B. W. Frost (1989). Closing the microbial loop: dissolved carbon pathway to heterotrophic bacteria from incomplete ingestion, digestion and absorption in animals, Deep Sea Research, 36: 483-495.

Karl, D. M. (1986). Determination of in situ microbial biomass, viability, metabolism, and growth, in Bacteria in Nature, Vol. 2, Methods and special applications in bacterial ecology, J. S. Poindexter and E. R. Leadbetter, ed(s)., Plenum Press, New York, pp. 85-176.

Karl, D. M. (1993). Microbial processes in the southern oceans, in Antarctic Microbiology, Wiley-Liss, Inc., pp. 1-63.

Karl, D. M., O. Holm-Hansen, G. T. Taylor, G. Tien , and D. F. Bird (1991). Microbial biomass and productivity in the western Bransfield Strait, Antarctica during the 1986-1987 austral summer, Deep-Sea Res., 38: 1029-1055.

Kirchman, D. L. (1993). Leucine incorporation as a measure of biomass production by heterotrophic bacteria. In: Handbook of Methods in Aquatic Microbial Ecology., P. Kemp, B. F. Sherr, E. B. Sherr, J. J. Cole (eds.), Lewis Publishers, Boca Raton, FL. pp 509-512.

Kirchman D. L., S. Y. Newell, R. E. Hodson (1986). Incorporation versus biosysthesis of leucine: Implications for measuring rates of protein 
systhesis and biomass production by bacteria in marine systems. Mar. Ecol. Prog. Ser., 32: 47-59.

Klapper, M. H. (1977). The independent distribution of amino acid near neighbor pairs into polypeptides, Biochem. Biophys. Res. Commun., .78: 1018-1024.

Knox, F. , and M. B. McElroy (1984). Changes in atmospheric $\mathrm{CO}_{2}$ : influence of the marine biota at high latitudes, J Geophys. Res., 89: 4629-4637.

Koch, A. L. (1979). Microbial growth in low concentrations of nutrients, in Strategies of Microbial Life in Extreme Environments, M. Shilo, ed., Verlag Chemie, Weinheim, pp. 341-356.

Kogure, K., U. Simidu, and N. Taga (1979). A tentative direct microscopic method for counting living marine bacteria, Can. J. Microbiol., 25: 415420.

Kottmeier, S. T., and C. W. Sullivan (1988). Sea Ice Microbial Communities (SIMCO), Polar Biol., 8: 293-304.

Kragelund, L., and O. Nybroe (1994). Culturability and expression of outer membrane proteins during carbon, nitrogen, or phosphorus starvation of Pseudomonas fluorescens DF57 and Pseudomonas putida DF14, Appl. Env. Microbiol., 60: 2944-2948.

Kuparinen, J. , and P. K. Bjørnsen (1992a). Bottom-up and top-down controls of the microbial food web in the Southern Ocean: experiments with manipulated microcosms, Polar Biol., 12: 189-195.

Kuparinen, J., and P. K. Bjørnsen (1992b). Spatial distribution of bacterioplankton production across the Weddell-Scotia Confluence during early austral summer 1988-1989, Polar Biol., 12: 197-204.

Lee, S.-H. , and J. A. Fuhrman (1987). Relationships between biovolume and biomass of naturally derived marine bacterioplankton, Appl. Env. Microbiol., 53: 1298-1303.

Legendre, L., and J. Le Fevre (1995). Microbial food webs and the export of biogenic carbon in the oceans. Aquat. Microb. Ecol., 9: 69-77. 
158

Legendre, L., and F. Rassoulzadegan (1994). Continuum of trophic pathways in marine plankton food webs. (2) Consequences. ABSTRACT 1994 Ocean Sciences Meeting, American Geophysical Union/American Society of Limnology and Oceanography, San Diego, CA.

Li, W. K. W., and P. M. Dickie (1987). Temperature characteristics of photosynthetic and heterotrophic activities: seasonal variations in temperate microbial plankton, Appl. Env. Microbiol., 53: 2282-2295.

Linley, E. A. S. , and R. C. Newell (1984). Estimates of bacterial growth yields based on plant detritus, Bull. Mar. Sci., 35: 409-425.

Liss, P. S., and L. Merlivat (1986). Air-sea gas exchange rates: Introduction and synthesis, in The Role of Air-Sea Exchange in Geochemical Cycling, edited by P. Buat-Ménard, D. Reidel, Norwell, Mass., pp. 113127.

Maier-Reimer, E. , and K. Hasselmann (1987). Transport and storage of CO2 in the ocean - an inorganic ocean-circulation carbon cycle model., Climate Dynamics, 2: 63-90.

Matin, A., and H. Veldkamp (1978). Physiological basis of the selective advantage of a Spirillum sp. in a carbon-limited environment., J. Gen. Microbiol, 105: 187-197.

Maynard Smith, J. (1982). Evolution and the Theory of Games, Cambridge University Press, New York, NY, 224 pp.

McLain, D. H. (1974). Drawing contours from arbitrary data points, The Computer J., 17: 318-324.

Meyer-Reil, L.-A. (1978). Autoradiography and epifluorescent microscopy combined for the determination of number and spectrum of actively metabolizing bacteria in natural waters, Appl. Env. Microbiol., 36: 506512 .

Minnett, P. J. (1995). Measurements of the summer surface heat budget of the Northeast Water Polynya in 1992. J. Geophys. Res., 100: 4309-4322. 
Moisan, T., M. Putt , and D. Stoecker (1991). Bacterivory in McMurdo Sound: 2. Information from size-fractionation experiments, Antarctic J. of the U.S., 26: 141-142.

Monod, J. (1942). Recherches sur la croissance des cultures bactériennes. Thesis. Hermann, Paris.

Morgan, P., and C. S. Dow (1986). Bacterial adaptations for growth in low nutrient environments, in Microbes in extreme environments, $R$. A. Herbert and G. A. Codd, ed(s)., Academic Press, London, pp. 187-214.

Morita, R. Y. (1966). Marine psychrophilic bacteria, Oceanogr. Mar. Biol. Ann. Rev., 4: 105-121.

Morita, R. Y. (1975). Psychrophilic bacteria, Bacteriological Rev., 39: 146-167.

Morita, R. Y. (1985). Starvation and miniaturization of heterotrophs, with special emphasis on maintenance of the starved viable state, in Bacteria in Their Natural Environments, M. Fletcher and G. D. Floodgate, ed(s)., Society for General Microbiology, Academic Press, London, pp. 111-130.

Morita, R. Y., R. P. Griffiths, and S. S. Hayasaka (1977). Heterotrophic activity of microorganisms in Antarctic waters. In: G. A. Llano (ed.), Adaptation within Antarctic Ecosystems: Proceedings of the Third SCAR Symposium on Antarctic Biology. Gulf Publishing Co., Houston, TX, pp. 99-113.

Murphy, E., J. Field, B. Kagen, C. Lin, V. Ryabchenko, J. Sarmiento, and J. Steele (1993). Global Extrapolation, in Towards a Model of Ocean Biogeochemical Processes, G. T. Evans and M. J. R. Fasham, ed(s)., Springer-Verlag, Berlin, pp. 21-46.

Najjar, R. G., Sarmiento, J. L., and J. R. Toggweiler (1992). Downward transport and fate of organic matter in the ocean: simulations with a general circulation model. Global Biogeochem. Cycles, 6: 45-76.

Nelson, D. M., J. J. McCarthy, T. M. Joyce, and H. W. Ducklow (1989). Enhanced near-surface nutrient availability and new production resulting from the frictional decay of a Gulf Stream warm-core ring, Deep Sea Res., Part A, 36: 705-714. 
160

NEWater Investigators (1993). Northeast Water Polynya: Polar Sea cruise results, Eos, Trans. Amer. Geophys. Union, 74: 185-196.

Niebauer, H. J., and V. Alexander (1989). Current perspectives on the role of ice margins and polynyas in high-latitude ecosystems. In: L. Rey and V. Alexander, eds., Proceedings of the 6th Conference of the Comite Arctique International. May 1985. E. J. Brill, New York. pp 121-144.

Novitsky, J. A., and R. Y. Morita (1977). Survival of a psychrophilic marine Vibrio under long-term nutrient starvation. Appl. Environ. Microbiol. 33: 635-641.

O'Neill, R. (1971). Function minimization using a simplex procedure. Algorithm AS 47. Applied Statistics, 338.

Overland, J. E., T. B. Curtin, and W. O. Smith, Jr. (1995). Preface to Special Section on Leads and Polynyas, J. Geophys. Res., 100: 4267-4268.

Pace, M. L., and J. J. Cole (1994). Comparative and experimental approaches to top-down and bottom-up regulation of bacteria., Microb. Ecol., 28: 181193.

Pagni, M., T. Beffa, C. Isch, and M. Aragno (1992). Linear growth and poly(beta-hydroxybutyrate) synthesis in response to pulse-wise addition of the growth-limiting substrate to steady-state heterotrophic continuous cultures of Aquaspirillum autotrophicum, J. General Microbiol., 138: 429-436.

Parsons, T. R., M. Takahashi, and B. Hargrave (1984). Biological Oceanographic Processes, $3 d$ edition. Pergamon Press, Oxford, 330 pp.

Pasciak, W. J., and J. Gavis (1974). Transport limitation of nutrient uptake in phytoplankton, Limnol. Oceanogr., 19: 881-888.

Peng, T-H., T. Takahashi, W. S. Broecker, and J. Olafsson (1987). Seasonal variability of carbon dioxide, nutrients and oxygen in the northern North Atlantic surface water: Observations and a model, Tellus, Ser. B, 39B: $439-458$.

Pesant, S., L. Legendre, and M. Gosselin (1995). A typology of ecosystems based on the trophic contribution of size-fractionated phytoplankton: 
the Northeast Water, May to August 1993. ABSTRACT. NEW Symposium, Helsingør, Denmark, 1-5 May, 1995.

Poisson, A., and C.-T.-A. Chen (1987). Why is there little anthropogenic $\mathrm{CO}_{2}$ in the Antarctic Bottom Water?, Deep Sea Res., Part A, 34: 1255-1275.

Pomeroy, L. R. (1974). The ocean's food web: a changing paradigm. BioScience, 24: 499-504.

Pomeroy, L. R., G. Cota, and W. J. Wiebe (1995). Arctic primary and secondary productivity: where and by whom?, Proceedings of the Northeast Water Polynya Symposium, Helsingør, Denmark, City, 86.

Pomeroy, L. R., and D. Deibel (1986). Temperature regulation of bacterial activity, Science, 233: 359-360.

Pomeroy, L. R., S. A. Macko, P. H. Ostrom, and J. Dunphy (1990). The microbial food web in Arctic seawater: concentration of dissolved free amino acids and bacterial abundance and activity in the Arctic Ocean and in Resolute Passage, Mar. Ecol. Progr. Ser., 61: 31-40.

Pomeroy, L. R., and W. J. Wiebe (1988). Energetics of microbial food webs, Hydrobiologia, 159: 7-18.

Pomeroy, L. R., and W. J. Wiebe (1993). Energy sources for microbial food webs, Mar. Microb. Food Webs, 7: 101-118.

Pomeroy, L. R., W. J. Wiebe, and D. Deibel (1991). Bacterial responses to temperature and substrate concentration during the Newfoundland spring bloom., Mar. Ecol. Progr. Ser., 75: 143.

Pomeroy, L. R., W. J. Wiebe, D. Deibel, R. J. Thompson, G. T. Rowe , and J. D. Pakulski (1991). Bacterial responses to temperature and substrate concentration during the Newfoundland spring bloom, Mar. Ecol. Prog. Ser., 75: 143-159.

Porter, J. R. (1946). Bacterial Chemistry and Physiology, Chapman and Hall, London, pp. 1073. 
162

Press, W. H., B. P. Flannery, S. A. Teukolsky, and W. T. Vetterling (1989). Numerical Recipes; The Art of Scientific Computing (FORTRAN version), Cambridge University Press, New York, pp. 254-259.

Putt, M., D. K. Stoecker, and J. Altstatt (1991). Bacterivory in McMurdo Sound: 1. Grazing by heterotrophic nanoflagellates, Antarctic J. of the U.S., 26: 139-140.

Quay, P.D., B. Tilbrook, and C. S. Wong (1992). Oceanic uptake of fossil fuel $\mathrm{CO}_{2}$ : Carbon-13 evidence, Science, 256: 74-79.

Ramsay, B. A., I. Saracovan, J. A. Ramsay, and R. H. Marchessault (1992). Effect of nitrogen limitation on long-side-chain Poly- $B$ hydroxyalkanoate synthesis by Pseudomonas resinovorans., Appl. Env. Microbiol, 58: 744-746.

Redfield, A. C., B. H. Ketchum, and F. A. Richards (1963). The influence of organisms on the composition of sea-water, in The composition of Seawater; comparative and descriptive oceanography, M. N. Hill, ed., Interscience Publishers, John Wiley \& Sons, New York, pp. 26-77.

Reichardt, W. (1991). Ecological and potential biotechnological significance of marine psychrophilic bacteria, Current Topics in Mar. Biotech., 65-68.

Relexans, J. -C., J. Deming, A Dinet, J. -F. Gaillard, and M. Sibuet (in press). Sedimentary organic matter and micro-meiobenthos with relation to trophic conditions in the Northeast Tropical Atlantic. Deep-Sea Res.

Rivkin, R. B., M. R. Anderson, and J. D E Gustafson (1991). Dynamics of bacterioplankton growth in McMurdo Sound, Antarctica: evidence for substrate sufficient growth., Antarctic J., 1991 Review: 145-146.

Rivkin, R. B., P. L. J. Matthews, C. LeDrew (1994). Microbial processes in high Arctic marine communities. 2. Bacterioplankton growth. ABSTRACT 1994 Ocean Sciences Meeting, American Geophysical Union/American Society of Limnology and Oceanography, San Diego, CA.

Robarts, R. D., L. M. Sephton, and R. J. Wicks (1991). Labile dissolved organic carbon and water temperature as regulators of heterotrophic bacterial activity and production in the lakes of Sub-Antarctic Marion Island, Polar Biol., 11: 403-413. 
Russell, N. J. (1990). Cold adaptation in bacteria. Phil. Trans. R. Soc. London, B 326: 595-611.

Sakshaug, E. (1989). The physiological ecology of polar phytoplankton, in Proceedings of the Sixth Conference of the Comite Arctique Internationale 13-15 May 1985, edited by L.R. Rey and V. Alexander, Brill, Leiden, pp. 61-89.

Sambrotto, R. N., G. Savidge, C. Robinson, P. Boyd, T. Takahashi, D. M. Karl, C. Langdon, D. Chipman, J. Marra, and L. Codispoti (1993). Elevated consumption of carbon relative to nitrogen in the surface ocean, Nature, 363: 248-250.

Sarmiento, J. L., M. J. R. Fasham, R. D. Slater, J. R. Toggweiler, and H. Ducklow (1989). The role of biology in the chemistry of $\mathrm{CO} 2$ in the ocean, in Chemistry of the Greenhouse Effect, M. Farrell, ed., Lewis Publishing, New York.

Sarmiento, J. L., R. D. Slater, M. J. R. Fasham, H. W. Ducklow, J. R. Toggweiler , and G. T. Evans (1993). A seasonal, 3-dimensional ecosystem model of nitrogen cycling in the North Atlantic Euphotic Zone, Global Biogeochem. Cycles, 7: 417-450.

Sarmiento, J. L., J. R. Toggweiler, and R. Najjar (1988). Ocean carbon-cycle dynamics and atmospheric CO2, Phil. Trans. R. Soc. London, 325: 3-21.

Sarmiento, J. L. , and R. Toggweiler (1984). A new model for the role of the oceans in determining atmospheric PCO2, Nature, 308: 621-624.

Schneider, W., and G. Budéus (1994). The North East Water polynya (Greenland Sea), I., A physical concept of its generation, Polar Biol., 14: $1-9$.

Shimeta, J. (1993). Diffusional encounter of submicrometer particles and small cells by suspension feeders, Limnol. Oceanogr., 38: 456-465.

Shimeta, J., P. A. Jumars, and E. J. Lessard (1995). Influence of turbulence on suspension feeding by planktonic protozoa; experiments in laminar shear fields, Limnol. Oceanogr., 40: 845-859. 
164

Siegenthaler, U., and J. L. Sarmiento (1993). Atmospheric carbon dioxide and the ocean., Nature., 365: 119-125.

Siegenthaler, U. , and T. Wenk (1984). Rapid atmospheric CO2 variations and ocean circulation, Nature, 308: 624-626.

Simon, M., and F. Azam (1989). Protein content and protein synthesis rates of planktonic marine bacteria. Mar. Ecol. Prog. Ser., 51: 201-

Slater, R. D., J. L. Sarmiento, and M. J. R. Fasham (1993). Some parametric and structural simulations with a three-dimensional ecosystem model of nitrogen cycling in the North Atlantic euphotic zone, in Towards a Model of Ocean Biogeochemical Processes, G. T. Evans and M. J. R. Fasham, ed(s)., Springer-Verlag, Berlin, pp. 261-294.

Smith, R. E. H., P. Clement, and G. F. Cota (1989). Population dynamics of bacteria in sea ice, Microb. Ecol., 17: 63-76.

Smith, S. V., and J. T. Hollibaugh (1993). Coastal metabolism and the oceanic organic carbon balance, Rev. Geophys., 31: 75-89.

Smith, S. V., and F. T. Mackenzie (1991). Comments on the role of oceanic biota as a sink for anthropogenic $\mathrm{CO}_{2}$ emissions, Global Biogeochem. Cycles, 5: 189-190.

Smith, W. O., Jr. (1995). Primary productivity and new production in the Northeast Water (Greenland) Polynya during summer 1992, J. Geophys. Res. 100: 4357-4370.

Smith, W. O., Jr., L. A. Codispoti, D. M. Nelson, T. Manley, E. J. Buskey, H. J. Niebauer, and G. F. Cota (1991). Importance of Phaeocystis blooms in the high-latitude ocean carbon cycle, Nature, 352: 514-516.

Smith, W. O., Jr., J. Goering, J. Grebmeier, S. Smith, and B. Ward (1990). Productivity in the Arctic and response to global change, Proceedings of the Arctic System Science Ocean/Atmosphere/Ice Interactions Workshop, Lake Arrowhead, CA, R. E. Moritz, et al., City, 113-132.

Smith, W. O., Jr., M. Gosselin, and L. Legendre (1995). New Production in the Northeast Water Polynya: 1993, J. Mar. Syst., in press. 
Smith, W. O., Jr., and E. Sakshaug (1990). Polar phytoplankton, in Polar Oceanography, Part B: Chemistry, Biology and Geology, edited by W. O. Smith Jr., Academic, San Diego, Calif., pp. 477-525.

Smith, W. O., Jr., I. D. Walsh, B. C. Booth , and J. W. Deming (1995). Particulate matter and phytoplankton and bacterial biomass distributions in the Northeast Water Polynya during summer 1992, J. Geophys. Res., 100: 4341-4356.

Sokal, R. R., and F. J. Rohlf (1981). Biometry , W.H. Freeman and Company, New York, pp 547-555.

Solomons, T. W. G. (1988). Organic Chemistry, John Wiley \& Sons, New York, $1186 \mathrm{pp}$.

Stephens, D. W., and J. R. Krebs (1986). Foraging Theory , Princeton University Press, Princeton, NJ, 247 pp.

Subba Rao, D. V., and T. Platt (1984). Primary production of Arctic waters, Polar Biol., 3: 191-201.

Sullivan, C. W., G. F. Cota, D. W. Krempin, and W. O. Smith, Jr. (1990). Distribution and activity of bacterioplankton in the marginal ice zone of the Weddell-Scotia Sea during austral spring, Mar. Ecol. Prog. Ser., 63: 239-252.

Sullivan, C. W., C. R. McClain, J. C. Comiso, and W. O. Smith, Jr. (1988). Phytoplankton standing crops within an Antarctic ice edge assessed by satellite remote sensing, J. Geophys. Res., 93: 12,487-12,498.

Sverdrup, H. U. (1953). On conditions for the vernal blooming of phytoplankton, J. Cons. Cons. Int. Explor. Mer, 18: 287-295.

SYSTAT (1992). Statistics, Version 5.2 Edition, SYSTAT, Inc., Evanston, $\mathrm{IL}$, 724 pp.

Takahashi, T., W. S. Broecker, and S. Langer (1985). Redfield ratio based on chemical data from isopycnal surfaces, J. Geophys. Res., 90: 6907-6924.

Takahashi, T., J. Olafsson, J. G. Goddard, D. W. Chipman, and S. C. Sutherland (1993). Seasonal variation of $\mathrm{CO}_{2}$ and nutrients in the high-latitude 
surface oceans: A comparative study, Global Biogeochem. Cycles, 7: 843-878.

Tan, F. C., D. Dyrssen, and P. M. Strain (1983). Sea-ice meltwater and excess alkalinity in the East Greenland Current, Oceanol. Acta, 6: 283-288.

Tans, P. P., I. Y. Fung, and T. Takahashi (1990). Observational constraints on the global atmospheric CO2 budget, Science, 247: 1431-1438.

Taylor, A. H., A. J. Watson, M. Ainsworth, J. E. Robertson, D. R. Turner (1991). A modeling investigation of the role of phytoplankton in the balance of carbon at the surface of the North Atlantic. Global Biogeochem. Cycles, 5: 151-171.

Theil, H., O. Pfannkuche, G. Shriver, K. Lochte, A. J. Gooday, C. Hembleben, R. F. C. Mantoura, C. M. Turley, J. W. Patching, and F. Riemann (1988). Phytodetritus on the deep-sea floor in a central oceanic region of the Northeast Atlantic, Biol. Oceanogr., 6: 203-239.

Thimann, K. V. (1963). The Life of Bacteria. Their growth, metabolism, and relationships, 2nd edition, The Macmillan Co., New York, 909 pp.

Thingstad, T. F. , and I. Martinussen (1991). Are bacteria active in the cold pelagic ecosystem of the Barents Sea?, Polar Res., 10: 2255-266.

Thompson, B. , and R. D. Hamilton (1974). Some problems with the heterotrophic-uptake methodology, in Effect of the Ocean Environment on Microbial Activity, R. R. Colwell and R. Y. Morita, ed(s)., University Park Press, Baltimore, MD, pp. 566-575.

Toggweiler, J. R. (1993). Carbon overconsumption, Nature, 363: 210-211.

Toggweiler, J. R., K. Dixon , and K. Bryan (1989). Simulations of radiocarbon in a coarse-resolution world ocean model, 1. Steady state pre-bomb distributions., J. Geophys. Res., 94: 8217-8242.

Top, Z. (1994). Tritium and Helium Measurements in the North East Greenland Polynya. ABSTRACT 1994 Ocean Sciences Meeting, American Geophysical Union/American Society of Limnology and Oceanography, San Diego, CA. 
Tremaine, S. C. , and A. L. Mills (1987). Tests of the critical assumptions of the dilution method for estimating bacterivory by microeucaryotes, Appl. Environ. Microbiol. , 53: 2914-2921.

Vetter, Y. -A., and J. W. Deming (1995). Extracellular enzyme activity in the Arctic NEW polynya, Mar. Ecol. Prog. Ser. , 114: 23-34.

Wallace, D. W. R., T. S. Hopkins, W. J. Behrens, J. Deming, C. Kinder, W. O. Smith, Jr., Z. Top, and I. D. Walsh (1995a). Collaborative research on the Northeast Water Polynya: Hydrographic data report. USCGC Polar Sea Cruise, July 15-August 15, 1992, informal report, Brookhaven Natl. Lab., Upton, NY

Wallace, D. W. R., T. S. Hopkins, W. J. Behrens, F. Bignami, J. Deming, C. Kinder, Y. Shi, W. O. Smith Jr., Z. Top, and I. D. Walsh (1995b). Collaborative research on the Northeast Water Polynya: Hydrographic data report. USCGC Polar Sea Cruise, July 15-August 15, 1992, informal report, Brookhaven Natl. Lab., Upton, NY

Wallace, D. W. R., P. J. Minnett, and T. S. Hopkins (1995c). Nutrients, oxygen, and inferred new production in the Northeast Water Polynya, 1992, J. Geophys. Res., 100: 4323-4340.

Wallace, D. W. R., R. M. Moore, and E. P. Jones (1987). Ventilation of the Arctic Ocean cold halocline: Rates of diapycnal and isopycnal transport, oxygen utilization, and primary production inferred using chlorofluoromethane distributions, Deep Sea Res., Part A, 34: 19571979.

Walsh, J. J. (1989). Arctic carbon sinks: Present and future, Global Biogeochem. Cycles, 3: 393-411.

Walsh, J. J., et al. (1989). Carbon and nitrogen cycling within the Bering/Chukchi Seas: Source regions for organic matter effecting AOU demands of the Arctic Ocean, Prog. Oceanogr., 22: 277-359.

Wassman, P., M. Vernet, B. G. Mitchell, and F. Rey (1990). Mass sedimentation of Phaeocystis pouchetii in the Barents Sea, Mar. Ecol. Prog. Ser., 66: 183-195. 
Weiss, R.F. (1974). Carbon dioxide in water and seawater: The solubility of a non-ideal gas, Mar. Chem., 2: 203-215.

Wicks, R. J., and R. D. Robarts (1987). The extraction and purification of DNA-labeled with [methyl- ${ }^{3} \mathrm{H}$ ] thymidine in aquatic bacterial production studies. J. Plankton. Res., 9: 1159-1166.

Wiebe, W. J. , and L. R. Pomeroy (1991). Possible effects of global warming on marine foodwebs at low temperature., in The Unity of Evolutionary Biology, Proc. 4th Int. Congr. Systematic and Evolutionary Biology. , E. C. Dudley, ed.

Wiebe, W. J., J. W M Sheldon, and L. R. Pomeroy (1992). Bacterial growth in the cold: evidence for an enhanced substrate requirement, Appl. Env. Microbiol., 58: 359-364.

Wiebe, W. J., J. W M Sheldon, and L. R. Pomeroy (1993). Evidence for an enhanced substrate requirement by marine mesophilic bacterial isolates at minimal growth temperatures, Microb. Ecol., 25: 151-159.

Wilkenson, L. (1975). REGM: A multivariate general linear hypothesis program for least squares analysis of multivariate data. Behavior Research Methods and Instrumentation, 7: 485-486.

Wilkenson, L. (1980). REGM: A multivariate general linear hypothesis program. American Statistician, 34: 182.

Wilson, C. A. and J. F. B. Mitchell (1987). A doubled $\mathrm{CO}_{2}$ climate sensitivity experiment with a global climate model including a simple ocean, $J$. Geophys. Res., 92: 13,315-13,343.

Wright, R. T. , and J. E. Hobbie (1966). Use of glucose and acetate by bacteria and algae in aquatic ecosystems., Ecology, 47: 447-464.

Yager, P. L., and J. W. Deming (1993). Collaborative research in the Northeast Water Polynya: Temperature and substrate effects on pelagic bacterial kinetics, paper presented at the Oceanography Society Annual meeting, Seattle, Wash.

Yager, P. L., D. W. R. Wallace, K. M. Johnson, W. O. Smith, Jr., P. J. Minnett , and J. W. Deming (1995). The Northeast Water Polynya as an 
atmospheric $\mathrm{CO}_{2}$ sink: a seasonal rectification hypothesis, J. Geophys. Res., 100: 4389-4398.

Yamazaki, H. , and T. R. Osborn (1988). Review of oceanic turbulence: implications for biodynamics, in Toward a Theory on BiologicalPhysical Interactions in the World Ocean. B. J. Rothschild (ed.), Kluwer, pp. 215-234.

Zobell, C. E. (1946). Marine Microbiology, A monograph on hydrobacteriology. Chronica Botanica Co., Waltham, MA. 240 pp. 


\section{APPENDIX 1: DERIVATION OF EQUATION III-1}

Start with the Michaelis-Menton uptake equation which describes utilization rate, $v$, as a function of substrate concentration at the cell surface, $C_{0}$ :

$$
v=\frac{V_{\max } \cdot C_{o}}{K_{t}+C_{o}}
$$

and assuming steady state at the cell membrane, set the diffusive flux to the cell equal to the kinetic uptake of substrate by the cell:

$$
v=\frac{V_{\max } \cdot C_{o}}{K_{m}+C_{o}}=J_{D}=4 \pi \cdot r_{o} \cdot D \cdot\left(C_{\infty}-C_{o}\right)
$$

Rearrange to put in the form of a quadratic equation to solve:

$$
C_{o}^{2}+\left[\frac{V_{\max }}{4 \pi \cdot r_{o} D}+K_{m}-C_{\infty}\right] C_{o}-C_{\infty} K_{m}=0
$$

and then solve for $\mathrm{C}_{0}$ :

$$
C_{o}=\frac{1}{2}\left[C_{\infty}-K_{m}-\frac{V_{\max }}{4 \pi \cdot r_{o} D} \pm \sqrt{\left(\frac{V_{\max }}{4 \pi \cdot r_{o} D}+K_{m}-C_{\infty}\right)^{2}+4 C_{\infty} K_{m}}\right]
$$

Substitute Eq. 4 into Eq. 1 to obtain a complete, albeit complex, equation to which the data can be fit:

$$
v=\frac{V_{\max }}{\left\{1+\left(\frac{2 * K_{m}}{\left.C_{\infty}-K_{m}-\frac{V_{\max }}{4 \pi r_{0} D}+\sqrt{\left(\frac{V_{\max }}{4 \pi r_{0} D}+K_{m}-C_{\infty}\right)^{2}+4 C_{\infty} K_{m}}\right)}\right)\right.}
$$




\section{Patricia L. Yager}

\section{BORN}

May 28, 1963 Robert D. and Janet L. Yager, parents

Sacramento, California

\section{MARRIED}

July 14, 1991 Steven M. Holland,

Seattle, Washington

\section{EDUCATION}

1991-1996 University of Washington, School of Oceanography, Seattle, Washington. Doctor of Philosophy. Advisor: J. W. Deming. Dissertation: The Microbial Fate of Carbon in High-Latitude Oceans: Impact of the Microbial loop on Oceanic Uptake of $\mathrm{CO}_{2}$.

1985-1988 University of Washington, School of Oceanography, Seattle, Washington. Master of Science. Advisor: A. R. M. Nowell. Masters Thesis: Enhanced Deposition to Pits: the Effect of Microtopography on Food Sources for Benthic Organisms.

1981-1985 Brown University, Department of Geology, Providence, Rhode Island. Bachelor of Science, Sigma Xi. Advisor: W. L. Prell. Undergraduate Thesis: Sediment Distribution in Hundred Acre Cove and its Use as a Key to Estuarine Circulation and Sediment Transport.

1978-1981 Mercer Island High School, Mercer Island; Washington.

\section{ADDITIONAL EDUCATION}

1994

1992, 1993

1991-1992
NASA-NOAA-JPL Summer School for Earth Sciences, California Institute of Technology, Pasadena, California. Course: Processes of Global Change. Drs. S. K. Ride and D. J. McCleese, coordinators.

Research practicum (DOE fellowship program), Brookhaven National Laboratory, Ocean and Atmospheric Sciences Division, Department of Applied Science, Upton, New York. Instruction and sample analysis using SOMMA total inorganic carbon analyzer (Dr. D. W. R. Wallace and $\mathrm{K}$. Johnson) and closed-cell potentiometric titration alkalinity system (Dr. C. Goyet, Woods Hole Oceanographic Institute, Woods Hole, Massachusetts).

Institute of Ecology and Department of Microbiology, University of Georgia, Athens, Georgia. Courses in Microbial Ecology, Microbiology, and Biochemistry. Drs. Hodson, Pomeroy, Moran, Wiebe, Whitman, Shimkets, Wiegel, Dailey, and others. 
Friday Harbor Marine Laboratories, University of Washington, Friday Harbor, Washington. Summer course: Climate and the Marine Biosphere. Dr. R. H. Gammon and others. Harbor, Washington. Summer course: Polychaetes. Drs. K. Fauchald, S. Woodin, and H. Wilson.

Friday Harbor Marine Laboratories, University of Washington, Friday Harbor, Washington. Summer course: Biological Sedimentary Dynamics. Drs. A. R. M. Nowell, P. A. Jumars, and R. C. Aller.

1984 S.E.P.M. Short Course, Geological Society of America, Providence, Rhode Island. Course: Mechanics of Sediment Movement. Drs. G. V. Middleton and J. B. Southard.

1984 Department of Geology, Brown University, Providence, Rhode Island. Micropaleontology Short Course in Benthic Foraminifera. Dr. W. A. Berggren.

1983 Friday Harbor Marine Laboratories, University of Washington, Friday Harbor, Washington. Summer courses: Marine Invertebrate Zoology (Drs. E. Kozloff and T. Suchanek), Comparative Invertebrate Embryology (Dr. A. Whiteley).

\section{Professional EXPERIENCE}

1989 - 1991 Research scientist (Oceanographer I, II). Laboratory and research cruise technician for Dr. J. W. Deming, University of Washington, Seattle, Washington. Microbial oceanography, experimental design and execution, methods development, data analysis, data presentation, training of undergraduate and graduate students.

1988

Teaching Assistant for Dr. A. Duxbury, Introductory Oceanography; lecture and laboratory.

1987 Teaching assistant for Dr. C. M. Emerick, Introductory Oceanography; included laboratory exercise development resulting in published course workbook (Introduction to the Oceans, a Laboratory Manual, Kendall/Hunt Pub., 1991).

1986 Teaching Assistant for Drs. A. R. M. Nowell and P. A. Jumars. Friday Harbor Laboratories, University of Washington, Friday Harbor, Washington. Dynamics at the Sediment-Water Interface, lecture, laboratory, and fieldwork.

\section{AWARDS \& HONORS} Postdoctoral Fellowship in Ocean Modeling. Start date: March 1996. Research. 


\section{FIELD EXPERIENCE}

1992, 1993 Research cruises to Northeast Water (NEW) Polynya (77-81N, 6$\left.17^{\circ} \mathrm{W}\right)$, aboard Coast Guard icebreaker USCGC Polar Sea, July August 1992, 1993. Temperature and substrate effects on pelagic microbial utilization and efficiency, inorganic carbon depletion associated with biological activity, part of an interdisciplinary research team studying carbon cycling in Arctic polynyas.

1993

Research cruise to NEW Polynya, aboard German icebreaker FS Polarstern, May 16 - June 24. Collaboration with Canadian research team studying microbial loop processes in Arctic polynyas, part of International NEW project.

1991 Research cruise to Santa Catalina Basin, California, aboard RV Atlantis II and DSRV Alvin. Effects of whale carcass eutrophication on deep-sea benthic microbial community.

1990 Research cruise to Norwegian Sea, aboard German research vessel, FS Meteor. Effects of pressure and temperature on deep-sea benthic microbial processes. Collaborated with Drs. G. Graf and L. A. Meyer-Reil.

1987, 1988 Hydrodynamics Laboratory, Friday Harbor Laboratories, San Juan Island, Washington. Masters Thesis research: Experiments using race-track, straight-through, and annular flumes to study effect of biogenic microtopography on deposition of particles.

1987 Research Platform in Santa Catalina Basin, California. Using Remote Underwater Manipulator (RUM II). Deep-sea biological-sedimentary interactions, deployment of benthic pit mimic.

1987 Research cruise to Santa Catalina Basin, California, aboard RV Atlantis II and DSRV Alvin. Deep-sea biological-sedimentary interactions, deployment of benthic pit mimic.

1986 Research cruise to California continental shelf, aboard RV Thomas G. Thompson. STRESS project: examined sediment transport and storm effects on continental shelf and slope with side-scan sonar and boxcoring.

1985 Fieldwork using canoe and motorized raft. Hundred Acre Cove, Barrington, Rhode Island. Undergraduate Research Project: collected estuarine benthic samples using grabs and corers for sediment analysis and hydrodynamics study.

1984 Intertidal fieldwork. False Bay, San Juan Island, Washington. Effect of biogenic roughness height and density on local erosion and deposition. 
174

\section{PUBLICATIONS}

Yager, P. L., D. W. R. Wallace, K. M. Johnson, W. O. Smith Jr., P. J. Minnett, and J. W. Deming (1995). The Northeast Water Polynya as an atmospheric $\mathrm{CO}_{2}$ sink; a seasonal rectification hypothesis. Journal of Geophysical Research, 100: 4389-4398.

Jumars, P. A., J. W. Deming, P. S. Hill, L. Karp-Boss, P. L. Yager, and W. B. Dade (1993). Physical constraints on marine osmotrophy in an optimal foraging context. Marine Microbial Food Webs, 7: 121-159.

Yager, P. L. , A. R. M. Nowell, and P.A. Jumars (1993). Enhanced deposition to pits: a local food source for benthos. Journal of Marine Research 51: 1-28.

Deming, J. W. and P. L. Yager (1992). Natural bacterial assemblages in deep-sea sediments: towards a global view. In: G. T. Rowe and V. Pariente (eds.), Deep-Sea Food Chains and the Global Carbon Cycle. Kluwer Academic Publishers, Netherlands, pp. 11-27.

Abstracts:

Yager, P. L., and J. W. Deming (1996). Microbial activity in the Northeast Water Polynya: testing for temperature and substrate effects using a kinetic approach. 1996 Ocean Sciences Meeting, American Geophysical Union / American Society of Limnology and Oceanography, San Diego, February 1996.

Yager, P. L., J. W. Deming, T. Sime-Ngando, and K. Juniper (1995). Pelagic microbial activity in the Northeast Water Polynya: Implications for the inorganic carbon cycle. International Northeast Water Polynya Symposium, Helsingør, Denmark, May 1995.

Yager, P. L. and J. W. Deming (1993). Collaborative research in the Northeast Water Polynya: temperature and substrate effects on pelagic bacterial kinetics. Annual meeting, The Oceanography Society, Seattle, April 1993.

Yager, P. L., D. W. R. Wallace, and K. M. Johnson (1993). Collaborative research on the Northeast Water Polynya: inorganic carbon parameters and uptake of atmospheric $\mathrm{CO}_{2}$. Annual meeting, The Oceanography Society, Seattle, April 1993.

Yager, P. L. and J. W. Deming (1993). Collaborative research on the Northeast Water polynya (U.S. NEW 1992): Pelagic Microbial Dynamics. International Workshop on Arctic Polynyas, Seattle, January 1993.

Deming, J. W. and P. L. Yager (1991). Benthic bacterial populations in the Greenland Sea corridor: response to increased carbon flux and temperature. Arctic OceanAtmosphere-Ice Interactions in Global Change. Fall meeting, American Geophysical Union, San Francisco, December 1991.

Yager, P. L., A. R. M. Nowell, and P. A. Jumars (1989). Enhanced deposition to pits: the effect of microtopography on food sources for deposit feeders. Annual meeting, North American Benthological Society, Guelph, Ontario, May 1989. 
M97053630

Inim in In

Report Number (14) DOE/OR/OO033 - T753

Publ. Date (11) $\frac{1996}{\text { Sponsor Code (18) }} \frac{\text { DOER, XF }}{U C-4 O O, D E}$

UC Category (19) UC-400, DDE/ER

DOE 